\title{
23. BIOSTRATIGRAPHIC SUMMARY FOR LEG 138
}

\author{
N.J. Shackleton, ${ }^{2}$ J.G. Baldauf, ${ }^{3}$ J.-A. Flores ${ }^{4}$ M. Iwai, ${ }^{5}$ T.C. Moore, Jr., ${ }^{6}$ I. Raffi, ${ }^{7}$ and E. Vincent ${ }^{8}$
}

\begin{abstract}
The sediments recovered during Leg 138 have provided us with a remarkable opportunity to improve the stratigraphic framework for east-central Pacific Ocean Neogene age sediments. In this chapter, we review some of the data that have been generated and derive best estimates for the ages of potentially useful biostratigraphic datums, within the paleomagnetic temporal framework of Shackleton et al. determined for this volume and also, for comparison, according to the 1985 and 1992 paleomagnetic time scales of Berggren et al. and Cande and Kent, respectively.
\end{abstract}

\section{INTRODUCTION}

Despite advances in magnetostratigraphy, stable isotope stratigraphy and various manifestations of cyclostratigraphy, it is still true that biostratigraphy is the essential tool by which the geological evidence for environmental changes is put into a temporal framework. Advances in biostratigraphy and in other tools for stratigraphic correlation go hand in hand, and, in this chapter, we link the multiple stratigraphic and geochronological efforts that have been devoted to Leg 138 sediments with a view to further improvements in the basis of Neogene biostratigraphy and biochronology.

Remarkably high resolution was achieved in the shipboard biostratigraphies for all the major microfossil groups examined (Mayer, Pisias, Janecek, et al., 1992). Moreover, considerable further advances have been made in the ensuing months. Detailed descriptions of the biostratigraphy of the eleven sites cored during Leg 138 are given elsewhere: Baldauf and Iwai (this volume) for diatoms; Raffi and Flores (this volume) for nannofossils; Moore (this volume) for radiolarians; Vincent and Toumarkine (this volume) for Miocene foraminifers; Shackleton, Hall, and Pate (this volume) for foraminifers in Site 846. Raffi et al. (this volume) have also reviewed and synthesized the nannofossil biostratigraphy. In this chapter, we discuss the data primarily in relation to the reliability of, and improved age calibrations of, a large number of biostratigraphic datum levels. The locations of the Leg 138 sites and of others discussed in the text are given in Table 1 .

Shipboard work was conducted using calibrations based on the summaries by Berggren et al. (1985b). Much of the information for Pacific sediments was summarized by Barron et al. (1985a) in a review that was largely based on the successes of Deep Sea Drilling Project (DSDP) Leg 85 (Pisias et al., 1985; Barron et al., 1985b).

' Pisias, N.G., Mayer, L.A., Janecek, T.R., Palmer-Julson, A., and van Andel, T.H (Eds.), 1995. Proc. ODP, Sci. Results, 138: College Station, TX (Ocean Drilling Program).

${ }^{2}$ Subdepartment of Quaternary Research, Godwin Laboratory, University of Cambridge, Free School Lane, Cambridge, CB2 3RS, United Kingdom.

${ }^{3}$ Ocean Drilling Program, Texas A\&M University, 1000 Discovery Drive, College Station. TX 77845, U.S.A.

${ }^{4}$ Universidad de Salamanca, Departmento de Geologia, S-37008 Salamanca, Spain.

${ }^{5}$ Institute of Geology and Paleontology, Faculty of Science, Tohoku University, Aobayama, Aoba-ku, Sendai 980, Japan.

${ }^{6}$ Center for Great Lakes and Aquatic Sciences, University of Michigan, 2200 Bonisteel Boulevard, Ann Arbor, MI 48109-2099, U.S.A.

'Università degli Studi "G. D'Annunzio," Facoltà di Scienze Matematiche, Fisiche e Naturli, Castelgandolfo, Italy 00040.

${ }^{8}$ Laboratoire de Géologie du Quaternaire, CNRS-Luminy, Case 907. 13288 Marseille Cedex 9, France.

\section{TIME SCALE}

The calibrations attempted here are possible in part because age models that were developed for the sites (Shackleton et al., this volume) were independent of the biostratigraphy to a large extent. These age models originated from an astronomical calibration of GRAPE density cycles through the entire Pliocene. Because several sites have good magnetic polarity records, this enabled the Pliocene magnetic polarity sequence to be dated astronomically, confirming the pioneering work of Hilgen (1991a, 1991b). This calibration, together with a new radiometric date for the top of C5n obtained by Baksi (1992, 1993), was used to put a new age calibration on the revised polarity sequence compiled by Cande and Kent (1992). Table 2 gives the complete polarity time scale of Shackleton et al. (this volume), henceforth, SCHPS94. The age models developed for each site are very detailed because they entailed correlating individual GRAPE density maxima and minima to insolation maxima and minima; they are listed as Tables 1 to 11 in Shackleton et al. (this volume).

Reliable magnetostratigraphy was obtained for major segments of the polarity scale in several sites, as follows: in Site 844, from the Brunhes to C5n; in Site 845, from the Gauss to C5ABn; in Site 848, from the Brunhes to the Gilbert and from C4 to C5n; in Site 850, from the basal Matuyama to the uppermost Gilbert; in Site 851, from the Brunhes to the Cochiti; in Site 852, from the Brunhes to C3A and from C4A to C5n; in Site 853, from the Brunhes to C4; and in Site 854, from the Brunhes to C5n. Details are given in the site chapters in Mayer, Pisias, Janecek, et al. (1992), but it should be noted that part of the record of Site 844 has been reinterpreted by Schneider (this volume), who also provided additional data from Site 845. Despite this broad coverage, we think that, for the section younger than about $10 \mathrm{Ma}$, the reliability of the intersite correlations based on GRAPE density fluctuations is so good that datum age estimates should be based on all sites rather than being based primarily on those sites that preserve a magnetostratigraphic record. From that point to the base of the magnetostratigraphic record of Site 845 , we consider estimates based on Site 845 to be the most reliable.

The upper and lower depth limit of each datum (mcd) in each site is given in Table 3 (complete table on CD-ROM, back pocket), which summarizes data in the individual chapters referred to above. We have obtained the ages of the upper and lower limits defining each datum in each site, using the age models given in Tables 1 to 11 in Shackleton et al. (this volume); these are given in Table 4 . In Table 5 (complete table on CD-ROM, back pocket), all the estimates for each datum are sorted by age. This provides an immediate indication of the apparent diachrony for each datum; the total (observed) diachrony is the amount by which the oldest age for the upper limit of the datum exceeds the youngest age estimate for the lower limit of the datum. 
Table 1. Location of sites discussed.

\begin{tabular}{clll}
\hline Site & Longitude & Latitude & $\begin{array}{c}\text { Depth } \\
(\mathrm{m})\end{array}$ \\
\hline ODP 844 & $7^{\circ} 55.279^{\prime} \mathrm{N}$ & $90^{\circ} 28.846^{\prime} \mathrm{W}$ & 3414.5 \\
ODP 845 & $9^{\circ} 34.950^{\prime} \mathrm{N}$ & $94^{\circ} 35.448^{\prime} \mathrm{W}$ & 3704.2 \\
ODP 846 & $3^{\circ} 05.696^{\prime} \mathrm{S}$ & $90^{\circ} 49.078^{\prime} \mathrm{W}$ & 3307.3 \\
ODP 847 & $0^{\circ} 11.593^{\prime} \mathrm{N}$ & $95^{\circ} 19.227^{\prime} \mathrm{W}$ & 3334.3 \\
ODP 848 & $2^{\circ} 59.634^{\prime} \mathrm{S}$ & $110^{\circ} 28.791^{\prime} \mathrm{W}$ & 3853.4 \\
ODP 849 & $0^{\circ} 10.983^{\prime} \mathrm{N}$ & $110^{\circ} 31.183^{\prime} \mathrm{W}$ & 3837.1 \\
ODP 850 & $1^{\circ} 17.837^{\prime} \mathrm{N}$ & $110^{\circ} 31.283^{\prime} \mathrm{W}$ & 3786.1 \\
ODP 851 & $2^{\circ} 46.223^{\prime} \mathrm{N}$ & $110^{\circ} 34.308^{\prime} \mathrm{W}$ & 3761.3 \\
ODP 852 & $5^{\circ} 17.566^{\prime} \mathrm{N}$ & $110^{\circ} 04.579^{\prime} \mathrm{W}$ & 3861.0 \\
ODP 853 & $7^{\circ} 12.661^{\prime} \mathrm{N}$ & $109^{\circ} 45.084^{\prime} \mathrm{W}$ & 3726.0 \\
ODP 854 & $1^{\circ} 13.433^{\prime} \mathrm{N}$ & $109^{\circ} 35.652^{\prime} \mathrm{W}$ & 3567.9 \\
DSDP 608 & $42^{\circ} 50.205^{\prime} \mathrm{N}$ & $23^{\circ} 05.252^{\prime} \mathrm{W}$ & 3526 \\
DSDP 573 & $0^{\circ} 29.91^{\prime} \mathrm{N}$ & $1^{\circ} 33^{\circ} 18.57^{\prime} \mathrm{W}$ & 4301 \\
DSDP 574 & $4^{\circ} 12.52^{\prime} \mathrm{N}$ & $139^{\circ} 19.81^{\prime} \mathrm{W}$ & 4561 \\
ODP 709 & $3^{\circ} 54.9^{\prime} \mathrm{S}$ & $60^{\circ} 33.1^{\prime} \mathrm{W}$ & 3038 \\
ODP 710 & $4^{\circ} 18.7^{\prime} \mathrm{S}$ & $60^{\circ} 58.8^{\prime} \mathrm{E}$ & 3824 \\
ODP 714 & $5^{\circ} 03.6^{\prime} \mathrm{N}$ & $73^{\circ} 47.2^{\prime} \mathrm{E}$ & 2038 \\
& & & \\
\hline
\end{tabular}

The figures in Tables 4 and 5 have been used to make best estimates of the age of each datum.

\section{BEST ESTIMATES FOR BIOSTRATIGRAPHIC DATUMS}

It is not obvious what is the most reliable means for obtaining a "best estimate" for each datum. For the majority of datums, we have made the biostratigrapher's assumption, that the datum is "synchronous" and that the "scatter" is noise. In these cases, our aim was to estimate the age of least conflict, rounded to the nearest $0.01 \mathrm{Ma}$. We worked with two different approaches. For the first approach, we obtained the median of the upper limits, and the median of the lower limits, for each datum. The datum age is the mean of these two figures; obviously, the smaller the difference between the median upper and lower limits, the better the estimate. We chose to use the median, rather than the mean, because the mean is frequently heavily weighted toward the distant values obtained in sites that were sampled at wider depth intervals. For the second approach, we simply took the midpoint between the oldest of all the upper limits, and the youngest of all the lower limits. If the diachrony is large, this method places undue weight on discrepant estimates rather than on the best estimates. We have assumed that if the diachrony is less than the difference between the medians, the second method proves the more reliable estimate. A negative figure for diachrony means that there is no overlap between lower and upper bounds on the estimates for the datum, as one would expect if the datum is synchronous and there are no inconsistencies in the age models or the observations. Moore (this volume) used a graphic method that is related to our second approach, but which is even more conservative. Table 6 gives the estimates of the ages of every datum based on each of our two methods.

In the majority of cases, we assumed that the best estimate for the age of a datum was given by whichever of the two methods outlined above provided the better-constrained estimate. Only in the relatively few cases where diachrony is very clear, have we taken a different approach and looked for the youngest, well-constrained sample for an extinction, and the oldest, well-constrained sample for a first appearance. For ages younger than about $10 \mathrm{Ma}$, we have assumed that the age models are equally good for all sites, except that because it was not possible to develop high-resolution age models based on GRAPE density for Sites 844 and 845 (and parts of Sites 852, 853, and 854), we have used judgment to exclude discrepant estimates from those sites. On the other hand, for the late Miocene, we paid special attention to estimates that have been directly derived from the magnetostratigraphy in the same site. For ages between 13.25 and $10 \mathrm{Ma}$, we have assumed that estimates made in Site 845 , which has a wellpreserved magnetostratigraphy, are more reliable than those based on other sites. This is appropriate since it has not so far proved possible to develop detailed GRAPE density correlations between sites for the interval older than $10 \mathrm{Ma}$. We have no age control other than biostratigraphy for those segments of the age models older than $13.25 \mathrm{Ma}$ for any site. However, it is still useful to examine the degree of consistency among the age estimates.

Moore et al. (1993) took a different approach; they examined the spatial distribution of radiolarian datum ages among the Leg 138 sites. We have not taken this approach for the other microfossil groups for two reasons. First, spatially variable preservation has a more adverse effect on the other groups. Second, although Moore (this volume) attempted to cover all sites at comparable resolution, not all sites were examined at the same resolution for the other fossil groups.

In Table 7, we show four ages for each datum. First, we give the best estimate as estimated above, based on the time scale of Shackleton et al. (this volume) and, hence, related to the magnetic polarity time scale in that chapter (SCHPS94). Second, we recalibrated these estimates to the polarity time scale (CK92) of Cande and Kent (1992). We have not discussed these estimates, but present them for the benefit of those who may choose to work with that scale. Third, we recalibrated the age estimates back to the polarity scale (BKF85) presented by Berggren et al. (1985a). This scale was used for the Neogene time scale of Berggren et al. (1985b), which formed the basis for shipboard work during this and many other ODP cruises. Thus, the figures in this column (labeled "BKF85") may be compared with other estimates that were also based on the BKF85 polarity time scale. Fourth, we give the ages (where available) for those datums, as listed by the Shipboard Scientific Party (1992, tables 4-7). Because most of these ages are derived from BKVC85, they are also based on the BKF85 polarity scale.

In Figure 1, we show the differences between our new estimates for the datum ages and those used by the Shipboard Scientific Party (1992, tables 4-7). Although Figure 1 correctly shows the differences between our new calibrations and those previously in use, it is misleading because it combines the effect of using a new magnetostratigraphic time scale with the effect of improving calibrations with respect to the magnetostratigraphy. For example, the trend of deviations away from the zero line arises from the difference between our magnetostratigraphic time scale and the one that was the basis for the ages used by the Shipboard Scientific Party (1992). Because the objective of this chapter is to examine the biostratigraphic calibrations, we have removed this trend in Figure 2.

In Figure 2, we show differences between our new estimates for the datum ages after recalculation with respect to the BKF85 magnetostratigraphic time scale and the ages used by the Shipboard Scientific Party (1992). Several comments may be made about this figure, which shows the extent to which our calibrations with respect to the magnetic polarity scale differ from those of the Shipboard Scientific Party (1992). First, most of the youngest datums have been studied widely and their ages are already well established with reference to the oxygen isotope record (e.g., Hays and Shackleton, 1976; Thierstein et al., 1976; Morley and Shackleton, 1979; Backman and Shackleton, 1983). As might be expected, in Figure 2, deviations for these datums fall close to the zero line. The diatom datums had not previously been examined in the same way, and we have almost certainly improved their age estimates. Second, in view of the fact that the magnetostratigraphy of Leg 138 extended only to $13.25 \mathrm{Ma}$, ages older than that are dependent on earlier biostratigraphic correlations. Third, the data in Figure 2 are not random; there is a clear tendency for nearby estimates to diverge in the same direction, especially if they are for the same microfossil group. This suggests that there were indeed systematic errors in earlier age estimates and that these were aggravated by the fact that it is only rarely possible to examine all microfossil groups satisfactorily in the same sections.

\section{NANNOFOSSIL CALIBRATIONS}

In the interval from 9 to $13 \mathrm{Ma}$, there are surprising discrepancies between our estimates and those used earlier that deserve comment. 
Table 2. Magnetic polarity time scale used in this work (SCHPS94) and in previous studies (BKF85, CK92).

\begin{tabular}{|c|c|c|c|c|c|c|c|c|c|}
\hline $\begin{array}{c}\text { Name } \\
\text { (BKF85 or } \\
\text { conventional } \\
\text { anomaly) }\end{array}$ & $\begin{array}{c}\text { BKF85 } \\
\text { Age } \\
(\mathrm{Ma})\end{array}$ & $\begin{array}{l}\text { CK92 } \\
\text { Age } \\
(\mathrm{Ma})\end{array}$ & $\begin{array}{l}\text { SCHPS94 } \\
\text { Age } \\
\text { (Ma) }\end{array}$ & $\begin{array}{l}\text { Name } \\
\text { unified } \\
(\mathrm{CK} 92)\end{array}$ & $\begin{array}{c}\text { Name } \\
\text { (BKF85 or } \\
\text { conventional } \\
\text { anomaly) }\end{array}$ & $\begin{array}{c}\text { BKF85 } \\
\text { Age } \\
\text { (Ma) }\end{array}$ & $\begin{array}{l}\text { CK92 } \\
\text { Age } \\
(\mathrm{Ma})\end{array}$ & $\begin{array}{c}\text { SCHPS94 } \\
\text { Age } \\
\text { (Ma) }\end{array}$ & $\begin{array}{l}\text { Name } \\
\text { unified } \\
\text { (CK92) }\end{array}$ \\
\hline Brunhes/Matuyama & 0.73 & 0.780 & 0.780 & $\mathrm{Cln}(\mathrm{o})$ & $5 \mathrm{AA}$ & 12.83 & 12.941 & 12.929 & C5AAn (t) \\
\hline Jaramillo $(\mathrm{t})$ & 0.91 & 0.984 & 0.990 & CIr.In (t) & $5 \mathrm{AA}$ & 13.01 & 13.094 & 13.083 & C5AAn (o) \\
\hline Jaramillo (o) & 0.98 & 1.049 & 1.070 & CIr.In (o) & $5 \mathrm{AB}$ & 13.20 & 13.263 & 13.252 & C5ABn (t) \\
\hline Olduvai $(t)$ & 1.66 & 1.757 & 1.770 & $C_{2} n(t)$ & $5 \mathrm{AB}$ & 13.46 & 13.476 & 13.466 & C5ABn (o) \\
\hline Olduvai (o) & 1.88 & 1.983 & 1.950 & $\mathrm{C} 2 \mathrm{~N}(\mathrm{o})$ & $5 \mathrm{AC}$ & 13.69 & 13.674 & 13.666 & $\mathrm{C5ACn}(\mathrm{t})$ \\
\hline Matuyama/Gauss & 2.47 & 2.600 & 2.600 & $\mathrm{C} 2 \mathrm{An} . \ln (\mathrm{t})$ & $5 \mathrm{AC}$ & 14.08 & 14.059 & 14.053 & C5ACn (o) \\
\hline Kaena (1) & 2.92 & 3.054 & 3.054 & $\mathrm{C} 2 \mathrm{An} \cdot \ln (\mathrm{o})$ & $5 \mathrm{AD}$ & 14.20 & 14.164 & 14.159 & C5ADn (t) \\
\hline Kaena (o) & 2.99 & 3.127 & 3.127 & $\mathrm{C} 2 \mathrm{An} \cdot 2 \mathrm{n}(\mathrm{t})$ & $5 \mathrm{AD}$ & 14.66 & 14.608 & 14.607 & C5ADn (o) \\
\hline Mammoth (t) & 3.08 & 3.221 & 3.221 & $\mathrm{C} 2 \mathrm{An} \cdot 2 \mathrm{n}(\mathrm{o})$ & $5 \mathrm{~B}$ & 14.87 & 14.800 & 14.800 & C5Bn.In (t) \\
\hline mammoth (o) & 3.18 & 3.325 & 3.325 & $\mathrm{C} 2 \mathrm{An} .3 \mathrm{n}(\mathrm{t})$ & $5 B$ & 14.96 & 14.890 & 14.890 & C5Bn. In (o) \\
\hline Gauss/Gilbert & 3.40 & 3.553 & 3.610 & C2An.3n (o) & $5 B$ & 15.13 & 15.038 & 15.038 & C5Bn.2n (t) \\
\hline Cochiti (t) & 3.88 & 4.033 & 4.188 & C $3 n \cdot I n(t)$ & $5 \mathrm{~B}$ & 15.27 & 15.162 & 15.162 & $\operatorname{CsBn} .2 n$ \\
\hline Cochiti (o) & 3.97 & 4.134 & 4.320 & C $3 n . \ln (0)$ & $5 C$ & 16.22 & 16.035 & 16.035 & C5Cn.In (t) \\
\hline Nunivak (t) & 4.10 & 4.265 & 4.478 & $\mathrm{C} 3 \mathrm{n} .2 \mathrm{n}(\mathrm{t})$ & $5 C$ & 16.52 & 16.318 & 16.318 & C5Cn.In (o) \\
\hline Nunivak (o) & 4.24 & 4.432 & 4.604 & $\mathrm{C} 3 \mathrm{n} \cdot 2 \mathrm{n}(\mathrm{o})$ & $5 \mathrm{C}$ & 16.56 & 16.352 & 16.352 & C5Cn.2n (t) \\
\hline Sidufjall (t) & 4.40 & 4.611 & 4.782 & $\mathrm{C} 3 \mathrm{n} \cdot 3 \mathrm{n}(\mathrm{t})$ & $5 \mathrm{C}$ & 16.73 & 16.515 & 16.515 & C5Cn.2n(o) \\
\hline Sidujfall (o) & 4.47 & 4.694 & 4.880 & C $3 n .3 n(0)$ & 5C & 16.80 & 16.583 & 16.583 & $\mathrm{C} 5 \mathrm{Cn} .3 \mathrm{n}(\mathrm{t})$ \\
\hline Thvera (t) & 4.57 & 4.812 & 4.981 & $\mathrm{C} 3 \mathrm{n} \cdot 4 \mathrm{n}(\mathrm{t})$ & SC & 16.98 & 16.755 & 16.755 & C5Cn.3n (o) \\
\hline Thvera (o) & 4.77 & 5.046 & 5.228 & C3n.4n (o) & 5D & 17.57 & 17.310 & 17.310 & C5Dn (t) \\
\hline $3 \mathrm{~A}$ & 5.35 & 5.705 & 5.875 & C3An. In (t) & 5D & 17.90 & 17.650 & 17.650 & C5Dn (o) \\
\hline $3 \mathrm{~A}$ & 5.53 & 5.946 & 6.122 & C $3 \mathrm{An} . \ln (\mathrm{o})$ & $5 E$ & 18.56 & 18.317 & 18.317 & CSEn (t) \\
\hline $3 \mathrm{~A}$ & 5.68 & 6.078 & 6.256 & C 3 An. $2 n(t)$ & $5 \mathrm{E}$ & 19.09 & 18.817 & 18.817 & C5En (o) \\
\hline \multirow[t]{3}{*}{$3 \mathrm{~A}$} & 5.89 & 6.376 & 6.555 & C 3 An. $2 n(o)$ & 6 & 19.35 & 19.083 & 19.083 & C6n (t) \\
\hline & 6.37 & 6.744 & 6.919 & $\mathrm{C} 3 \mathrm{Bn}(\mathrm{t})$ & 6 & 20.45 & 20,162 & 20.162 & C6n (o) \\
\hline & 6.50 & 6.901 & 7.072 & $\mathrm{C} 3 \mathrm{Bn}(\mathrm{o})$ & $6 \mathrm{~A}$ & 20.88 & 20.546 & 20.546 & C6An.In (t) \\
\hline 4 & 6.70 & 7.245 & 7.406 & $C 4 n . \ln (t)$ & $6 \mathrm{~A}$ & 21.16 & 20.752 & 20.752 & C6An.In (o) \\
\hline 4 & 6.78 & 7.376 & 7.533 & C4n.In (o) & $6 \mathrm{~A}$ & 21.38 & 21.021 & 21.021 & C6An.2n (t) \\
\hline 4 & 6.85 & 7.464 & 7.618 & $C 4 n .2 n(t)$ & $6 \mathrm{~A}$ & 21.71 & 21.343 & 21.343 & C6An.2n (o) \\
\hline 4 & 7.28 & 7.892 & 8.027 & C4n.2n (o) & 6AA & 21.90 & NA & & \\
\hline 4 & 7.35 & 8.047 & 8.174 & $\mathrm{C} 4 \mathrm{r} \cdot \ln (\mathrm{t})$ & $6 \mathrm{AA}$ & 22.06 & NA & & \\
\hline 4 & 7.41 & 8.079 & 8.205 & C4r. In (o) & $6 \mathrm{AA}$ & 22.25 & 21.787 & 21.787 & C6AAn (t) \\
\hline $4 \mathrm{~A}$ & 7.90 & 8.529 & 8.631 & C4An (t) & $6 \mathrm{AA}$ & 22.35 & 21.877 & 21.877 & C6AAn (o) \\
\hline $4 \mathrm{~A}$ & 8.21 & 8.861 & 8.945 & C4An (o) & $6 \mathrm{~B}$ & 22.57 & 22.166 & 22.166 & C6AAr.In (t) \\
\hline $4 \mathrm{~A}$ & 8.41 & 9.069 & 9.142 & $\mathrm{C} 4 \mathrm{Ar}, \operatorname{In}(\mathrm{t})$ & & NA & 22.263 & 22.263 & C6AAr. In (o) \\
\hline \multirow[t]{3}{*}{$4 \mathrm{~A}$} & 8.50 & 9.149 & 9.218 & C4Ar. In (o) & & NA & 22.471 & 22.471 & C6AAr.2n (t) \\
\hline & 8.71 & 9.428 & 9.482 & $\mathrm{C} 4 \mathrm{Ar} .2 \mathrm{n}(\mathrm{t})$ & $6 \mathrm{~B}$ & 22.97 & 22.505 & 22.505 & C6AAr.2n (o) \\
\hline & 8.80 & 9.491 & 9.543 & C4Ar.2n (o) & $6 C$ & 23.27 & 22.599 & 22.599 & C6Bn. In (t) \\
\hline 5 & 8.92 & 9.592 & 9.639 & CSn. In (t) & $6 \mathrm{C}$ & 23.44 & 22.760 & 22.760 & C6Bn.In (o) \\
\hline \multirow[t]{5}{*}{5} & 10.42 & 10.834 & 10.839 & C5n.2n (o) & $6 \mathrm{C}$ & 23.55 & 23.357 & 23.357 & C6Cn.In (t) \\
\hline & 10.54 & 10.940 & 10.943 & $C 5 r \cdot \ln (t)$ & $6 \mathrm{C}$ & 23.79 & 23.537 & 23.537 & C6Cn.In (o) \\
\hline & 10.59 & 10.989 & 10.991 & C5r. $\ln (\mathrm{o})$ & $6 C$ & 24.04 & 23.678 & 23.678 & C $6 \mathrm{Cn} .2 \mathrm{n}(\mathrm{t})$ \\
\hline & 11.03 & 11.378 & 11.373 & C5r.2n (t) & $6 \mathrm{C}$ & 24.21 & 23.800 & 23.800 & C6Cn.2n (o) \\
\hline & 11.09 & 11.434 & 11.428 & C $5 r .2 n(o)$ & & NA & 23.997 & 23.997 & $\mathrm{C} 6 \mathrm{Cn} .3 \mathrm{n}(\mathrm{t})$ \\
\hline $5 \mathrm{~A}$ & 11.55 & 11.852 & 11.841 & C5An.In (t) & & NA & 24.115 & 24.115 & C6Cn.3n (o) \\
\hline $5 \mathrm{~A}$ & 11.73 & 12.000 & 11.988 & C5An. In (o) & 7 & 25.5 & 24.722 & 24.722 & $C 7 n \cdot \ln (t)$ \\
\hline $5 \mathrm{~A}$ & 11.86 & 12.108 & 12.096 & C5An.2n (t) & & & & & \\
\hline
\end{tabular}

C5An. $2 n(0)$
C5Ar.In (t) Notes: BKF85 = Berggren et al. (1985a), CK92 = Cande and Kent (1992), and

$\begin{array}{llll}12.46 & 12.618 & 12.605 & \operatorname{C} 5 \operatorname{Ar} . \operatorname{In}(\mathrm{t}) \\ 12.49 & 12.649 & 12.637 & \operatorname{C} 5 \mathrm{Ar} . \ln (\mathrm{o})\end{array}$

$\begin{array}{llll}12.58 & 12.718 & 12.705 & \text { C5Ar.2n }(t)\end{array}$ SCHPS94 = Shackleton et al. (this volume), $(\mathrm{t})=$ termination and $(\mathrm{o})=$ onset.
In BKF85 column, NA $=$ not present in Berggren et al. $(1985 \mathrm{a})$. In CK92 column, NA = exact equivalent not present in Cande and Kent (1992).

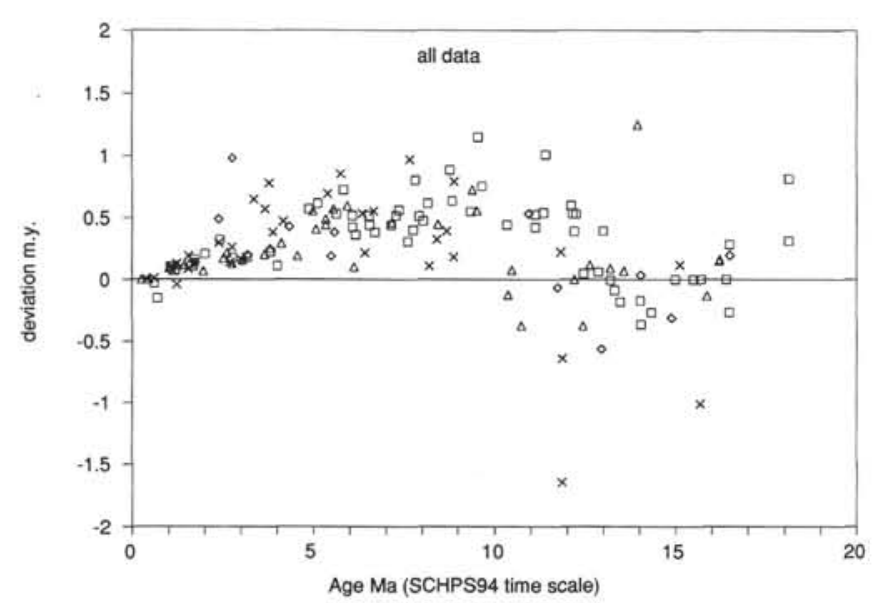

Figure 1. Differences between literature ages (Shipboard Scientific Party, 1992, largely based on, or intended to be consistent with, Berggren et al., 1985b) and ages estimated on the basis of Leg 138 results, based on the SCHPS94 time scale (Shackleton et al., this volume). Open squares $=$ diatoms, open diamonds = foraminifers, open triangles $=$ nannofossils, and crosses $=$ radiolarians.

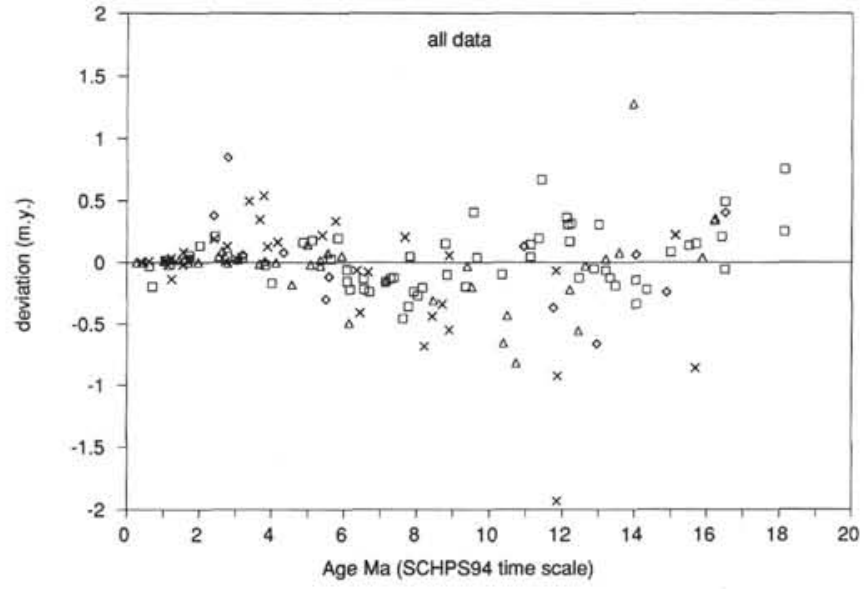

Figure 2. Differences between literature ages (Shipboard Scientific Party, 1992, largely based on, or intended to be consistent with, Berggren et al., $1985 \mathrm{~b}$ ) and ages estimated on the basis of Leg 138 results, but recalculated in terms of the magnetic polarity time scale used by Berggren et al. (1985a). Symbols as in Figure 1. 
Table 3. Depths (mcd) of datums in Leg 138 sites.

\begin{tabular}{|c|c|c|c|c|c|c|c|c|c|c|c|}
\hline & & $\begin{array}{l}844 \\
\text { (t) }\end{array}$ & $\begin{array}{l}844 \\
\text { (o) }\end{array}$ & $\begin{array}{l}845 \\
\text { (t) }\end{array}$ & $\begin{array}{l}845 \\
\text { (o) }\end{array}$ & $\begin{array}{c}846 \\
\text { (t) }\end{array}$ & $\begin{array}{l}846 \\
\text { (o) }\end{array}$ & $\begin{array}{c}847 \\
(t)\end{array}$ & $\begin{array}{l}847 \\
\text { (o) }\end{array}$ & $\begin{array}{c}848 \\
(t)\end{array}$ & $\begin{array}{l}848 \\
\text { (o) }\end{array}$ \\
\hline$t$ & N. reinholdii & NA & NA & 23.15 & 25.02 & 21.37 & 23.75 & 12.37 & 14.83 & 8.44 & 12.27 \\
\hline$t$ & N. fossilis & 1.20 & 2.40 & 21.25 & 24.25 & 23.75 & 26.22 & 16.21 & 20.05 & 8.44 & 12.27 \\
\hline $\mathrm{t}$ & R. matuyama & NA & NA & 24.25 & 25.75 & 34.63 & 39.21 & NA & $\mathrm{NA}$ & NA & NA \\
\hline b & R. matuyama & NA & NA & 25.75 & 27.25 & 49.95 & 50.74 & NA & NA & $\mathrm{NA}$ & $\mathrm{NA}$ \\
\hline t & R. praebergonii var. robusta & NA & NA & $\mathrm{NA}$ & NA & 67.00 & 67.50 & 52.20 & 54.56 & 24.35 & 25.68 \\
\hline b & P. dolius & 17.00 & 19.92 & 38.62 & 39.91 & 73.30 & 74.00 & 67.35 & 68.85 & 28.06 & 28.25 \\
\hline $\mathrm{t}$ & T. convexa & 24.30 & 28.60 & 46.81 & 48.31 & 80.50 & 80.80 & 79.78 & 81.01 & 29.75 & 30.51 \\
\hline $\mathrm{t}$ & N. jouseae & 17.55 & 24.93 & 50.66 & 51.30 & 107.10 & 108.70 & 92.58 & 94.83 & 31.35 & 32.75 \\
\hline b & R. praebergonii & 19.92 & 24.93 & 51.30 & 53.16 & 125.50 & 125.70 & 102.91 & 104.10 & 34.35 & 34.64 \\
\hline b & T. convexa f. convexa & $\mathrm{NA}$ & NA & 61.16 & 62.66 & 148.70 & 149.60 & 121.23 & 124.61 & 37.55 & 39.05 \\
\hline$b$ & A. elegans & NA & NA & $\mathrm{NA}$ & NA & $\mathrm{NA}$ & NA & 127.10 & 135.05 & 35.52 & 43.55 \\
\hline$t$ & N. cylindrica & NA & NA & 72.67 & 74.17 & 191.02 & 193.76 & 145.83 & 153.76 & 43.55 & 46.18 \\
\hline b & N. jouseae & 24.93 & 37.85 & 71.17 & 72.67 & 202.45 & 203.50 & 177.25 & 180.25 & 48.60 & 50.75 \\
\hline I & T. miocenica & 36.00 & 37.85 & 86.31 & 87.61 & 233.45 & 234.25 & 184.54 & 193.87 & NA & NA \\
\hline b & T. oestrupii & NA & NA & 79.60 & 80.65 & 233.45 & 234.25 & NA & NA & $\mathrm{NA}$ & NA \\
\hline$t$ & N. miocenica & NA & NA & 89.31 & 90.61 & 249.90 & 250.26 & 193.87 & 204.90 & 59.10 & 63.06 \\
\hline$t$ & N. miocenica var, elongata & 33.00 & 36.00 & $\mathrm{NA}$ & NA & 250.26 & 261.18 & NA & NA & 63.60 & 65.07 \\
\hline $\mathrm{t}$ & T. praeconvexa & 24.93 & 37.85 & NA & NA & 250.26 & 261.18 & 215.60 & 222.75 & 63.60 & 69.35 \\
\hline$t$ & R. praepaleacea & NA & NA & NA & NA & NA & $\mathrm{NA}$ & NA & NA & 69.35 & 70.85 \\
\hline b & T. miocenica & NA & NA & 92.08 & 102.09 & 266.01 & 267.22 & NA & NA & 70.85 & 71.85 \\
\hline b & T. convexa var. aspinosa & 37.85 & 39.35 & 92.08 & 102.09 & 266.01 & 267.22 & NA & NA & 70.85 & 71.85 \\
\hline b & T. praeconvexa & 39.35 & 41.55 & NA & NA & 267.22 & 271.90 & $\mathrm{NA}$ & NA & 72.35 & 73.85 \\
\hline $\mathrm{t}$ & N. porteri & NA & NA & $\mathrm{NA}$ & NA & 283.00 & 284.05 & NA & NA & $\mathrm{NA}$ & NA \\
\hline b & N. miocenica & 42.33 & 43.85 & 92.37 & 107.06 & 288.30 & 288.70 & NA & NA & 80.16 & 80.75 \\
\hline$t$ & R. paleacea & 42.33 & 43.85 & NA & NA & 293.60 & 293.80 & NA & NA & 80.16 & 80.75 \\
\hline $\mathrm{t}$ & T. burckliana & NA & NA & $\mathrm{NA}$ & NA & $\mathrm{NA}$ & NA & NA & NA & $\mathrm{NA}$ & $\mathrm{NA}$ \\
\hline b & N. reinholdii & 43.85 & 45.35 & $\mathrm{NA}$ & NA & NA & NA & NA & NA & NA & NA \\
\hline $\mathrm{t}$ & A. ellipticus var. javanicus & $\mathrm{NA}$ & NA & $\mathrm{NA}$ & NA & NA & NA & NA & NA & NA & NA \\
\hline b & N. marina & NA & NA & $\mathrm{NA}$ & NA & NA & NA & NA & NA & NA & NA \\
\hline b & N. cylindrica & 47.80 & 49.30 & $\mathrm{NA}$ & NA & 309.60 & 310.20 & NA & NA & NA & NA \\
\hline$t$ & T. yabei & 46.55 & 47.80 & 121.79 & 123.69 & 310.00 & 310.20 & NA & NA & $\mathrm{NA}$ & NA \\
\hline$b$ & A. nodulifer var. cyclops & NA & $\mathrm{NA}$ & $\mathrm{NA}$ & NA & NA & $\mathrm{NA}$ & $\mathrm{NA}$ & NA & NA & NA \\
\hline $\mathrm{t}$ & C. loeblichii & 53.80 & 56.62 & $\mathrm{NA}$ & NA & $\mathrm{NA}$ & $\mathrm{NA}$ & NA & NA & $\mathrm{NA}$ & NA \\
\hline b & N. fossilis & NA & NA & NA & NA & NA & NA & NA & NA & NA & NA \\
\hline b & $T$. burckliana & 53.80 & 56.62 & $\mathrm{NA}$ & NA & NA & NA & $\mathrm{NA}$ & NA & $\mathrm{NA}$ & $\mathrm{NA}$ \\
\hline b & C. loeblichii & 56.62 & 68.76 & $\mathrm{NA}$ & NA & NA & NA & NA & NA & NA & $\mathrm{NA}$ \\
\hline $\mathrm{t}$ & D. hustedtii & 65.70 & 68.76 & 134.74 & 145.65 & 328.44 & 328.60 & NA & NA & $\mathrm{NA}$ & NA \\
\hline$t$ & A. moronensis & 69.86 & 71.35 & NA & NA & NA & NA & NA & NA & NA & NA \\
\hline b & A. ellipticus f. lanceolata & NA & NA & $\mathrm{NA}$ & NA & 337.48 & 347.78 & NA & NA & NA & NA \\
\hline b & R. paleacea var. elongata & NA & NA & NA & NA & 355.00 & 356.20 & NA & NA & NA & NA \\
\hline $\mathrm{t}$ & C. gigas v. diorama & NA & NA & 166.35 & 170.64 & 355.00 & 356.20 & NA & $\mathrm{NA}$ & $\mathrm{NA}$ & NA \\
\hline$t$ & S. jouseana & 89,75 & 100.90 & NA & NA & $\mathrm{NA}$ & NA & NA & NA & NA & NA \\
\hline $\mathrm{t}$ & C. coscinodiscus & 89.75 & 100.90 & NA & NA & 355.00 & 356.20 & NA & NA & NA & NA \\
\hline $\mathrm{t}$ & A. ingens & 123,12 & 132.75 & 188.97 & 190.96 & 371.70 & 373.83 & NA & NA & NA & NA \\
\hline $\mathrm{t}$ & C. pulchellus & 123.12 & 132.25 & 176.76 & 188.97 & NA & $\mathrm{NA}$ & NA & NA & NA & NA \\
\hline $\mathrm{t}$ & N. porteri & NA & NA & $\mathrm{NA}$ & NA & 373.83 & 376.63 & NA & NA & NA & NA \\
\hline b & T. brunii & 123.12 & 132.95 & NA & NA & 373.83 & 374.00 & NA & NA & $\mathrm{NA}$ & NA \\
\hline b & C. gigas v. diorama & NA & NA & NA & NA & 388.50 & 389.40 & NA & NA & NA & NA \\
\hline $\mathrm{t}$ & A. californicus & 126.15 & 132.75 & NA & NA & NA & NA & NA & NA & NA & NA \\
\hline $\mathrm{t}$ & C. lewisianus & 147.71 & 152.82 & 205.15 & 211.06 & 387.00 & 390.30 & NA & NA & NA & NA \\
\hline $\mathrm{t}$ & T. tappanae & 152.82 & 163.61 & $\mathrm{NA}$ & NA & $\mathrm{NA}$ & $\mathrm{NA}$ & NA & NA & NA & NA \\
\hline b & T. cinnamoneum & 157.70 & 167.61 & $\mathrm{NA}$ & NA & $\mathrm{NA}$ & NA & NA & NA & NA & $\mathrm{NA}$ \\
\hline b & D. simonsenii & 163.61 & 172.67 & NA & NA & $\mathrm{NA}$ & $\mathrm{NA}$ & NA & NA & NA & NA \\
\hline & C. peplum & 172.67 & 183.48 & 251.00 & 270.75 & NA & NA & NA & NA & NA & NA \\
\hline & A. ellipticus & 183.48 & 193.03 & NA & NA & $\mathrm{NA}$ & $\mathrm{NA}$ & NA & NA & $\mathrm{NA}$ & NA \\
\hline
\end{tabular}

Notes: Full generic names appear in Table 6. In column headings, $(t)=$ termination, and $(o)=$ onset. In first column, $t=$ top of range, $b=$ bottom of range, $t c=$ top of common occurrence, and $\mathrm{bc}=$ bottom of common occurrence. $\mathrm{NA}=$ not present.

Only the first page of this table is reproduced here. The entire table appears on the CD-ROM (back pocket).

First, our age for the base of Discoaster hamatus, when converted back to BKF85, is $9.87 \mathrm{Ma}$, whereas Backman et al. (1990) derived an age of $10.50 \mathrm{Ma}$ at tropical Indian Ocean DSDP Site 710 with primary magnetostratigraphic control. However, Olafsson (1991) obtained an age of $9.9 \mathrm{Ma}$ in Site 608 in the North Atlantic, also with primary magnetostratigraphy. The base of C $5 \mathrm{~N} .2 \mathrm{n}$ is more securely determined both in that site and in Site 845 than in Site 710 . We conclude that our estimate is probably better than that of Backman et al. (1990).

The upper limit of Coccolithus miopelagicus in Site 608 is some distance below the base of Discoaster hamatus (Olafsson, 1991), whereas the two datums are consistently close to each other in Leg 138 sites (but in both regions, the upper limit of $C$. miopelagicus lies between the first occurrences of Catinaster coalitus and D. hamatus). Our estimate for the age of the base of $D$. hamatus is consistent with that of Olafsson (1991). Thus, it seems likely that C. miopelagicus disappeared earlier in the region of Site 608 than in the equatorial Pacific and, hence, that ours is the more reliable estimate of the true last appearance datum (LAD) of the species.

The base of Catinaster coalitus was estimated at $11.1 \mathrm{Ma}$ by Backman et al. (1990), whereas our estimate is equivalent to 10.31 $\mathrm{Ma}$ on the BKF85 scale. However, Backman et al. (1990) based their estimate on an interpolation between the base of Discoaster hamatus (for which they used an age of $10.5 \mathrm{Ma}$ ) and the upper limit of Sphenolithus heteromorphus at $13.5 \mathrm{Ma}$; their estimate would be closer to ours using our age (discussed above) for the base of $D$. hamatus, and we conclude that our estimate is reliable.

Our age for the upper limit of Coronocyclus nitescens is equivalent to $11.86 \mathrm{Ma}$ on the BKF85 scale, whereas Rio et al. (1990) obtained $12.66 \pm 0.19 \mathrm{Ma}$ at tropical Indian Ocean DSDP Site 714 Their age is based on an interpolation between the ages for the base of Catinaster coalitus and the upper limit of Sphenolithus hetero- 
morphus, using the ages obtained by Backman et al. (1990). Using our ages for these two events, the discrepancy is significantly reduced. The uncertainty quoted by Rio et al. (1990) is based on the large gap between the conventional depth (mbsf) for the core-catcher sample and the remainder of the recovered core; probably a younger age estimate would be more realistic, also, in view of the fact that the base of Discoaster kugleri was observed higher in the same core (recovery in Site 714, Core $9 \mathrm{H}$ was less than $5 \mathrm{~m}$; we assume that the sample given in Rio et al., 1990, table 26, as 714A-9H-5-30 was, in fact, 714A-9H-4-30).

The age for the base of Discoaster kugleri in Site 714 (Backman et al., 1990) was again based on a linear interpolation between the base of $D$. hamatus (for which they used an age of $10.5 \mathrm{Ma}$ ) and the upper limit of $S$. heteromorphus at $13.5 \mathrm{Ma}$; our estimate is not in conflict with their data. The sedimentation rate in Site 714 was low and, in light of our findings, it is significant that Rio et al. (1990) found the upper limit for Coronocyclus nitescens at the same position as the lower limit of D. kugleri in Site 709, which has a much higher sedimentation rate, confirming that these datums are close in age.

For the base of Triquetrorhabdalus rugosus, our estimate is essentially identical, when converted to the BKF85 scale, with that obtained by Olafsson in Site 608 with direct paleomagnetic control. Our estimate for the upper limit of Cyclicargolithus floridanus agrees well with that given by Backman et al. (1990), based on an interpolation at central Pacific DSDP Site 574. Olafsson (1991) showed that this species survived much longer at mid-latitude Site 608 (see also Raffi et al., this volume). However, our estimate for the base of Reticulofenestra pseudoumbilicus is equivalent to $13.88 \mathrm{Ma}$ on the BKF85 scale, much older than the 12.70 Ma estimate of Olafsson based on Site 608. In Site 608, the base of $R$. pseudoumbilicus is well separated from the upper limit of Sphenolithus heteromorphus, whereas at the three Leg 138 sites that contain both datums, they were observed to coincide. Because our estimate for the top of $S$. heteromorphus is only slightly older than Olafsson's estimate based on Site 608, we assume that this datum is essentially synchronous and that the first appearance of $R$. pseudoumbilicus in the region of Site 608 is nearly $1 \mathrm{~m}$.y. after its first appearance in the Leg 138 region. Our estimate in Table 4 for the upper limit of $S$. heteromorphus depends on a somewhat poorly constrained age model in Site 845, and an extension of the sedimentation rate observed in the interval with magnetostratigraphic control yields a younger age estimate (about 13.47 Ma; Raffi and Flores, this volume) that is closer to that estimated by Olafsson (1991).

\section{RADIOLARIAN AND DIATOM CALIBRATIONS}

The ages for several of the radiolarian datums have been compared with estimates (Shipboard Scientific Party, 1992) that were made by Johnson and Nigrini (1985) for the central Pacific DSDP Site 573. Their estimates were based on an age model for the site that, in turn, depended on datum levels for the other microfossil groups, so that precise comparison is inappropriate; we comment only on those cases where a major disagreement is evident. Our age for the base of Diartus pettersoni is equivalent to $11.56 \mathrm{Ma}$ on the BKF85 scale, about $1 \mathrm{~m}$.y. younger than that given by Johnson and Nigrini (1985) for Site 573. However, these authors observed much younger first appearances in the western Pacific (11.0-11.3 Ma) and the Indian Ocean (10.6-10.8 Ma), so that the first appearance of this species may be significantly diachronous (conceivably explaining the seemingly earlier appearance in Site 846). The upper limit of Dorcadospyris alata displays an even greater discrepancy; again, however, Johnson and Nigrini (1985) reported widely discrepant estimates in different regions, with our estimate being closer to theirs for the western Pacific and for Site 573.

Regarding the diatom datums, it is significant that a number of the literature estimates that we use (Shipboard Scientific Party, 1992) are based on pioneering work by Burckle (1978) on piston cores from the equatorial Pacific Ocean that preserved magnetostratigraphic rec- ords, but at a major sacrifice in sedimentation rate. In general, our age estimates are close to the published figures, but with a pattern of consistent offsets for nearby datums that probably arise from artifacts of very low accumulation rate. We assume that our estimates, based on higher sedimentation rates, are more reliable.

Our age estimates for the last appearance of Nitzschia cylindrica and the first appearance of Nitzschia jousseae are older than those of Burckle (1978) and Barron et al. (1985a). It is possible that this reflects a difference in species concepts, because forms intermediate between the two species were observed in Leg 138 sediments. Similarly, the age of the first appearance of Thalassiosira oestrupii may be affected by differing species concepts.

\section{FORAMINIFERAL DATUMS}

For the upper limit of Globigerinoides fistulosus, we have included additional data from Sites 846 and 849 contributed by A.C. Mix (pers. comm., 1993). Samples typically contain only one or two specimens, but one may assume that these are not reworked, as there is no reservoir of material rich in this species to provide reworked specimens. The upper limit in Site 846 is at about the same age as observed in Site 677 (Shackleton et al., 1990), but in Site 849 it is somewhat earlier. Several of the Pliocene datums were only determined at close intervals in Site 846 (Shackleton et al., this volume); the estimates provided by that site are in excellent agreement with previous data. In the middle Miocene sections, useful calibrations come from Sites 844, 845, and 846.

\section{INDIVIDUAL SITE AGE-DEPTH PLOTS}

Figures 3 through 13 show the limits within which each datum is placed in each site, plotted at the ages estimated in Table 7 (column labeled "SCHPS94"). For each site, the line represents the age model from Shackleton et al. (this volume). These figures enable us to identify site-specific problems (sedimentation rates are given by Shackleton et al., this volume). For example, Figure 5 suggests that there is a problem in the lower part of Site 846, where the base of Discoaster kugleri and the base of Diartus pettersoni both fall well off the calibration line. These two datums fall in Core 138-846B-38X; the recovery in Core 138-846B-37X was low, and nothing was recovered in Core 138-846B-39X. The distribution of $D$. kugleri above its reported first appearance is erratic, and it is possible that this core contains mixed material, although Raffi et al. (this volume) remind us that the first appearance of $D$. kugleri is an unreliable marker.

In Figure 3 (Site 844), the apparent wide limits on the deepest two diatom datums indicate that they fall between the lowest sample examined and the bottom of the hole. In Figure 6 (Site 847), the departures of three diatom datums from the age-depth line may indicate an error in the age model, but this is not certain because in this site the diatom stratigraphy is based only on shipboard work. In Figures 12 and 13 (Sites 853 and 854), a combination of poor preservation and low sedimentation rate limited the time resolution of many determinations.

\section{WHICH DATUMS ARE SYNCHRONOUS?}

Moore et al. (1993) have already examined the radiolarian datum levels discussed here and separated out those that are broadly synchronous over the range covered by Leg 138 from those that are not. They were able to show, for those datums that are clearly nonsynchronous, that the spatial pattern of each extinction or first appearance is related to the presence of the species in some, but not all, of the water masses overlying the Leg 138 coring sites, either shortly after the species first appears, or as its geographic range is reduced before extinction. Clearly, the reverse is axiomatically true: a datum cannot appear synchronous unless the species spread rapidly into all the relevant water masses when it first appeared, and its demise was not preceded by a perceptible contraction in viable range. 
Table 4. Ages (Ma) of datums in Leg 138 sites.

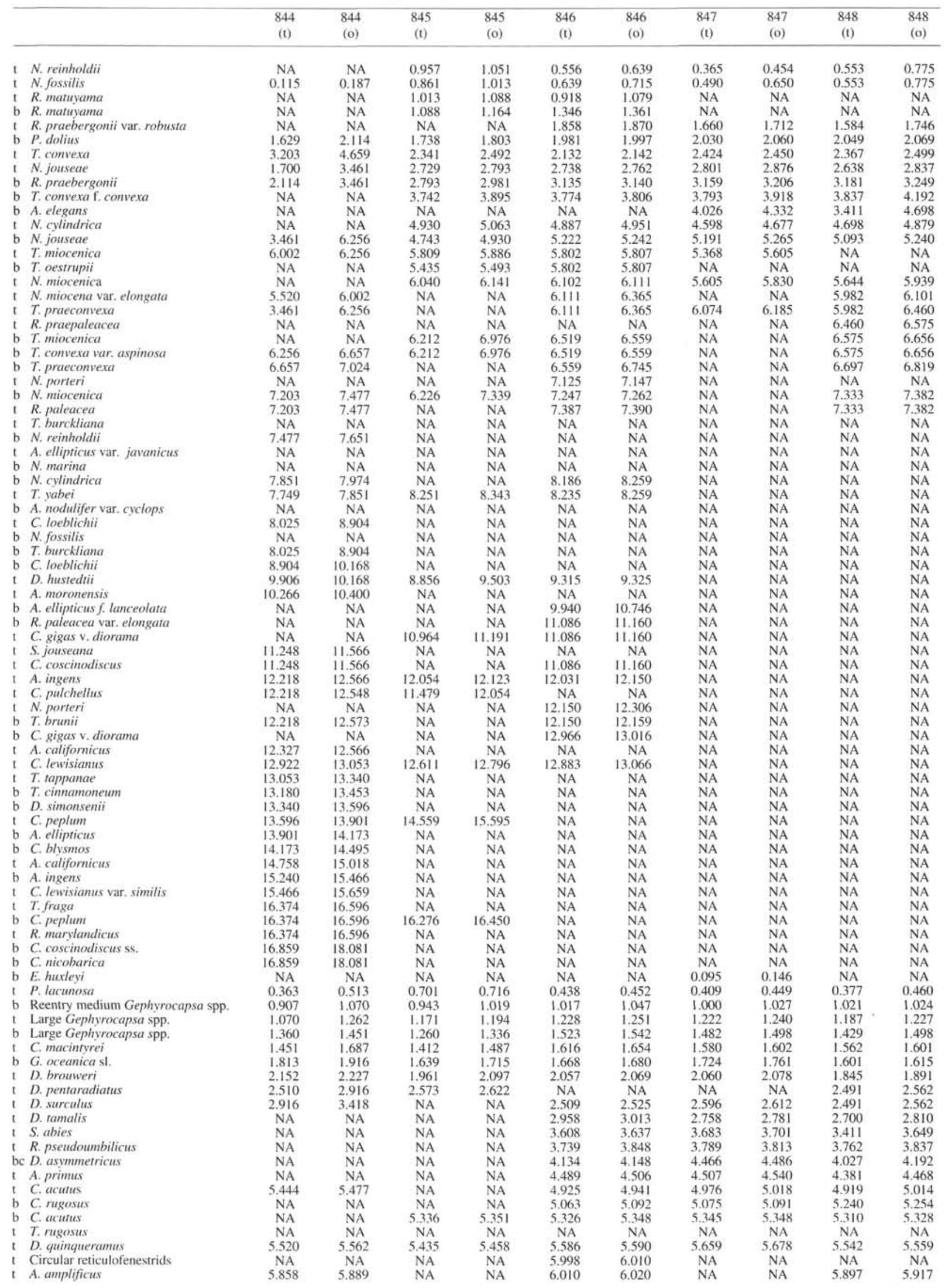


Table 4 (continued).

\begin{tabular}{|c|c|c|c|c|c|c|c|c|c|c|}
\hline & $\begin{array}{c}844 \\
(t)\end{array}$ & $\begin{array}{l}844 \\
\text { (o) }\end{array}$ & $\begin{array}{c}845 \\
\text { (t) }\end{array}$ & $\begin{array}{l}845 \\
\text { (o) }\end{array}$ & $\begin{array}{c}846 \\
(t)\end{array}$ & $\begin{array}{l}846 \\
(0)\end{array}$ & $\begin{array}{c}847 \\
\text { (t) }\end{array}$ & $\begin{array}{l}847 \\
\text { (o) }\end{array}$ & $\begin{array}{c}848 \\
\text { (t) }\end{array}$ & $\begin{array}{l}848 \\
\text { (o) }\end{array}$ \\
\hline b A. amplificus & 6.608 & 6.656 & 6.552 & 6.583 & 6.108 & 6.153 & NA & NA & 6.490 & 6.509 \\
\hline b Circular reticulofenestrids & NA & NA & NA & NA & 6.399 & 6.459 & NA & NA & NA & NA \\
\hline t Absence $R$. pseudoumbilicus & 6.894 & 6.946 & 6.744 & 6.783 & 7.039 & 7.070 & NA & NA & 6.913 & 6.929 \\
\hline b A. primus & 7.208 & 7.354 & 7.175 & 7.381 & 7.111 & 7.122 & NA & NA & 7.316 & 7.364 \\
\hline t M. convallis & 7.693 & 7.733 & NA & NA & 7.716 & 7.789 & NA & NA & 8.245 & 8.362 \\
\hline b $D$, berggrenii & 8.014 & 8.008 & 8.461 & 8.485 & 7.927 & 7.953 & NA & NA & 8.362 & 8.473 \\
\hline b $D$, pentaradiatus & 8.008 & 8.004 & NA & NA & NA & NA & NA & NA & NA & NA \\
\hline b D. loeblichi & 8.004 & 8.306 & $\mathrm{NA}$ & NA & 8.394 & 8.500 & NA & NA & 8.535 & 8.599 \\
\hline b Absence $R$. pseudoumbilicus & 8.695 & 8.758 & NA & NA & 8.631 & 8.713 & NA & NA & 8.535 & 8.599 \\
\hline t D. hamatus & 9.373 & 9.404 & NA & NA & 9.760 & 9.798 & NA & NA & 9.379 & 9.408 \\
\hline b $M$. convallis & 9.358 & 9.397 & NA & NA & 9.337 & 9.434 & NA & NA & 9.182 & 9.206 \\
\hline b D. neohamatus & NA & NA & NA & NA & NA & NA & NA & NA & 9.538 & 9.660 \\
\hline b $C$. coalitus & 10.692 & 10.761 & 10.710 & 10.743 & 10.696 & 10.723 & NA & NA & NA & NA \\
\hline b D. hamatus & 10.213 & 10.347 & 10.272 & 10.290 & 10.403 & 10.492 & NA & NA & 10.261 & 10.288 \\
\hline t C. miopelagicus & 10.347 & 10.481 & 10.417 & 10.431 & 10.551 & 10.640 & NA & NA & 10.288 & 10.317 \\
\hline$t$ C. floridanus & 13.558 & 13.583 & 13.183 & 13.201 & 13.330 & 14.054 & NA & $\mathrm{NA}$ & NA & NA \\
\hline $\mathrm{t}$ C. nitescens & 12,412 & 12.445 & 12.107 & 12.130 & 13.330 & 14.054 & NA & NA & NA & NA \\
\hline tc D. kugleri & 11.311 & 11.360 & 11.364 & 11.384 & 11.335 & 11.369 & NA & NA & NA & NA \\
\hline bc D. kugleri & 11.771 & 11.787 & 11.702 & 11.719 & 11.779 & 11.875 & NA & NA & NA & NA \\
\hline b D. kugleri & 12.391 & 12.412 & 12.130 & 12.145 & 13.278 & 13.317 & NA & NA & NA & NA \\
\hline b C. macintyrei & NA & NA & 12.130 & 12.145 & NA & NA & NA & NA & NA & NA \\
\hline I C. premacintyrei & 12.764 & 12.797 & 12.228 & 12.262 & NA & NA & NA & $\mathrm{NA}$ & NA & NA \\
\hline b T. rugosus & 12.946 & 12.970 & 12.636 & 12.677 & NA & NA & NA & NA & NA & NA \\
\hline t D. signus & 13.042 & 13.107 & NA & NA & NA & NA & NA & NA & NA & NA \\
\hline b R. pseudoumbilicus & 14.039 & 14.055 & 13.840 & 13.861 & 13.330 & 14.054 & NA & NA & NA & NA \\
\hline t S. heteromorphus & 14.039 & 14.055 & 13.840 & 13.861 & 13.330 & 14.054 & NA & NA & NA & NA \\
\hline t H. ampliapertura & 15.786 & 15.840 & 15.898 & 15.912 & 15.644 & 15.939 & NA & NA & NA & NA \\
\hline b D. signus & 16.204 & 16.219 & 16.187 & 16.202 & 15.971 & 16.484 & NA & NA & NA & NA \\
\hline t Acme D. deflandrei & NA & NA & 16.202 & 16.229 & NA & NA & NA & NA & NA & NA \\
\hline $\mathrm{t}$ S. universus & 0.363 & 0.737 & 0.402 & 0.423 & 0.381 & 0.417 & 0.404 & 0.490 & 0.474 & 0.561 \\
\hline b C. tuberosa & 0.363 & 0.737 & 0.575 & 0.701 & 0.454 & 0.603 & 0.583 & 0.662 & 0.632 & 0.644 \\
\hline t $L$ neoheteroporos & 0.942 & 1.083 & 1.024 & 1.053 & 0.988 & 1.053 & 1.067 & 1.094 & 1.089 & 1.120 \\
\hline t A. angulare & 0.942 & 1.083 & 1.053 & 1.099 & 1.116 & 1.145 & 1.094 & 1.148 & 1.122 & 1.154 \\
\hline $\mathrm{t} T$. vetulum & 1,083 & 1.451 & 1.124 & 1.194 & 1.222 & 1.257 & 1.223 & 1.260 & 1.154 & 1.186 \\
\hline b $L$ nigriniae & 1.083 & 1.451 & 1.194 & 1.279 & 1.222 & 1.257 & 1.148 & 1.223 & 1.220 & 1.251 \\
\hline b $T$. trachelium & 1.451 & 1.933 & 1.597 & 1.740 & 1.559 & 1.652 & 1.504 & 1.543 & 1.467 & 1.520 \\
\hline b $P$. minithorax & 1.451 & 1.933 & 1.487 & 1.597 & 1.449 & 1.479 & 1.543 & 1.703 & 1.746 & 1.791 \\
\hline b A. angulare & 1.451 & 1.933 & 1.738 & 1.798 & 1.687 & 1.824 & 1.712 & 1.778 & 1.746 & 1.791 \\
\hline $\mathrm{t}$ P. prismatium & 1.451 & 1.933 & 1.668 & 1.738 & 1.687 & 1.824 & 1.712 & 1.778 & 1.690 & 1.741 \\
\hline t $L$ heteroporos & 1.451 & 1.933 & 1.487 & 1.597 & 2.069 & 2.090 & 2.038 & 2.129 & 1.467 & 1.520 \\
\hline t A. jenghisi & 2.206 & 2.568 & 2.029 & 2.331 & 2.345 & 2.391 & 2.450 & 2.609 & 2.354 & 2.471 \\
\hline b $T$. davisiana & 2.568 & 2.936 & 2.622 & 2.857 & 2.714 & 2.797 & 2.713 & 2.789 & 2.638 & 2.709 \\
\hline $\mathrm{t} S$.peregrina & 2.568 & 2.936 & 2.857 & 2.880 & 2.714 & 2.797 & 2.789 & 2.801 & 2.638 & 2.709 \\
\hline t A. pliocenica & 2.936 & 3.461 & 3.289 & 3.593 & 3.268 & 3.303 & 3.201 & 3.338 & 3.591 & 4.156 \\
\hline b $L$ heteroporos & 2.936 & 3.461 & 3.103 & 3.167 & 3.350 & 3.370 & 2.979 & 3.048 & 2.471 & 2.562 \\
\hline I L. audax & 3.843 & 5.180 & 3.967 & 4.039 & 3.989 & 4.042 & 3.562 & 3.710 & 3.663 & 3.675 \\
\hline t P. fistula & 5.180 & 5.300 & 3.289 & 3.593 & 4.305 & 4.343 & 4.094 & 4.106 & 3.663 & 3.675 \\
\hline b $L$ neoheteroporos & 2.206 & 2.568 & 3.167 & 3.240 & 3.421 & 3.438 & 2.979 & 3.048 & 2.471 & 2.562 \\
\hline t P. dolium & 3.843 & 5.180 & 3.967 & 4.039 & 4.042 & 4.134 & 4.094 & 4.106 & 3.663 & 3.675 \\
\hline b A. ypsilon & 3.461 & 3.843 & 3.593 & 3.641 & 3.650 & 3.748 & 3.918 & 4.094 & 3.804 & 3.926 \\
\hline t D. penultima & 3.843 & 5.180 & 4.737 & 4.849 & 4.134 & 4.183 & 4.106 & 4.227 & 4.052 & 4.149 \\
\hline b $S$, tetras & 3.461 & 5.180 & 3.805 & 3.885 & 4.042 & 4.134 & 4.106 & 4.227 & 4.052 & 4.149 \\
\hline b P. prismatium & 3.461 & 3.843 & 4.329 & 4.358 & 4.719 & 4.734 & 4.829 & 4.865 & 4.751 & 4.786 \\
\hline t $S$. omnitubus & 5.554 & 5.807 & 5.298 & 5.345 & 5.502 & 5.533 & 5.368 & 5.475 & 4.949 & 4.992 \\
\hline t $S$. corona & 5.807 & 6.879 & 7.056 & 7.142 & 5.502 & 5.533 & 5.662 & 5.756 & 5.424 & 5.497 \\
\hline t S. johnsoni & 5.768 & 6.879 & 6.435 & 6.543 & 6.419 & 6.491 & 6.418 & 6.476 & 6.303 & 6.345 \\
\hline b $S$. delmontensis to $S$. peregrina & 5.807 & 6.879 & 6.759 & 6.807 & 6.559 & 6.650 & 6.418 & 6.591 & 6.567 & 6.572 \\
\hline I C. caepa & 5.807 & 6.879 & 6.977 & 7.056 & 6.559 & 6.650 & 6.476 & 6.520 & 6.170 & 6.225 \\
\hline b S. omnitubus & 7.203 & 7.467 & 7.142 & 7.266 & 7.261 & 7.318 & NA & NA & 7.057 & 7.454 \\
\hline t D. hughesi & 7.467 & 7.749 & 7.588 & 7.627 & 7.639 & 7.657 & NA & NA & 7.506 & 7.647 \\
\hline b $S$. berminghami & NA & NA & NA & NA & NA & NA & NA & NA & NA & NA \\
\hline I S. wolffi & 8.000 & 8.904 & 8.796 & 8.854 & 8.841 & 8.872 & $\mathrm{NA}$ & NA & 8.818 & 8.893 \\
\hline t B. miralestensis & 7.749 & 8.022 & 8.214 & 8.247 & 8.366 & 8.590 & NA & NA & 8.017 & 8.198 \\
\hline t D. pettersoni & 8.022 & 8.008 & 8.587 & 8.631 & 8.366 & 8.590 & NA & NA & 8.489 & 8.565 \\
\hline b D. hughesi & 8.000 & 8.904 & 8.854 & 8.903 & 9.181 & 9.315 & NA & NA & 8.818 & 8.893 \\
\hline b $D$. pettersoni to $D$. hughesi & 8.000 & 8.904 & 8.671 & 8.724 & 8.590 & 8.717 & NA & NA & 8.718 & 8.818 \\
\hline $\mathrm{t}$ C. japonica & 9.914 & 10.168 & 10.055 & 10.106 & 10.032 & 10.148 & NA & NA & NA & NA \\
\hline t C. cristata & 10.168 & 10.525 & 10.373 & 10.518 & 10.778 & 10.841 & NA & NA & NA & NA \\
\hline t L. thormburgi & 8.904 & 9.671 & 11.412 & 11.440 & 10.778 & 10.841 & NA & NA & $\mathrm{NA}$ & NA \\
\hline t $L$ renzae & 11.824 & 11.901 & 11,744 & 11,807 & 11.760 & 11.814 & NA & NA & NA & NA \\
\hline t C. comuta & 11.744 & 11.824 & 11.807 & 11.838 & 11.898 & 11.981 & NA & NA & NA & NA \\
\hline b D. pettersoni & 11.824 & 11.901 & 11.807 & 11.838 & 12.974 & 13.225 & $\mathrm{NA}$ & NA & NA & NA \\
\hline I D. alata & 11.824 & 11.901 & 11.838 & 11.869 & NA & NA & $\mathrm{NA}$ & NA & NA & NA \\
\hline b $C$. japonica & 12.327 & 12.351 & 12.428 & 12.501 & 12.348 & 12.437 & NA & NA & NA & NA \\
\hline b C. caepa & 13.510 & 13.593 & 13.121 & 13.194 & NA & NA & NA & NA & NA & NA \\
\hline b L. thornburgi & 12.980 & 13.053 & 13.605 & 13.626 & NA & NA & NA & NA & NA & NA \\
\hline t S. armata & 13.761 & 13.901 & 13.626 & 13.673 & NA & NA & $\mathrm{NA}$ & $\mathrm{NA}$ & $\mathrm{NA}$ & NA \\
\hline I L. parkerae & 14.410 & 14.495 & 14.177 & 14.607 & NA & NA & NA & NA & NA & NA \\
\hline t O. octopyle & 14.495 & 14.597 & 14.177 & 14.607 & NA & NA & $\mathrm{NA}$ & NA & NA & NA \\
\hline t C. bramlettei & 14.882 & 15.018 & 14.177 & 14.607 & NA & NA & NA & NA & $\mathrm{NA}$ & NA \\
\hline t C. costata & 15.173 & 15.249 & 15.010 & 15.052 & NA & NA & NA & $\mathrm{NA}$ & NA & NA \\
\hline b D. dentata to D. alata & 15.466 & 15.566 & 15.846 & 15.861 & NA & NA & NA & NA & NA & NA \\
\hline t L stauropora & 15.659 & 15.774 & 15.903 & 15.919 & NA & NA & NA & NA & NA & NA \\
\hline b $L$ parkerae & 15.659 & 15.774 & 15.919 & 15.932 & NA & NA & NA & NA & $\mathrm{NA}$ & NA \\
\hline t $S$. diaphenes & 15.844 & 15.919 & 16.011 & 16.025 & NA & NA & NA & NA & NA & NA \\
\hline b C. bramlettei & 17.019 & 17.099 & 16.052 & 16.097 & NA & NA & NA & NA & NA & NA \\
\hline
\end{tabular}


Table 4 (continued).

\begin{tabular}{|c|c|c|c|c|c|c|c|c|c|c|c|}
\hline & $\begin{array}{c}849 \\
\text { (t) }\end{array}$ & $\begin{array}{l}849 \\
\text { (o) }\end{array}$ & $\begin{array}{c}850 \\
(t)\end{array}$ & $\begin{array}{l}850 \\
\text { (o) }\end{array}$ & $\begin{array}{c}851 \\
\text { (t) }\end{array}$ & $\begin{array}{l}851 \\
\text { (o) }\end{array}$ & $\begin{array}{c}852 \\
\text { (t) }\end{array}$ & $\begin{array}{l}852 \\
\text { (o) }\end{array}$ & $\begin{array}{c}853 \\
\text { (t) }\end{array}$ & $\begin{array}{l}853 \\
\text { (o) }\end{array}$ & $\begin{array}{c}854 \\
(t)\end{array}$ \\
\hline t $N$, reinholdii & 0.361 & 0.936 & 0.363 & 0.635 & 0.487 & 0.699 & 0.275 & 0.677 & NA & $\mathrm{NA}$ & NA \\
\hline t N. fossilis & 0.942 & 1.110 & 0.714 & 0.898 & 0.784 & 1.050 & 0.275 & 0.677 & NA & NA & NA \\
\hline $\mathrm{t}$ R. matusama & 0.942 & 1.110 & NA & $\mathrm{NA}$ & NA & NA & NA & NA & NA & $\mathrm{NA}$ & NA \\
\hline b R. matuyama & 1.110 & 1.239 & NA & $\mathrm{NA}$ & NA & NA & NA & NA & NA & $\mathrm{NA}$ & $\mathrm{NA}$ \\
\hline $\mathrm{t} \quad R$, praebergonii var. robusta & 1.700 & 1.741 & NA & NA & 1.660 & 1.749 & 1.868 & 2.303 & NA & NA & NA \\
\hline b P. dolius & 1.957 & 2.051 & 2.126 & 2.138 & 1.749 & 1.918 & 1.868 & 2.303 & NA & NA & $\mathrm{NA}$ \\
\hline t T. convexa & 2.380 & 2.622 & 2.359 & 2.403 & 2.338 & 2.441 & 2.303 & 2.493 & NA & $\mathrm{NA}$ & NA \\
\hline t N. jouseae & 2.733 & 2.850 & 2.765 & 2.844 & 2.765 & 2.826 & 2.493 & 2.852 & NA & NA & NA \\
\hline b $R$. praebergonii & 3.141 & 3.217 & 3.253 & 3.352 & 3.042 & 3.147 & 3.134 & 3.778 & NA & NA & NA \\
\hline b $T$. convexa f. convexa & 3.764 & 3.875 & 3.799 & 4.200 & 3.784 & 3.873 & 3.824 & 4.290 & NA & NA & NA \\
\hline b A. elegans & NA & $\mathrm{NA}$ & 3.500 & 3.994 & 3.946 & 4.505 & $\mathrm{NA}$ & NA & NA & $\mathrm{NA}$ & NA \\
\hline t $N$, cylindrica & 4.934 & 4.993 & 4.704 & 4.939 & 4.691 & 4.797 & 4.991 & 5.081 & NA & NA & NA \\
\hline b $N$. jouseae & 5.159 & 5.226 & 4.939 & 5.268 & 4.797 & 4.876 & 4.991 & $5.08 \mathrm{I}$ & NA & NA & NA \\
\hline 1 T. miocenica & 5.812 & 5.864 & 5.809 & 5.835 & 5.589 & 5.677 & NA & NA & NA & NA & NA \\
\hline b $T$. oestrupii & NA & NA & NA & NA & $\mathrm{NA}$ & NA & NA & NA & NA & $\mathrm{NA}$ & NA \\
\hline I N. miocenica & 6.053 & 6.065 & 6.049 & 6.074 & 6.069 & 6.135 & 5.993 & 6.222 & NA & NA & NA \\
\hline t N. miocena var. elongata & 6.053 & 6.065 & NA & NA & 6.195 & 6.215 & $\mathrm{NA}$ & NA & $\mathrm{NA}$ & NA & $\mathrm{NA}$ \\
\hline $\mathrm{t} T$. praeconvexa & 6.053 & 6.065 & 6.210 & 6.227 & 6.323 & 6.454 & $\mathrm{NA}$ & NA & NA & NA & NA \\
\hline t R. praepaleacea & NA & NA & NA & NA & $\mathrm{NA}$ & NA & NA & NA & NA & $\mathrm{NA}$ & $\mathrm{NA}$ \\
\hline b $T$. miocenica & 6.492 & 6.522 & 6.578 & 6.604 & 6.404 & 6.484 & NA & NA & NA & NA & NA \\
\hline b $T$. convexa var, aspinosa & 6.492 & 6.522 & 6.578 & 6.604 & NA & NA & NA & NA & NA & NA & NA \\
\hline b $T$. praeconvexa & 6.713 & 6.835 & 6.645 & 6.665 & 6.597 & 6.802 & NA & NA & NA & $\mathrm{NA}$ & NA \\
\hline I N.porteri & NA & NA & NA & NA & $\mathrm{NA}$ & NA & NA & NA & NA & $\mathrm{NA}$ & NA \\
\hline b N.miocenica & 7.235 & 7.314 & 7.314 & 7.348 & 7.174 & 7.296 & 6.760 & 6.843 & NA & NA & NA \\
\hline t R. paleacea & NA & NA & 7.348 & 7.383 & 7.296 & 7.341 & NA & NA & NA & NA & NA \\
\hline t T. burckliana & 8.270 & 8.308 & 7.651 & 7.956 & NA & $\mathrm{NA}$ & $\mathrm{NA}$ & NA & NA & NA & NA \\
\hline b $N$, reinholdii & 7.573 & 7.867 & NA & NA & NA & NA & NA & NA & NA & NA & NA \\
\hline t A. ellipticus var. javanicus & 7.507 & 7.783 & 7.853 & 7.875 & 7.890 & 8.306 & 7.477 & 7.588 & $\mathrm{NA}$ & NA & NA \\
\hline b $N$ marina & NA & NA & 7.875 & 7.956 & NA & NA & NA & NA & NA & NA & NA \\
\hline b N. cylindrica & 8.008 & 8.098 & 7.974 & 8.034 & 8.070 & 8.463 & 7.951 & 8.028 & NA & $\mathrm{NA}$ & NA \\
\hline t T. yabei & 8.270 & 8.308 & 8.034 & 8.194 & 8.070 & 8.463 & 7.951 & 8.028 & $\mathrm{NA}$ & NA & NA \\
\hline b A. nodulifer var. cyclops & NA & NA & NA & NA & $\mathrm{NA}$ & NA & $\mathrm{NA}$ & NA & $\mathrm{NA}$ & $\mathrm{NA}$ & $\mathrm{NA}$ \\
\hline I C. loeblichii & NA & NA & NA & NA & $\mathrm{NA}$ & NA & $\mathrm{NA}$ & $\mathrm{NA}$ & NA & $\mathrm{NA}$ & $\mathrm{NA}$ \\
\hline b $N$. fossilis & NA & NA & NA & NA & NA & NA & $\mathrm{NA}$ & $\mathrm{NA}$ & NA & $\mathrm{NA}$ & $\mathrm{NA}$ \\
\hline b $T$ burckliana & 8.270 & 8.308 & 8.744 & 9.033 & NA & $\mathrm{NA}$ & NA & NA & $\mathrm{NA}$ & NA & NA \\
\hline b C. loeblichii & NA & NA & NA & $\mathrm{NA}$ & NA & NA & NA & NA & NA & $\mathrm{NA}$ & NA \\
\hline t D. hustedtii & 8.798 & 9.520 & 9.196 & 9.258 & 9.372 & 9.505 & 9.141 & 9.470 & NA & NA & NA \\
\hline $\mathrm{t}$ A. moronensis & NA & NA & 9.332 & 9.401 & 9.558 & 9.753 & NA & NA & NA & NA & NA \\
\hline b A. ellipticus f. lanceolata & NA & NA & NA & NA & NA & NA & $\mathrm{NA}$ & NA & $\mathrm{NA}$ & $\mathrm{NA}$ & $\mathrm{NA}$ \\
\hline b $R$. paleacea var, convexa & NA & NA & NA & NA & NA & NA & NA & NA & NA & NA & NA \\
\hline t C. gigas v. diorama & NA & NA & NA & NA & $\mathrm{NA}$ & NA & NA & NA & NA & $\mathrm{NA}$ & NA \\
\hline t $S$. jouseana & NA & NA & NA & NA & NA & NA & NA & NA & NA & NA & $\mathrm{NA}$ \\
\hline t C. coscinodiscus & NA & NA & 11.238 & 11.308 & 11.180 & 11.363 & NA & NA & $\mathrm{NA}$ & $\mathrm{NA}$ & NA \\
\hline $\mathrm{t}$ A. ingens & NA & NA & NA & NA & NA & NA & NA & NA & NA & NA & NA \\
\hline t C. pulchellus & NA & NA & NA & $\mathrm{NA}$ & NA & $\mathrm{NA}$ & $\mathrm{NA}$ & NA & $\mathrm{NA}$ & NA & $\mathrm{NA}$ \\
\hline t N. porteri & NA & NA & NA & NA & NA & $\mathrm{NA}$ & $\mathrm{NA}$ & NA & NA & NA & NA \\
\hline b $T$, brimii & NA & NA & NA & NA & NA & NA & NA & NA & NA & NA & NA \\
\hline b C. gigas v diorama & NA & NA & NA & NA & NA & NA & NA & $\mathrm{NA}$ & NA & $\mathrm{NA}$ & NA \\
\hline $\mathrm{t}$ A. californicus & NA & NA & NA & NA & NA & NA & NA & NA & NA & NA & NA \\
\hline t C. lewisiamus & NA & NA & NA & NA & NA & NA & $\mathrm{NA}$ & $\mathrm{NA}$ & NA & NA & $\mathrm{NA}$ \\
\hline I T. tappanae & NA & NA & NA & NA & NA & NA & NA & NA & NA & NA & NA \\
\hline b T. cinnamoneram & NA & NA & NA & $\mathrm{NA}$ & NA & NA & NA & NA & NA & NA & NA \\
\hline b D. simonsenii & NA & NA & NA & $\mathrm{NA}$ & NA & NA & NA & NA & NA & NA & NA \\
\hline I C.peplum & NA & NA & NA & NA & NA & NA & $\mathrm{NA}$ & $\mathrm{NA}$ & NA & NA & NA \\
\hline b A. ellipticus & NA & NA & NA & NA & NA & NA & NA & NA & NA & NA & NA \\
\hline b C. blysmos & NA & NA & NA & NA & NA & NA & NA & $\mathrm{NA}$ & $\mathrm{NA}$ & $\mathrm{NA}$ & $\mathrm{NA}$ \\
\hline t A. californicus & NA & NA & NA & NA & NA & NA & NA & NA & NA & NA & NA \\
\hline b A. ingens & NA & NA & NA & $\mathrm{NA}$ & NA & NA & NA & $\mathrm{NA}$ & $\mathrm{NA}$ & NA & NA \\
\hline t C. lewisiamus var, similis & NA & NA & NA & NA & NA & NA & NA & NA & NA & $\mathrm{NA}$ & $\mathrm{NA}$ \\
\hline I T. fraga & NA & NA & NA & NA & NA & NA & NA & NA & NA & NA & NA \\
\hline b C. peplum & NA & NA & NA & NA & $\mathrm{NA}$ & NA & NA & NA & $\mathrm{NA}$ & NA & NA \\
\hline $\mathrm{t} \quad R$. marylandicus & NA & NA & NA & NA & NA & NA & NA & NA & NA & NA & NA \\
\hline b $C$. coscinodiscus ss. & NA & NA & NA & $\mathrm{NA}$ & $\mathrm{NA}$ & $\mathrm{NA}$ & NA & $\mathrm{NA}$ & NA & NA & $\mathrm{NA}$ \\
\hline b C. nicobarica & NA & NA & NA & NA & NA & NA & NA & NA & NA & NA & NA \\
\hline b E. huxleyi & NA & $\mathrm{NA}$ & NA & NA & NA & NA & NA & NA & NA & NA & NA \\
\hline t P. lacunosa & 0.401 & 0.441 & 0.407 & 0.458 & 0.344 & 0.364 & 0.415 & 0.490 & 0.728 & 0.749 & 0.440 \\
\hline b Reentry medium Gephyrocapsa spp. & 1.003 & 1.042 & 0.957 & 1.008 & 1.001 & 1.024 & 0.979 & 1.040 & 0.978 & 1.082 & 0.957 \\
\hline t Large Gephyrocapsa spp. & 1.199 & 1.233 & 1.240 & 1.293 & 1.250 & 1.266 & 1.209 & 1.263 & NA & NA & NA \\
\hline b Large Gephyrocapsa spp. & 1.368 & 1.412 & 1.394 & 1.435 & 1.430 & 1.450 & 1.513 & 1.561 & 1.314 & 1.499 & NA \\
\hline t C. macintyrei & 1.564 & 1.588 & 1.545 & 1.599 & 1.555 & 1.620 & 1.669 & 1.747 & 1.499 & 1.605 & 1.586 \\
\hline b G. oceanica sl. & 1.698 & 1.709 & 1.700 & 1.832 & 1.660 & 1.723 & 1.669 & 1.747 & 1.644 & 1.712 & 1.586 \\
\hline t D. brouweri & 2.052 & 2.058 & 2.140 & 2.149 & 1.950 & 1.976 & 1.807 & 1.898 & 1.712 & 1.793 & $\mathrm{NA}$ \\
\hline $\mathrm{t}$ D. pentaradiatus & $\mathrm{NA}$ & NA & NA & NA & NA & $\mathrm{NA}$ & 2.490 & 2.548 & 2.370 & 2.469 & 2.384 \\
\hline t D. surculus & 2.486 & 2.536 & 2.612 & 2.702 & 2.758 & 2.765 & 2.818 & 2.870 & 2.715 & 2.744 & 2.515 \\
\hline $\mathrm{t}$ D. tamalis & 2.752 & 2.760 & 2.750 & 2.768 & 2.758 & 2.765 & 2.928 & 2.991 & 2.804 & 3.071 & $\mathrm{NA}$ \\
\hline t S. abies & 3.646 & 3.692 & 3.675 & 3.720 & 3.551 & 3.623 & 3.593 & 3.672 & 3.874 & 3.907 & $\mathrm{NA}$ \\
\hline $\mathrm{t} R$. pseudoumbilicus & 3.788 & 3.792 & 3.799 & 3.807 & 3.788 & 3.817 & 3.781 & 3.841 & 3.874 & 3.907 & 3.725 \\
\hline be D. asymmetricus & $\mathrm{NA}$ & NA & NA & $\mathrm{NA}$ & 3.908 & 4.054 & 3.875 & 3.926 & 4.130 & 4.311 & NA \\
\hline $\mathrm{t}$ A. primus & $\mathrm{NA}$ & $\mathrm{NA}$ & 4.554 & 4.687 & 4.598 & 4.648 & 4.471 & 4.680 & 4.545 & 4.615 & $\mathrm{NA}$ \\
\hline t C. acutus & NA & $\mathrm{NA}$ & 4.939 & 5.031 & 4.972 & 4.982 & 4.939 & 4.965 & 4.966 & 5.063 & $\mathrm{NA}$ \\
\hline b C. rugosus & 5.055 & 5.075 & 5.031 & 5.047 & 4.972 & 4.982 & 4.905 & 4.939 & 5.063 & 5.090 & NA \\
\hline b $\quad C$. acutus & 5.340 & 5.354 & 5.333 & 5.342 & 5.356 & 5.377 & 5.307 & 5.332 & 5.321 & 5.370 & NA \\
\hline t T. rugosus & 5.340 & 5.354 & NA & NA & NA & NA & NA & NA & NA & $\mathrm{NA}$ & NA \\
\hline $\mathrm{t}$ D. quinqueramus & 5.595 & 5.600 & 5.605 & 5.620 & 5.550 & 5.558 & 5.494 & 5.536 & 5.321 & 5.370 & 3.725 \\
\hline t Circular reticulofenestrids & NA & NA & 6.224 & 6.246 & NA & NA & NA & NA & $\mathrm{NA}$ & NA & NA \\
\hline t A. amplificus & 6.050 & 6.056 & 6.008 & 6.028 & 5.853 & 5.902 & 5.897 & 5.993 & 5.860 & 5.904 & NA \\
\hline
\end{tabular}


Table 4 (continued).

\begin{tabular}{|c|c|c|c|c|c|c|c|c|c|c|c|}
\hline & $\begin{array}{l}849 \\
(\mathrm{t})\end{array}$ & $\begin{array}{l}849 \\
\text { (o) }\end{array}$ & $\begin{array}{c}850 \\
(\mathrm{t})\end{array}$ & $\begin{array}{l}850 \\
\text { (o) }\end{array}$ & $\begin{array}{c}851 \\
(t)\end{array}$ & $\begin{array}{l}851 \\
\text { (o) }\end{array}$ & $\begin{array}{c}852 \\
(t)\end{array}$ & $\begin{array}{l}852 \\
\text { (o) }\end{array}$ & $\begin{array}{c}853 \\
\text { (t) }\end{array}$ & $\begin{array}{l}853 \\
(0)\end{array}$ & $\begin{array}{c}854 \\
\text { (t) }\end{array}$ \\
\hline b A. amplificus & 6.098 & 6.120 & 6.302 & 6.336 & 6.462 & 6.501 & 6.551 & 6.687 & 6.539 & 6.570 & NA \\
\hline b Circular reticulofenestrids & $\mathrm{NA}$ & NA & 6.792 & 6.828 & $\mathrm{NA}$ & NA & NA & NA & NA & NA & NA \\
\hline t Absence $R$, pseudoumbilicus & 6.256 & 6.265 & 6.518 & 6.522 & 7.001 & 7.034 & 6.687 & 6.779 & 6.671 & 6.773 & NA \\
\hline b A. primus & 6.878 & 6.937 & 6.828 & 6.885 & 7.212 & 7.226 & 7.179 & 7.245 & 7.118 & 7.176 & NA \\
\hline M. convallis & $\mathrm{NA}$ & $\mathrm{NA}$ & NA & NA & 7.218 & 7.229 & $\mathrm{NA}$ & NA & NA & NA & NA \\
\hline b D. berggrenii & 7.521 & 7.538 & 7.383 & 7.418 & 7.890 & 7.963 & 8.061 & 8.079 & 8.238 & 8.253 & 5.994 \\
\hline b D. pentaradiatus & $\mathrm{NA}$ & NA & $\mathrm{NA}$ & NA & NA & NA & 8.405 & 8.439 & NA & NA & NA \\
\hline b D. loeblichi & NA & NA & 8.390 & 8.421 & 8.404 & 8.431 & 8.439 & 8.470 & NA & NA & NA \\
\hline b Absence $R$. pseudoumbilicus & 9.058 & 9.119 & 8.847 & 8.876 & 8.554 & 8.777 & 8.630 & 8.755 & NA & NA & NA \\
\hline D. hamatus & 9.190 & 9.251 & 9.444 & 9.492 & 9.460 & 9.472 & 9.274 & 9.386 & NA & NA & NA \\
\hline b $M$. convallis & 9.058 & 9.119 & 9.492 & 9.517 & 9.499 & 9.550 & 9.274 & 9.386 & NA & NA & NA \\
\hline b D. neohamatus & 9.545 & 9.593 & 9.444 & 9.492 & 9.656 & 9.674 & 9.414 & 9.479 & NA & NA & NA \\
\hline b C. coalitus & NA & NA & NA & NA & 10.806 & 10.823 & NA & NA & NA & NA & NA \\
\hline b D, hamatus & 10.173 & 10.275 & 10.512 & 10.513 & 10.490 & 10.501 & 10.674 & 10.685 & NA & NA & NA \\
\hline t C. miopelagicus & 10.376 & 10.473 & 10.531 & 10.563 & 10.501 & 10.510 & 10.685 & 10.727 & NA & NA & NA \\
\hline t C.floridanus & $\mathrm{NA}$ & $\mathrm{NA}$ & NA & NA & $\mathrm{NA}$ & $\mathrm{NA}$ & $\mathrm{NA}$ & NA & NA & NA & NA \\
\hline I C. nitescens & $\mathrm{NA}$ & NA & NA & NA & NA & NA & NA & NA & $\mathrm{NA}$ & NA & NA \\
\hline tc D. kugleri & 11.315 & 11.329 & 11.409 & 11.563 & 11.289 & 11.300 & NA & NA & $\mathrm{NA}$ & NA & NA \\
\hline bc $D$. kugleri & NA & NA & NA & NA & 11.692 & 11.709 & NA & $\mathrm{NA}$ & NA & NA & NA \\
\hline b D. kugleri & $\mathrm{NA}$ & NA & NA & NA & NA & NA & NA & NA & NA & NA & NA \\
\hline b C. macintyrei & NA & $\mathrm{NA}$ & NA & NA & NA & NA & NA & $\mathrm{NA}$ & NA & NA & NA \\
\hline C. premacintyrei & NA & NA & NA & NA & NA & NA & NA & NA & $\mathrm{NA}$ & NA & NA \\
\hline b $T$, rugosus & NA & NA & NA & NA & $\mathrm{NA}$ & NA & NA & NA & NA & $\mathrm{NA}$ & NA \\
\hline I D. signus & NA & NA & NA & NA & NA & NA & NA & NA & NA & NA & NA \\
\hline b $R$. pseudoumbilicus & $\mathrm{NA}$ & NA & NA & $\mathrm{NA}$ & $\mathrm{NA}$ & $\mathrm{NA}$ & NA & NA & NA & NA & NA \\
\hline t S. heteromorphus & $\mathrm{NA}$ & NA & NA & NA & NA & NA & NA & NA & NA & NA & NA \\
\hline t H. ampliapertura & NA & $\mathrm{NA}$ & NA & NA & NA & $\mathrm{NA}$ & NA & NA & NA & NA & NA \\
\hline b D. signus & NA & $\mathrm{NA}$ & NA & $\mathrm{NA}$ & NA & NA & NA & NA & NA & NA & NA \\
\hline Acme D. deflandrei & $\mathrm{NA}$ & NA & NA & NA & NA & $\mathrm{NA}$ & NA & NA & $\mathrm{NA}$ & NA & NA \\
\hline t $S$. universus & 0.397 & 0.505 & 0.402 & 0.582 & 0.320 & 0.373 & 0.384 & 0.444 & 0.000 & 0.269 & 0.497 \\
\hline b C. tuberosa & 0.583 & 0.813 & 0.582 & 0.635 & 0.487 & 0.651 & 0.532 & 0.768 & 0.000 & 0.269 & 0.497 \\
\hline t L neoheteroporos & 0.957 & 1.042 & 1.003 & 1.128 & 1.112 & 1.182 & 1.114 & 1.150 & 1.082 & 1.295 & 0.783 \\
\hline t. A. angulare & 1.042 & 1.249 & 1.003 & 1.128 & 1.182 & 1.250 & 1.114 & 1.150 & 1.082 & 1.295 & 1.155 \\
\hline$t \quad T$. vetulum & 1.042 & 1.249 & 1.194 & 1.315 & 1.250 & 1.394 & 1.114 & 1.243 & 1.082 & 1.295 & 1.155 \\
\hline b L nigriniae & 1.042 & 1.249 & 1.194 & 1.315 & 1.182 & 1.250 & 1.205 & 1.243 & 1.295 & 1.586 & 1.444 \\
\hline b T. trachelium & 1.428 & 1.543 & 1.461 & 1.628 & 1.660 & 1.780 & 1.756 & 1.803 & 1.295 & 1.586 & 1.444 \\
\hline b P. minithorax & 1.428 & 1.543 & 1.628 & 1.700 & 1.660 & 1.780 & 1.243 & 1.276 & 0.708 & 1.037 & 1.444 \\
\hline b A. angulare & 1.726 & 1.755 & 1.700 & 1.931 & 1.660 & 1.780 & 1.756 & 1.803 & 1.899 & 2.180 & 1.769 \\
\hline $\mathrm{t} \quad P$.prismatium & 1.726 & 1.755 & 1.700 & 1.931 & 1.660 & 1.780 & 1.608 & 1.711 & 1.586 & 1.899 & 1.769 \\
\hline t $L$. heteroporos & 1.543 & 1.609 & 1.461 & 1.628 & 1.562 & 1.660 & 1.608 & 1.711 & 1.586 & 1.899 & 1.549 \\
\hline t A. jenghisi & 2.482 & 2.506 & 2.449 & 2.515 & 2.269 & 2.371 & 2.381 & 2.432 & $\mathrm{NA}$ & NA & 2.115 \\
\hline b $T$. davisiana & 2.622 & 2.807 & 2.653 & 2.729 & 2.726 & 2.765 & 2.741 & 2.764 & NA & NA & 2.490 \\
\hline t $S$.peregrina & 2.622 & 2.807 & 2.729 & 2.855 & 2.726 & 2.765 & 2.764 & 2.813 & NA & NA & 2.490 \\
\hline t A.pliocenica & 3.217 & 3.309 & 3.133 & 3.185 & 3.367 & 3.447 & 3.518 & 3.633 & $\mathrm{NA}$ & $\mathrm{NA}$ & NA \\
\hline b $L$ heteroporos & 3.207 & 3.217 & 2.979 & 3.133 & 2.913 & 2.956 & 3.134 & 3.140 & NA & $\mathrm{NA}$ & NA \\
\hline t L audax & 3.764 & 3.961 & 3.675 & 3.811 & 3.674 & 3.774 & 3.755 & 3.776 & NA & NA & NA \\
\hline t P. fistula & 3.694 & 3.764 & 3.484 & 3.675 & 3.448 & 3.514 & 3.454 & 3.518 & NA & NA & NA \\
\hline b $L$ neoheteroporos & 3.207 & 3.217 & 2.979 & 3.133 & 2.913 & 2.956 & 3.134 & 3.140 & NA & NA & NA \\
\hline t P. dolium & 3.764 & 3.961 & 3.811 & 3.948 & 3.774 & 3.946 & 3.810 & 3.947 & NA & NA & NA \\
\hline b A. ypsilon & 3.961 & 4.003 & 3.811 & 3.948 & 3.946 & 4.103 & 3.998 & 4.057 & NA & NA & $\mathrm{NA}$ \\
\hline t D. penultima & 4.174 & 4.323 & 4.200 & 4.320 & 4.151 & 4.268 & 4.115 & 4.181 & NA & NA & NA \\
\hline b S. tetras & 4.174 & 4.323 & 4.200 & 4.320 & 4.151 & 4.268 & 4.115 & 4.181 & NA & NA & NA \\
\hline b $P$. prismatium & 4.737 & 4.746 & 4.762 & 4.842 & 4.505 & 4.877 & 4.492 & 4.983 & NA & NA & NA \\
\hline I $S$ omnitubus & 5.385 & 5.419 & 5.360 & 5.393 & 5.373 & 5.454 & 4.983 & 5.076 & NA & NA & $\mathrm{NA}$ \\
\hline t S. corona & 5.586 & 5.622 & 5.754 & 5.758 & 5.791 & 5.830 & 5.897 & 6.055 & NA & NA & NA \\
\hline t $S$. johnsoni & 6.230 & 6.326 & 6.313 & 6.375 & 6.245 & 6.282 & 6.244 & 6.275 & NA & NA & NA \\
\hline b $S$. delmontensis to $S$. peregrina & 6.652 & 6.682 & 6.645 & 6.670 & 6.633 & 6.678 & 6.816 & 6.837 & NA & NA & NA \\
\hline t C. caepa & 6.230 & 6.326 & 6.313 & 6.375 & 6.282 & 6.329 & 6.771 & 6.795 & NA & NA & $\mathrm{NA}$ \\
\hline b $S$. omnitubus & 6.970 & 7.072 & 7.116 & 7.168 & 6.802 & 7.012 & 7.204 & 7.275 & NA & NA & $\mathrm{NA}$ \\
\hline t D. hughesi & 7.617 & 7.841 & 7.710 & 7.781 & 7.518 & 7.721 & 7.620 & 7.661 & NA & $\mathrm{NA}$ & $\mathrm{NA}$ \\
\hline b $S$. berminghami & $\mathrm{NA}$ & NA & NA & NA & NA & $\mathrm{NA}$ & NA & $\mathrm{NA}$ & NA & NA & NA \\
\hline t $S$. wolffi & 8.900 & 9.030 & 8.824 & 9.033 & 8.942 & 8.976 & 9.113 & 9.163 & NA & NA & NA \\
\hline t B. miralestensis & 8.208 & 8.346 & 8.194 & 8.349 & 8.126 & 8.271 & 8.070 & 8.106 & NA & NA & $\mathrm{NA}$ \\
\hline D. pettersoni & 8.208 & 8.346 & 8.350 & 8.404 & 8.271 & 8.306 & 8.378 & 8.531 & $\mathrm{NA}$ & NA & NA \\
\hline b D. hughesi & 8.208 & 8.346 & 8.824 & 9.033 & 8.867 & 8.942 & 8.981 & 9.113 & NA & NA & NA \\
\hline b $D$. pettersoni to $D$. hughesi & 8.525 & 8.623 & 8.594 & 8.744 & 8.572 & 8.821 & 8.889 & 8.973 & NA & $\mathrm{NA}$ & $\mathrm{NA}$ \\
\hline t C. japonica & 9.881 & 10.207 & 10.119 & 10.187 & 10.054 & 10.120 & 9.946 & 10.054 & NA & NA & NA \\
\hline t C. cristata & 10.771 & 10.877 & 10.637 & 10.702 & 10.638 & 10.711 & NA & $\mathrm{NA}$ & NA & NA & NA \\
\hline t $L$ thomburgi & 9.881 & 10.207 & 9.332 & 9.678 & 10.120 & 10.132 & NA & NA & NA & NA & $\mathrm{NA}$ \\
\hline i L renzae & NA & NA & NA & NA & NA & NA & NA & NA & NA & NA & $\mathrm{NA}$ \\
\hline t C. cornuta & $\mathrm{NA}$ & $\mathrm{NA}$ & NA & $\mathrm{NA}$ & NA & NA & $\mathrm{NA}$ & $\mathrm{NA}$ & NA & NA & $\mathrm{NA}$ \\
\hline b $D$, pettersoni & NA & NA & NA & $\mathrm{NA}$ & NA & $\mathrm{NA}$ & NA & NA & NA & NA & $\mathrm{NA}$ \\
\hline D. alata & $\mathrm{NA}$ & $\mathrm{NA}$ & NA & NA & NA & NA & NA & $\mathrm{NA}$ & NA & NA & $\mathrm{NA}$ \\
\hline b $\quad C$. japonica & $\mathrm{NA}$ & $\mathrm{NA}$ & NA & $\mathrm{NA}$ & NA & NA & NA & NA & NA & $\mathrm{NA}$ & NA \\
\hline b C. caepa & $\mathrm{NA}$ & $\mathrm{NA}$ & NA & NA & NA & NA & NA & NA & NA & NA & NA \\
\hline b $L$ thornburgi & $\mathrm{NA}$ & NA & $\mathrm{NA}$ & $\mathrm{NA}$ & NA & $\mathrm{NA}$ & $\mathrm{NA}$ & NA & $\mathrm{NA}$ & NA & $\mathrm{NA}$ \\
\hline t $S$ armata & $\mathrm{NA}$ & NA & $\mathrm{NA}$ & NA & NA & NA & NA & NA & NA & NA & $\mathrm{NA}$ \\
\hline t $L$ parkerae & NA & NA & NA & NA & NA & $\mathrm{NA}$ & NA & NA & $\mathrm{NA}$ & NA & NA \\
\hline I octopyle & NA & NA & $\mathrm{NA}$ & NA & NA & $\mathrm{NA}$ & NA & $\mathrm{NA}$ & NA & $\mathrm{NA}$ & $\mathrm{NA}$ \\
\hline t C. bramlettei & $\mathrm{NA}$ & NA & NA & $\mathrm{NA}$ & NA & $\mathrm{NA}$ & $\mathrm{NA}$ & NA & NA & $\mathrm{NA}$ & $\mathrm{NA}$ \\
\hline C costata & NA & NA & NA & $\mathrm{NA}$ & NA & $\mathrm{NA}$ & NA & NA & NA & $\mathrm{NA}$ & $\mathrm{NA}$ \\
\hline b D. dentata to $D$. alata & $\mathrm{NA}$ & NA & NA & NA & NA & NA & NA & NA & NA & NA & NA \\
\hline t L stauropora & NA & NA & NA & NA & NA & $\mathrm{NA}$ & NA & NA & NA & NA & $\mathrm{NA}$ \\
\hline b $L$ parkerae & $\mathrm{NA}$ & NA & $\mathrm{NA}$ & NA & $\mathrm{NA}$ & $\mathrm{NA}$ & NA & NA & NA & $\mathrm{NA}$ & $\mathrm{NA}$ \\
\hline t $S$. diaphenes & $\mathrm{NA}$ & NA & NA & NA & NA & $\mathrm{NA}$ & $\mathrm{NA}$ & NA & $\mathrm{NA}$ & NA & NA \\
\hline b C. bramlettei & $\mathrm{NA}$ & NA & NA & NA & NA & $\mathrm{NA}$ & NA & NA & NA & NA & NA \\
\hline
\end{tabular}


Table 4 (continued).

\begin{tabular}{|c|c|c|c|c|c|c|c|c|c|c|c|c|c|}
\hline & & $\begin{array}{c}849 \\
\text { (t) }\end{array}$ & $\begin{array}{l}849 \\
\text { (o) }\end{array}$ & $\begin{array}{c}850 \\
\text { (t) }\end{array}$ & $\begin{array}{l}850 \\
\text { (o) }\end{array}$ & $\begin{array}{c}851 \\
\text { (t) }\end{array}$ & $\begin{array}{l}851 \\
\text { (o) }\end{array}$ & $\begin{array}{c}852 \\
\text { (t) }\end{array}$ & $\begin{array}{l}852 \\
\text { (o) }\end{array}$ & $\begin{array}{c}853 \\
\text { (t) }\end{array}$ & $\begin{array}{l}853 \\
\text { (o) }\end{array}$ & $\begin{array}{c}854 \\
\text { (t) }\end{array}$ & $\begin{array}{l}854 \\
\text { (o) }\end{array}$ \\
\hline b & A. octopyle & NA & NA & NA & NA & NA & NA & NA & NA & NA & NA & NA & NA \\
\hline$t$ & C. cingulata & NA & NA & NA & NA & $\mathrm{NA}$ & NA & NA & NA & NA & $\mathrm{NA}$ & NA & NA \\
\hline $\mathrm{t}$ & D. prismatica & NA & NA & NA & NA & NA & NA & NA & NA & NA & NA & NA & NA \\
\hline b & G. toxaria & NA & NA & NA & NA & NA & NA & NA & $\mathrm{NA}$ & NA & NA & NA & NA \\
\hline$t$ & G. tosaensis & NA & $\mathrm{NA}$ & NA & NA & NA & $\mathrm{NA}$ & NA & NA & $\mathrm{NA}$ & NA & NA & NA \\
\hline$t$ & Pulleniatina $\mathrm{L}$ & NA & NA & NA & NA & NA & NA & NA & NA & NA & NA & NA & NA \\
\hline$t$ & G. fistulosus & 1.837 & 1.840 & NA & NA & 1.660 & 2.269 & NA & NA & $\mathrm{NA}$ & $\mathrm{NA}$ & NA & $\mathrm{NA}$ \\
\hline b & G. truncatulinoides & NA & NA & NA & NA & NA & NA & NA & NA & NA & NA & NA & NA \\
\hline $\mathrm{t}$ & G. obliquus & NA & NA & $\mathrm{NA}$ & NA & 2.765 & 3.367 & NA & NA & NA & NA & NA & NA \\
\hline$t$ & G. limbata & 2.151 & 2.622 & 1.447 & 2.010 & 1.660 & 2.269 & 1.608 & 2.548 & 1.082 & 2.880 & NA & NA \\
\hline $\mathrm{t}$ & G. altispira & 3.420 & 3.764 & 2.449 & 2.979 & 2.765 & 3.367 & NA & NA & NA & NA & NA & NA \\
\hline $\mathrm{t}$ & S. seminulina & 3.420 & 3.764 & 2.449 & 2.979 & 2.765 & 3.367 & 3.518 & 4.492 & 1.082 & 2.880 & NA & NA \\
\hline $\mathrm{t}$ & P. spectabilis & NA & NA & NA & NA & NA & $\mathrm{NA}$ & NA & $\mathrm{NA}$ & NA & NA & NA & NA \\
\hline b & G. tumida & NA & $\mathrm{NA}$ & NA & NA & 5.261 & 5.549 & 7.275 & 8.028 & 5.090 & 6.108 & NA & $\mathrm{NA}$ \\
\hline $\mathrm{t}$ & G. dehiscens & NA & NA & NA & NA & $\mathrm{NA}$ & NA & NA & NA & NA & NA & $\mathrm{NA}$ & NA \\
\hline$t$ & G. siakensis & NA & NA & NA & NA & 10.856 & 11.180 & 8.602 & 10.773 & NA & NA & NA & NA \\
\hline $\mathrm{t}$ & G. fohsi group & NA & NA & NA & NA & NA & $\mathrm{NA}$ & $\mathrm{NA}$ & $\mathrm{NA}$ & NA & NA & NA & NA \\
\hline b & G. fohsi lobata & NA & NA & NA & NA & NA & $\mathrm{NA}$ & NA & NA & NA & NA & NA & $\mathrm{NA}$ \\
\hline b & G. fohsi fohsi & NA & NA & NA & NA & NA & NA & NA & NA & NA & NA & NA & NA \\
\hline$t$ & G. archaeomenardii & NA & NA & NA & NA & NA & NA & NA & NA & NA & NA & NA & NA \\
\hline b & G. praefohsi & NA & NA & NA & NA & NA & $\mathrm{NA}$ & $\mathrm{NA}$ & NA & $\mathrm{NA}$ & NA & NA & NA \\
\hline & O. suturalis & NA & NA & NA & NA & NA & NA & NA & NA & NA & NA & $\mathrm{NA}$ & $\mathrm{NA}$ \\
\hline b & P. sicana & NA & NA & NA & NA & NA & $\mathrm{NA}$ & $\mathrm{NA}$ & NA & NA & NA & NA & NA \\
\hline
\end{tabular}

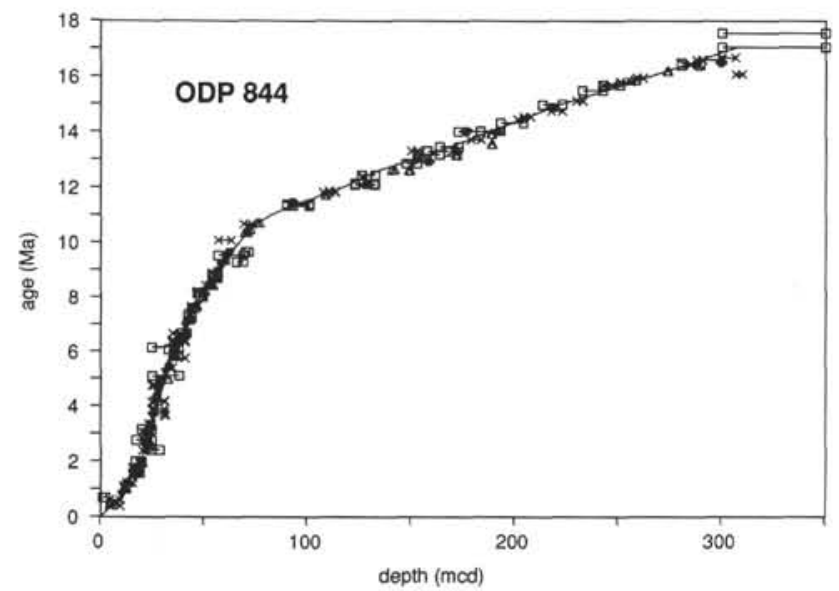

Figure 3. Age-depth plot for Site 844. The line shows the age-depth relationship given by Shackleton et al. (this volume). For each biostratigraphic datum, the upper and lower depth limits are shown at the ages estimated in the column labeled "Best" in Table 6. Symbols as in Figure 1, with the addition of solid triangles $=$ magnetics.

Here, we have examined the data from a biostratigrapher's standpoint. Table 5 (complete table on CD-ROM, back pocket) gives the upper and lower estimates of each datum in each site, with each upper and lower estimate sorted by age. If every age model were perfect, and if every datum were synchronous over the region covered, then every upper bound would be younger than the true age of the event, and every lower bound would be older than the true age. If this were the case, the separation would be an indication only of how closely the biostratigrapher sampled for each datum in each site. In reality, there is some overlap between the oldest upper limit, and the youngest older limit, for virtually every one of the datums. This overlap, which we call raw diachrony, is estimated in Table 6 (column labeled "Best") for each datum considered. Several factors certainly contribute to this raw diachrony. First, it is probable that not all datums should be regarded as synchronous; Moore et al. (1993), taking an ecologic rather than a biostratigraphic standpoint, demonstrated this for several of the datums discussed here. Second, the placement of several datums is seriously distorted by preservation problems in some sites. Third, some

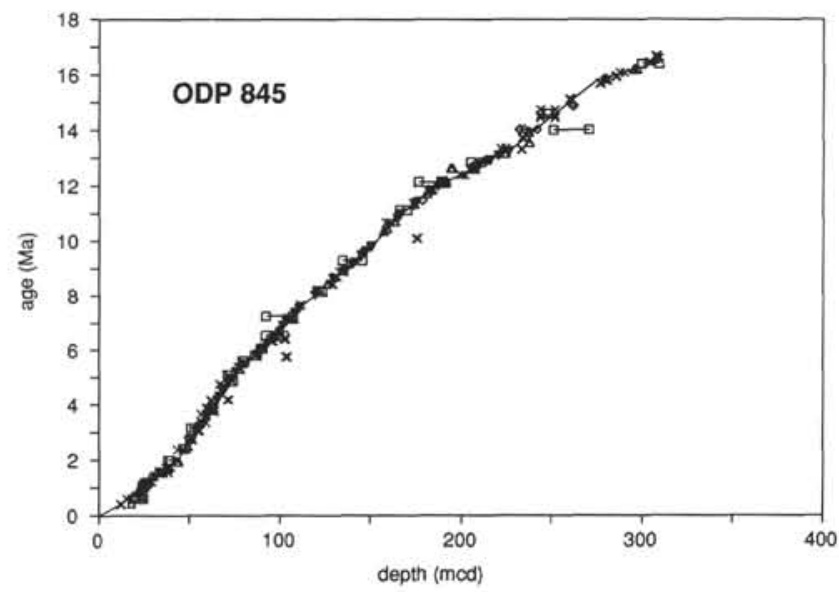

Figure 4. As in Figure 3, for Site 845. Symbols as in Figure 3.

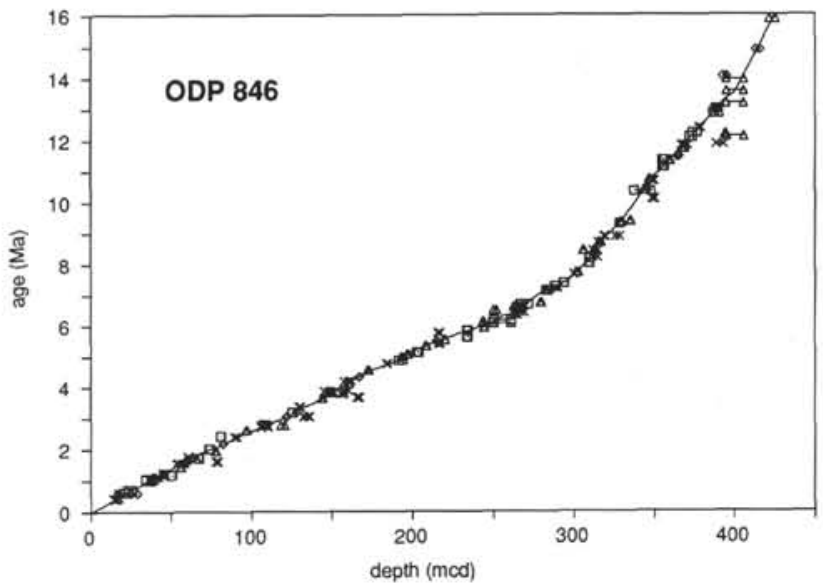

Figure 5. As in Figure 3, for Site 846. Symbols as in Figure 1. 
Table 4 (continued).

\begin{tabular}{|c|c|c|c|c|c|c|c|c|c|c|c|}
\hline & & $\begin{array}{c}844 \\
(t)\end{array}$ & $\begin{array}{l}844 \\
\text { (o) }\end{array}$ & $\begin{array}{l}845 \\
(\mathrm{t})\end{array}$ & $\begin{array}{l}845 \\
\text { (o) }\end{array}$ & $\begin{array}{c}846 \\
(\mathrm{t})\end{array}$ & $\begin{array}{l}846 \\
\text { (o) }\end{array}$ & $\begin{array}{l}847 \\
\text { (t) }\end{array}$ & $\begin{array}{l}847 \\
\text { (o) }\end{array}$ & $\begin{array}{c}848 \\
\text { (t) }\end{array}$ & $\begin{array}{l}848 \\
\text { (o) }\end{array}$ \\
\hline b & A. octopyle & 16.621 & 16.859 & 16.430 & 16.450 & NA & NA & NA & NA & NA & NA \\
\hline t & C. cingulata & 16.481 & 16.554 & 16.348 & 16.362 & $\mathrm{NA}$ & NA & NA & NA & NA & NA \\
\hline t & D. prismatica & 16.859 & 17.019 & 16.415 & 16.430 & $\mathrm{NA}$ & NA & NA & NA & NA & NA \\
\hline b & G. toxaria & 16.554 & 16.621 & NA & NA & $\mathrm{NA}$ & NA & NA & NA & NA & NA \\
\hline $\mathrm{t}$ & G. tosaensis & $\mathrm{NA}$ & NA & NA & $\mathrm{NA}$ & 0.454 & 0.794 & NA & NA & NA & NA \\
\hline$t$ & Pulleniatina $\mathrm{L}$ & $\mathrm{NA}$ & $\mathrm{NA}$ & NA & NA & NA & NA & 0.858 & 1.223 & NA & NA \\
\hline$t$ & G. fistulosus & NA & NA & NA & NA & 1.744 & 1.747 & 1.504 & 1.848 & NA & NA \\
\hline b & G. truncatulinoides & NA & NA & NA & $\mathrm{NA}$ & NA & NA & 2.330 & 2.450 & NA & NA \\
\hline $\mathrm{t}$ & G. obliquus & $\mathrm{NA}$ & $\mathrm{NA}$ & NA & $\mathrm{NA}$ & $\mathrm{NA}$ & NA & 2.450 & 2.801 & NA & NA \\
\hline $\mathrm{t}$ & G. limbata & NA & $\mathrm{NA}$ & NA & NA & 2.175 & 2.178 & 2.330 & 2.450 & 1.746 & 3.411 \\
\hline $\mathrm{t}$ & G. altispira & NA & NA & NA & NA & 3.043 & 3.048 & NA & NA & NA & NA \\
\hline$t$ & S. seminulina & $\mathrm{NA}$ & $\mathrm{NA}$ & NA & $\mathrm{NA}$ & 3.202 & 3.207 & 3.562 & 3.918 & 3.411 & 4.879 \\
\hline $\mathrm{t}$ & P. spectabilis & NA & $\mathrm{NA}$ & NA & $\mathrm{NA}$ & 4.335 & 4.337 & 3.918 & 4.332 & $\mathrm{NA}$ & NA \\
\hline b & G. tumida & $\mathrm{NA}$ & $\mathrm{NA}$ & NA & NA & $\mathrm{NA}$ & NA & 5.368 & 5.605 & NA & NA \\
\hline$t$ & G. dehiscens & NA & $\mathrm{NA}$ & NA & NA & 5.489 & 5.491 & NA & NA & NA & NA \\
\hline$t$ & G. siakensis & NA & NA & $\mathrm{NA}$ & NA & $\mathrm{NA}$ & $\mathrm{NA}$ & $\mathrm{NA}$ & NA & NA & NA \\
\hline$t$ & G. fohsi group & 11.318 & 11.366 & 11.584 & 11.592 & 11.597 & 11.681 & $\mathrm{NA}$ & NA & NA & NA \\
\hline b & G. fohsi lobata & 13.174 & 13.213 & 12.847 & 12.891 & 12.960 & 13.044 & $\mathrm{NA}$ & NA & NA & NA \\
\hline b & G. fohsi fohsi & 13.686 & 13.728 & 13.550 & 13.577 & 13.211 & 13.336 & NA & NA & NA & NA \\
\hline$t$ & G. archaeomenardii & 14.129 & 14.173 & 13.702 & 14.079 & NA & NA & NA & NA & NA & NA \\
\hline b & G. praefohsi & 14.271 & 14.314 & 14.165 & 14.640 & 14.242 & 14.390 & $\mathrm{NA}$ & NA & NA & NA \\
\hline b & O. suturalis & 14.866 & 14.909 & 15.101 & 15.143 & 14.795 & 15.041 & NA & NA & NA & NA \\
\hline b & P. sicana & 16.821 & NA & NA & NA & NA & NA & NA & NA & NA & NA \\
\hline
\end{tabular}

Note: Full generic names appear in Table 6.

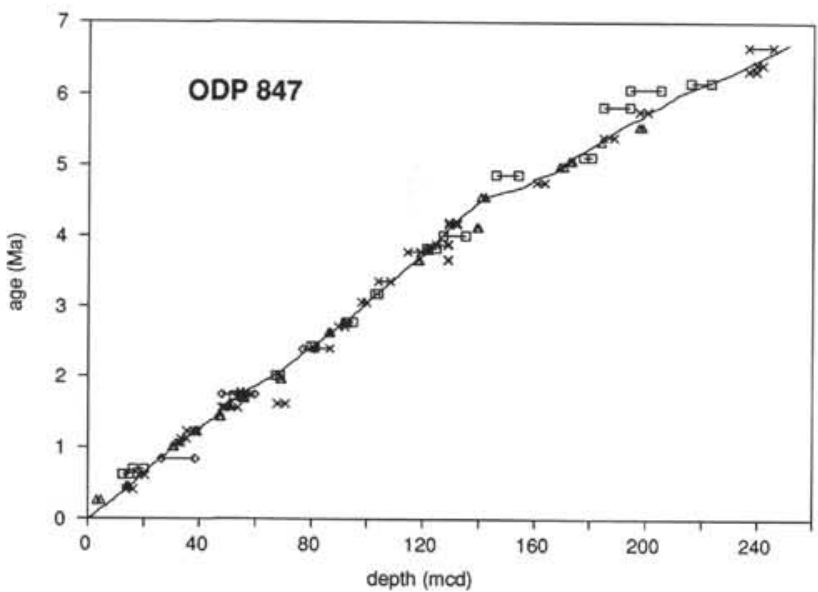

Figure 6. As in Figure 3, for Site 847. Symbols as in Figure 1.

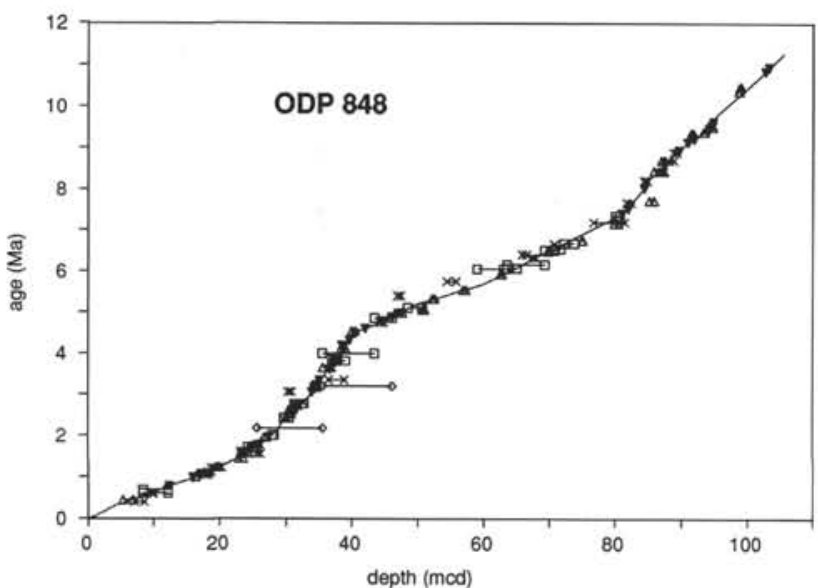

Figure 7. As in Figure 3, for Site 848. Symbols as in Figure 3.

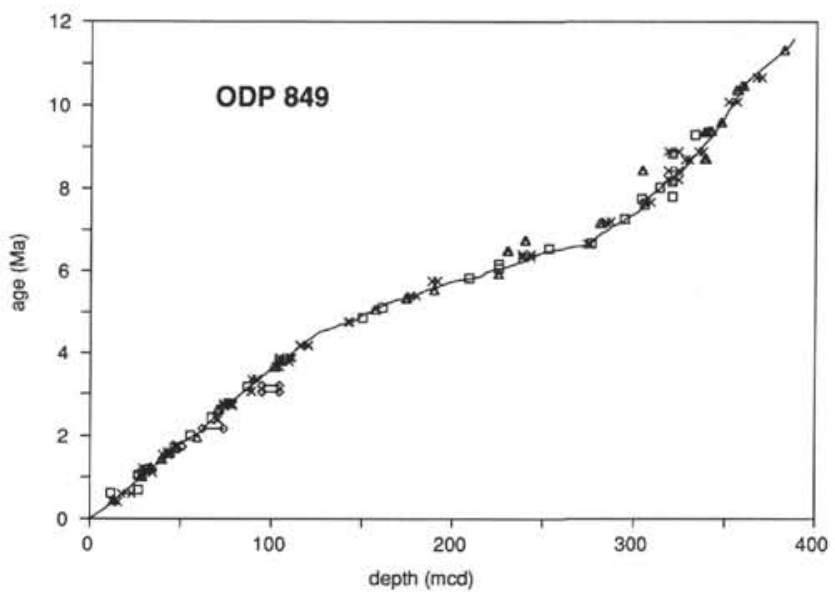

Figure 8. As in Figure 3, for Site 849. Symbols as in Figure 3.

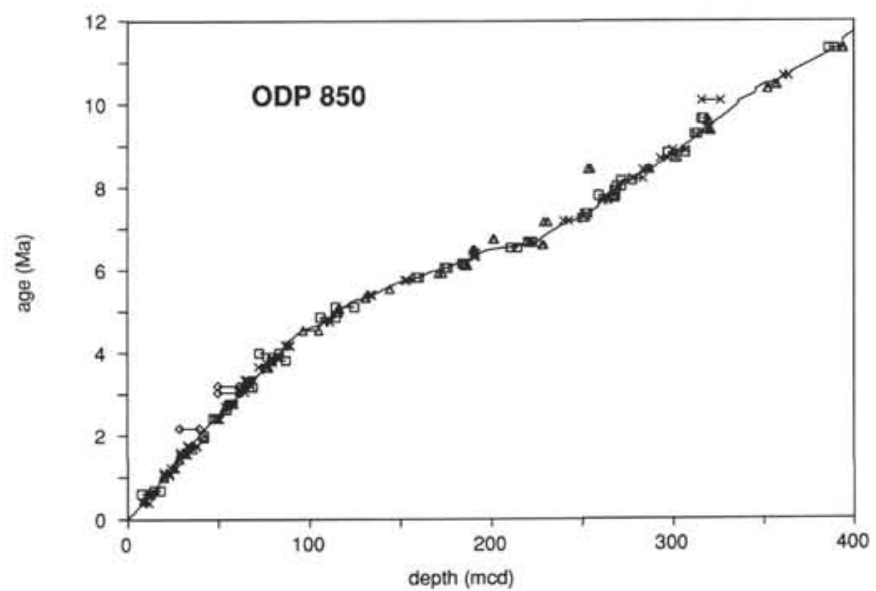

Figure 9. As in Figure 3, for Site 850. Symbols as in Figure 3. 


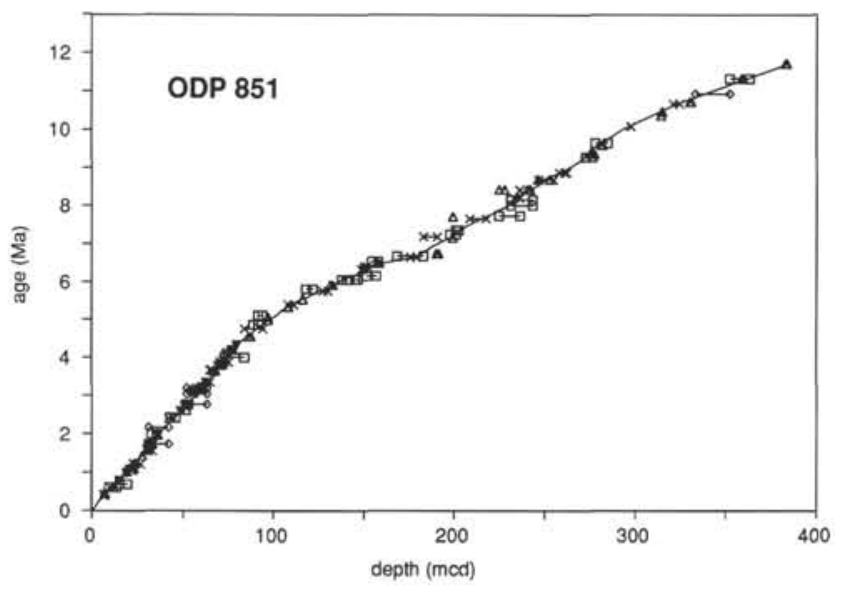

Figure 10. As in Figure 3, for Site 851. Symbols as in Figure 3.

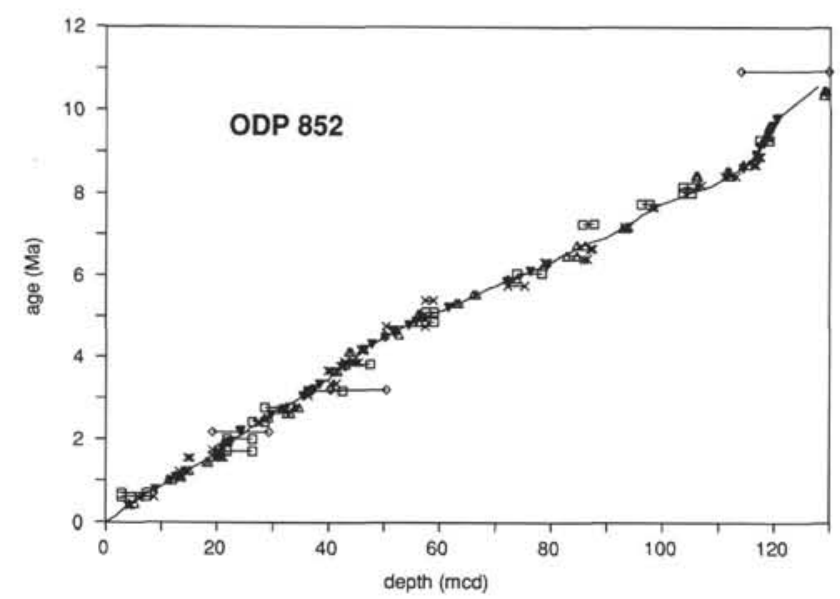

Figure 11. As in Figure 3, for Site 852. Symbols as in Figure 3.

sites were examined at wide intervals for some microfossil groups; it seems clear that a datum is more readily mislocated if only scattered samples are examined. Fourth, because judgment is required to decide whether a species is "present" or "absent," it may be that the criteria used were not optimal, or that they were not applied uniformly. Finally, the age models that we have used may not be sufficiently accurate.

The column labeled "Uncertainty" in Table 7 indicates those datums that do appear to be diachronous, although it is difficult to devise an objective means for doing this. For the radiolarians, Moore et al. (1993) showed that in the majority of cases, the diachrony is mappable and probably represents true ecological diachrony. Where this is not yet clear, we have indicated a query. In some cases, a reexamination of the material may indicate that the datum is not, in fact, diachronous, either because the age model is insufficiently precise or because the datum was mislocated. Of course, a datum may be functionally diachronous as a result of the species concerned being susceptible to dissolution or overgrowth, or simply being difficult to identify, even if its spread or demise were not spatially diachronous. Thus, a large estimate of raw diachrony in the "Best" column should be taken as a caution for that datum, regardless of its cause.

We have compared the diachrony of the datums for the various microfossil groups, separating first appearance datums (FADs) from last appearance datums (LADs). The data suggest that no significant difference exists between the reliability of FADs and LADs. However, it is difficult to devise objective means for eliminating less

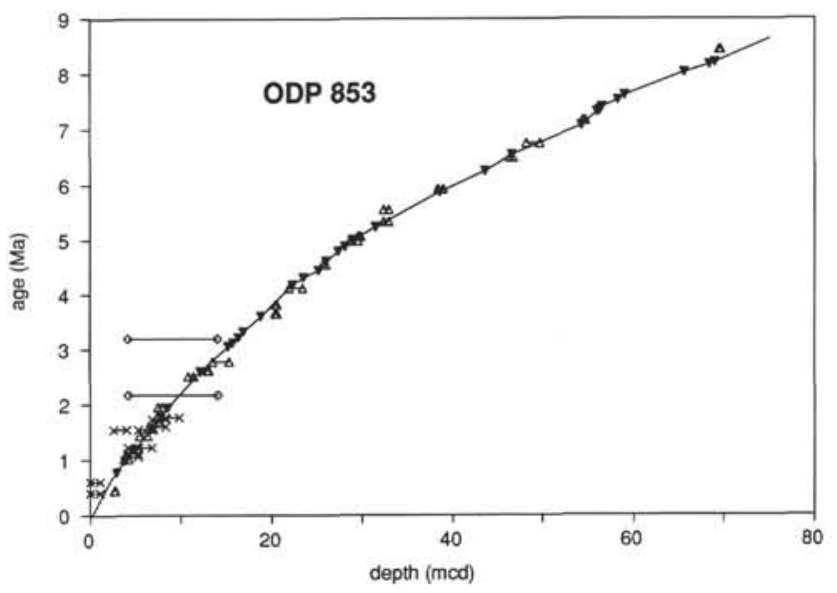

Figure 12. As in Figure 3, for Site 853. Symbols as in Figure 3, except for the deletion of diatoms (open squares).

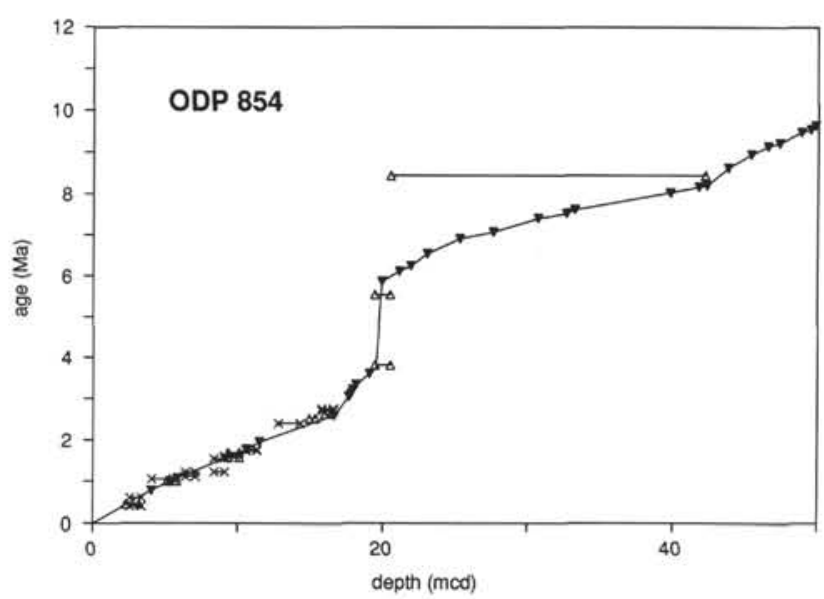

Figure 13. As in Figure 3, for Site 854. Symbols as in Figure 3, except for the deletion of diatoms (open squares) and foraminifers (open diamonds).

reliable observations in a way that is valid for all fossil groups, so that it is not easy to assess the relative quality of biostratigraphic datums from different microfossil groups, except in a very general sense. In addition, one should devise a means of assessing diachrony that is applicable to all groups. Finally, each biostratigrapher had different objectives in recording the information summarized here, and there was not time to examine all datums in all sites with equal care. For these reasons, we have not tabulated these comparisons.

Another approach to the evaluation of datum levels is to examine the distribution of estimates in individual sites for the age of each datum. Here, one has to take into account the fact that not all datums were examined in equal depth resolution. In general, datums were examined at high resolution subject to the constraints of preservation on the one hand, and to the time available on the other; if poor preservation is the reason a datum was not constrained closely, it is obvious that the observation is of less value. However, experience shows that observations of the position of datums that are made hastily aboard ship in core-catcher samples frequently require revision. For this reason, we have divided the 988 observations tabulated into those that are constrained within $0.21 \mathrm{~m}$.y. or closer ( 786 observations) and the rest (202 observations). In Table 8 , the data for the "well-defined" datums and the remainder are summarized. We found that the well-defined nannofossil datums were examined on average to within $0.05 \mathrm{Ma}$ and that the radiolarians and diatoms were exam- 
ined to within 0.08 and $0.09 \mathrm{Ma}$, respectively. We have estimated the deviation of each of these individual datum age estimates from the best value for that datum. The mean deviation of all nannofossil determinations from the best value is about $0.09 \mathrm{Ma}$; the equivalent figure for diatoms is $0.09 \mathrm{Ma}$, and for radiolarians, $0.15 \mathrm{Ma}$. For the whole data set and for all microfossil groups, the mean deviation is 0.39 ; taking the poorly constrained determinations only, the value is 0.50 . If the observation for less well-constrained datums were no less reliable, one might expect the mean deviation to approximate half the constraining range; the fact that the figure is far greater supports our initial assumption that the reliability of a biostratigraphic datum determination deteriorates more than proportionately if the observations have been too widely spaced. In the context of ODP work, this finding strongly supports the strategy of refining the placement of each datum in a single hole at a site, rather than covering each hole in less detail. The summary in Table 8 suggests that the resolution within which a datum is defined is absolutely critical; it may well be that many of the datums that are indicated as possibly diachronous in Table 7 may prove synchronous on closer examination.

It is not clear from Table 8 whether one can define the level of refinement beyond which the law of diminishing returns sets it. At first sight, it appears that this point was passed in the case of the nannofossils. On the other hand, one may note that the reentry of medium-sized Gephyrocapsa spp., examined at all 11 sites, shows an overall raw diachrony of only $0.01 \mathrm{Ma}$. This figure must be so low partly because of the chance that it is close to a magnetic reversal, so that at the sites in which the GRAPE age model would be expected to be less reliable, magnetostratigraphy fills the gap. However, the fact remains that this datum is clearly applicable with a remarkably high degree of precision. It may be that many other datums could be defined with equal precision. It may also be the case that in parts of our records, the age models could now be rendered more reliable by introducing biostratigraphic constraints. One remarkable feature of the Leg 138 work is that it was possible to develop a set of age models that did not contain biostratigraphical constraints, which provided an unusual opportunity to evaluate the reliability of the methods that are generally used. This does not mean that the age models are not amenable to further improvement.

To summarize the extent to which the Leg 138 calibrations may affect the biostratigraphic time scale, we show in Figure 14 the differences between our calibrations and those in use aboard ship, excluding those that we have characterized in Table 8 as being diachronous and excluding the interval older than $14 \mathrm{Ma}$ that is far from our primary magnetostratigraphic control. Figure 14 shows that, for the Pliocene, the ages of all the reliable biostratigraphic datums were already known with respect to the polarity time scale to within $0.2 \mathrm{Ma}$; our new calibrations are probably really significant only for the diatoms. However, in the Miocene section, it seems clear that there were significant uncertainties in the ages of a number of important datums and that the Leg 138 calibrations have reduced those uncertainties.

\section{CONCLUSIONS}

The sediments recovered during Leg 138 have provided us an opportunity to obtain an internally consistent set of age estimates for biostratigraphic datums from the main microfossil groups used in marine biostratigraphy. For the time interval from $13.25 \mathrm{Ma}$ to the present, these estimates are calibrated to the magnetic reversal scale and are tabulated in terms of the polarity time scale developed by Shackleton et al. (this volume) as well as for two other scales (BKF85; Cande and Kent, 1992). Although only a small number of datums are demonstrably synchronous over the area studied to better than 0.1 $\mathrm{Ma}$, more intensive work on these sequences will probably increase that number. The estimates given in Table 6 probably constitute the most homogeneous set of biostratigraphic datum ages that is at present available for the Neogene.
Table 5. Placement of biostratigraphic datums in Leg 138 sites.

\begin{tabular}{|c|c|c|c|c|c|}
\hline & $\begin{array}{l}\text { Biostratigraphic } \\
\text { datum }\end{array}$ & $\begin{array}{l}\text { Limit of } \\
\text { placement }\end{array}$ & $\begin{array}{l}\text { Age } \\
\text { (Ma) }\end{array}$ & $\begin{array}{l}\text { Type of } \\
\text { datum }\end{array}$ & $\begin{array}{c}\text { Site of } \\
\text { observation }\end{array}$ \\
\hline $\mathrm{t}$ & Nitzschia reinholdii & $t$ & 0.28 & D & 852 \\
\hline $\mathrm{t}$ & Nitzschia reinholdii & $\mathrm{t}$ & 0.36 & D & 849 \\
\hline $\mathrm{t}$ & Nitzschia reinholdii & $t$ & 0.38 & D & 847 \\
\hline t & Nitzschia reinholdii & $\mathrm{t}$ & 0.55 & D & 848 \\
\hline $\mathrm{t}$ & Nitzschia reinholdii & $t$ & 0.57 & D & 846 \\
\hline $\mathrm{t}$ & Nitzschia reinholdii & $\mathrm{t}$ & 0.57 & D & 851 \\
\hline $\mathrm{t}$ & Nitzschia reinholdii & $t$ & 0.96 & D & 845 \\
\hline $\mathrm{t}$ & Nitzschia reinholdii & o & 0.45 & D & 847 \\
\hline $\mathrm{t}$ & Nitzschia reinholdii & 0 & 0.63 & $\mathrm{D}$ & 850 \\
\hline$t$ & Nitzschia reinholdii & 0 & 0.63 & D & 846 \\
\hline $\mathrm{t}$ & Nitzschia reinholdii & o & 0.67 & D & 852 \\
\hline $\mathrm{t}$ & Nitzschia reinholdii & o & 0.70 & D & 851 \\
\hline$t$ & Nitzschia reinholdii & 0 & 0.77 & D & 848 \\
\hline $\mathrm{t}$ & Nitzschia reinholdii & o & 0.94 & D & 849 \\
\hline$t$ & Nitzschia reinholdii & o & 1.05 & D & 845 \\
\hline $\mathrm{t}$ & Nitzschia fossilis & $t$ & 0.09 & D & 844 \\
\hline$t$ & Nitzschia fossilis & $t$ & 0.28 & D & 852 \\
\hline$t$ & Nitzschia fossilis & $t$ & 0.49 & D & 847 \\
\hline $\mathrm{t}$ & Nitzschia fossilis & $t$ & 0.55 & D & 848 \\
\hline$t$ & Nitzschia fossilis & $t$ & 0.63 & D & 846 \\
\hline$t$ & Nitzschia fossilis & $\mathrm{t}$ & 0.71 & D & 850 \\
\hline$t$ & Nitzschia fossilis & $t$ & 0.79 & D & 851 \\
\hline $\mathrm{t}$ & Nitzschia fossilis & $t$ & 0.86 & D & 845 \\
\hline$t$ & Nitzschia fossilis & $t$ & 0.94 & D & 849 \\
\hline $\mathrm{t}$ & Nitzschia fossilis & o & 0.18 & D & 844 \\
\hline$t$ & Nitzschia fossilis & o & 0.64 & D & 847 \\
\hline$t$ & Nitzschia fossilis & o & 0.67 & D & 852 \\
\hline $\mathrm{t}$ & Nitzschia fossilis & 0 & 0.72 & D & 846 \\
\hline $\mathrm{t}$ & Nitzschia fossilis & 0 & 0.77 & D & 848 \\
\hline$t$ & Nitzschia fossilis & 0 & 0.90 & D & 850 \\
\hline$t$ & Nitzschia fossilis & o & 1.01 & D & 845 \\
\hline $\mathrm{t}$ & Nitzschia fossilis & 0 & 1.05 & D & 851 \\
\hline $\mathrm{t}$ & Nitzschia fossilis & 0 & 1.11 & D & 849 \\
\hline $\mathrm{t}$ & Rhizosolenia matuyama & $\mathrm{t}$ & 0.92 & D & 846 \\
\hline $\mathrm{t}$ & Rhizosolenia matuyama & t & 0.94 & D & 849 \\
\hline$t$ & Rhizosolenia matuyama & $\mathrm{t}$ & 1.01 & D & 845 \\
\hline $\mathrm{t}$ & Rhizosolenia matuyama & o & 1.08 & D & 846 \\
\hline $\mathrm{t}$ & Rhizosolenia matuyama & o & 1.09 & D & 845 \\
\hline $\mathrm{t}$ & Rhizosolenia matuyama & o & 1.11 & D & 849 \\
\hline b & Rhizosolenia matuyama & $t$ & 1.09 & D & 845 \\
\hline b & Rhizosolenia matuyama & $t$ & 1.11 & D & 849 \\
\hline b & Rhizosolenia matuyama & $t$ & 1.39 & D & 846 \\
\hline b & Rhizosolenia matuyama & o & 1.16 & D & 845 \\
\hline b & Rhizosolenia matuyama & o & 1.24 & D & 849 \\
\hline b & Rhizosolenia matuyama & o & 1.40 & D & 846 \\
\hline$t$ & $R$. praebergonii var. robusta & $t$ & 1.58 & D & 848 \\
\hline$t$ & R. praebergonii var, robusta & $t$ & 1.66 & D & 847 \\
\hline t & R. praebergonii var, robusta & $t$ & 1.66 & D & 851 \\
\hline $\mathrm{t}$ & R. praebergonii var. robusta & $\mathrm{t}$ & 1.70 & D & 849 \\
\hline$t$ & R. praebergonii var, robusta & $\mathrm{t}$ & 1.86 & D & 846 \\
\hline $\mathrm{t}$ & R. praebergonii var, robusta & $\mathrm{t}$ & 1.87 & D & 852 \\
\hline $\mathrm{t}$ & R. praebergonii var. robusta & o & 1.71 & D & 847 \\
\hline$t$ & R. praebergonii var, robusta & o & 1.74 & D & 849 \\
\hline t & R. praebergonii var, robusta & o & 1.75 & D & 848 \\
\hline $\mathrm{t}$ & R. praebergonii var. robusta & o & 1.75 & D & 851 \\
\hline $\mathrm{t}$ & R. praebergonii var. robusta & o & 1.87 & D & 846 \\
\hline$t$ & R. praebergonii var. robusta & o & 2.30 & D & 852 \\
\hline b & Pseudoeunotia doliolus & $\mathrm{t}$ & 1.63 & D & 844 \\
\hline b & Pseudoeunotia doliolus & $t$ & 1.74 & D & 845 \\
\hline b & Pseudoeunotia doliolus & $\mathrm{t}$ & 1.75 & D & 851 \\
\hline b & Pseudoeunotia doliolus & $\mathrm{t}$ & 1.87 & D & 852 \\
\hline b & Pseudoeunotia doliolus & $t$ & 1.96 & D & 849 \\
\hline b & Pseudoeunotia doliolus & $\mathrm{t}$ & 1.98 & D & 846 \\
\hline b & Pseudoeunotia doliolus & $\mathrm{t}$ & 2.03 & D & 847 \\
\hline b & Pseudoeunotia doliolus & $\mathrm{t}$ & 2.05 & D & 848 \\
\hline b & Pseudoeunotia doliolus & 1 & 2.13 & D & 850 \\
\hline$b$ & Pseudoeunotia doliolus & o & 1.80 & D & 845 \\
\hline b & Pseudoeunotia doliolus & o & 1.92 & D & 851 \\
\hline b & Pseudoeunotia doliolus & o & 2.00 & D & 846 \\
\hline b & Pseudoeunotia doliolus & o & 2.05 & D & 849 \\
\hline b & Pseudoeunotia doliolus & o & 2.06 & D & 847 \\
\hline b & Psendoeunotia doliolus & o & 2.07 & D & 848 \\
\hline b & Pseudoeunotia doliolus & o & 2.11 & D & 844 \\
\hline b & Pseudoeunotia doliolus & 0 & 2.14 & D & 850 \\
\hline
\end{tabular}

Notes: In the column labeled "Biostratigraphic datum," $t=$ top of range, $b=$ base of range, $t c=$ top of common occurrence, and $b c=$ bottom of common occurrence. In the column labeled "Age," $\mathrm{t}=$ the upper limit of the placement of the datum, and $\mathrm{o}$ $=$ the lower limit. In the column labeled "Type of datum," D = diatom (from Baldauf and Iwai, this volume), $\mathrm{F}=$ foraminifer (from Vincent and Toumarkine, this volume; from the site chapters in Mayer, Pisias, Janecek et al., 1992; or from Shackleton et al., this volume), $\mathrm{N}=$ nannofossil (Raffi and Flores, this volume), and $\mathrm{R}=$ radiolarian (Moore, this volume).

Only the first page of this table is reproduced here. The entire table appears on the CD-ROM (back pocket). 
Table 6. Estimates for ages of datums (see text for details).

\begin{tabular}{|c|c|c|c|c|c|c|c|c|c|}
\hline & & Med. & Dif. & Mid. & Diac. & Best & Unc. & Choice & Type \\
\hline b & Emiliania huxleyi & 0.12 & 0.04 & 0.12 & -0.04 & 0.26 & & Lit & $\mathrm{N}$ \\
\hline $\mathrm{t}$ & Stylatractus universus & 0.44 & 0.10 & 0.39 & 0.23 & 0.41 & & Lit & $\mathrm{R}$ \\
\hline $\mathrm{t}$ & Pseudoemiliania lacunosa & 0.45 & 0.06 & 0.58 & 0.30 & 0.46 & & Lit & $\mathrm{N}$ \\
\hline b & Collosphaera tuberosa & 0.61 & 0.08 & 0.45 & 0.36 & 0.61 & 0.08 & Median & $\mathrm{R}$ \\
\hline t & Nitzschia reinholdii & 0.62 & 0.14 & 0.71 & 0.51 & 0.62 & 0.14 & Median & D \\
\hline $\mathrm{t}$ & Globorotalia tosaensis & 0.63 & 0.35 & 0.63 & -0.35 & 0.59 & & Lit & $\mathrm{F}$ \\
\hline t & Nitzschia fossilis & 0.70 & 0.14 & 0.56 & 0.76 & 0.70 & 0.14 & Median & D \\
\hline b & Reentrance medium Gephyrocapsa spp. & 1.01 & 0.06 & 1.02 & 0.01 & 1.02 & 0.01 & Mid & $\mathrm{N}$ \\
\hline $\mathrm{t}$ & Pulleniatina left-coiling & 1.04 & 0.36 & 1.04 & -0.36 & 0.84 & & Lit & $\mathrm{F}$ \\
\hline $\mathrm{t}$ & Rhizosolenia matuyama & 1.02 & 0.15 & 1.05 & -0.07 & 1.05 & -0.07 & Mid & D \\
\hline t & Lamprocyrtis neoheteroporos & 1.06 & 0.07 & 1.07 & 0.08 & 1.06 & 0.07 & Median & $\mathrm{R}$ \\
\hline$t$ & Anthocyrtidium angulare & 1.12 & 0.06 & 1.13 & 0.10 & 1.12 & 0.06 & Median & $\mathrm{R}$ \\
\hline b & Rhizosolenia matuyama & 1.18 & 0.13 & 1.28 & 0.23 & 1.18 & 0.13 & Median & D \\
\hline $\mathrm{t}$ & Theocorythium vefulum & 1.21 & 0.11 & 1.22 & 0.06 & 1.22 & 0.06 & Mid & $\mathrm{R}$ \\
\hline b & Lamprocyrtis nigriniae & 1.23 & 0.08 & 1.33 & 0.22 & 1.23 & 0.08 & Median & $\mathrm{R}$ \\
\hline$t$ & Large Gephyrocapsa spp. & 1.24 & 0.05 & 1.22 & 0.06 & 1.24 & 0.05 & Median & $\mathrm{N}$ \\
\hline b & Large Gephyrocapsa spp. & 1.44 & 0.06 & 1.45 & 0.22 & 1.44 & 0.06 & Median & $\mathrm{N}$ \\
\hline b & Pterocorys minithorax & 1.55 & 0.11 & 1.40 & 0.71 & 1.55 & 0.11 & Median & $\mathrm{R}$ \\
\hline b & Theocorythium trachelium & 1.55 & 0.16 & 1.64 & 0.24 & 1.55 & 0.16 & Median & $\mathrm{R}$ \\
\hline$t$ & Calcidiscus macintyrei & 1.58 & 0.04 & 1.58 & 0.18 & 1.58 & 0.04 & Median & $\mathrm{N}$ \\
\hline $\mathrm{t}$ & Lamprocyrtis heteroporos & 1.61 & 0.10 & 1.80 & 0.55 & 1.61 & 0.10 & Median & $\mathrm{R}$ \\
\hline b & Medium Gephyrocapsa spp. & 1.69 & 0.04 & 1.71 & 0.20 & 1.69 & 0.04 & Median & $\mathrm{N}$ \\
\hline $\mathrm{t}$ & R. praebergonii var. robusta & 1.72 & 0.07 & 1.79 & 0.16 & 1.72 & 0.07 & Median & D \\
\hline t & Pterocanium prismatium & 1.74 & 0.09 & 1.74 & 0.06 & 1.74 & 0.06 & Mid & $\mathrm{R}$ \\
\hline$t$ & Globigerinoides fistulosus & 1.77 & 0.14 & 1.79 & 0.09 & 1.74 & 0.01 & 846 & $\mathrm{~F}$ \\
\hline b & Anthocyrtidium angulare & 1.77 & 0.07 & 1.83 & 0.15 & 1.77 & 0.07 & Median & $\mathbf{R}$ \\
\hline b & Pseudoeunotia doliolus & 2.01 & 0.10 & 1.97 & 0.33 & 2.01 & 0.10 & Median & D \\
\hline$t$ & Discoaster brouweri & 2.04 & 0.06 & 1.97 & 0.36 & 1.96 & & Lit & $\mathrm{N}$ \\
\hline$t$ & Globorotalia limbata & 2.10 & 0.80 & 2.17 & 0.32 & 2.18 & 0.00 & 846 & $\mathrm{~F}$ \\
\hline b & Globorotalia truncatulinoides & 2.39 & 0.12 & 2.39 & -0.12 & 2.39 & -0.12 & & $\mathrm{~F}$ \\
\hline $\mathrm{t}$ & Anthocyrtidium jenghisi & 2.40 & 0.10 & 2.39 & 0.18 & 2.40 & 0.10 & Median & $\mathbf{R}$ \\
\hline$t$ & Thalassiosira convexa & 2.43 & 0.13 & 2.67 & 1.06 & 2.43 & 0.13 & Median & D \\
\hline$t$ & Discoaster pentaradiatus & 2.52 & 0.06 & 2.50 & 0.14 & 2.52 & 0.06 & Median & $\mathrm{N}$ \\
\hline $\mathrm{t}$ & Discoaster surculus & 2.63 & 0.05 & 2.73 & 0.39 & 2.63 & 0.05 & Median & $\mathrm{N}$ \\
\hline b & Theocalyptra davisiana & 2.71 & 0.13 & 2.67 & 0.15 & 2.71 & 0.13 & Median & $\mathrm{R}$ \\
\hline$t$ & Stichocorys peregrina & 2.76 & 0.09 & 2.73 & 0.27 & 2.76 & 0.09 & Median & $\mathrm{R}$ \\
\hline$t$ & Discoaster tamalis & 2.78 & 0.04 & 2.86 & 0.20 & 2.78 & 0.04 & Median & $\mathrm{N}$ \\
\hline$t$ & Globigerinoides obliquus & 2.85 & 0.48 & 2.78 & -0.04 & 2.78 & -0.04 & Mid & $\mathrm{F}$ \\
\hline $\mathrm{t}$ & Nitzschia jouseae & 2.79 & 0.11 & 2.78 & 0.04 & 2.78 & 0.04 & Mid & D \\
\hline $\mathrm{t}$ & Globoquadrina altispira & 3.06 & 0.31 & 3.20 & 0.44 & 3.05 & 0.01 & 846 & $\mathrm{~F}$ \\
\hline b & Lamprocyrtis neoheteroporos & 3.06 & 0.15 & 2.99 & 0.86 & 3.06 & 0.15 & Median & $\mathrm{R}$ \\
\hline b & Lamprocyrtis heteroporos & 3.06 & 0.16 & 2.96 & 0.79 & 3.06 & 0.16 & Median & $\mathrm{R}$ \\
\hline b & Rhizosolenia praebergonii & 3.18 & 0.08 & 3.12 & 0.27 & 3.18 & 0.08 & Median & D \\
\hline$t$ & Sphaeroidinellopsis seminulina & 3.44 & 0.26 & 3.22 & 0.68 & 3.20 & 0.01 & 846 & $\mathrm{~F}$ \\
\hline$t$ & Anthocyrtidium pliocenica & 3.36 & 0.18 & 3.39 & 0.41 & 3.36 & 0.18 & Median & $\mathrm{R}$ \\
\hline$t$ & Sphenolithus spp. & 3.66 & 0.05 & 3.75 & 0.25 & 3.66 & 0.05 & Median & $\mathrm{N}$ \\
\hline$t$ & Phormostichoartus fistula & 3.67 & 0.02 & 4.35 & 1.67 & 3.67 & 0.02 & Median & $\mathrm{R}$ \\
\hline $\mathrm{t}$ & Lychnodictyum audax & 3.78 & 0.06 & 3.84 & 0.31 & 3.78 & 0.06 & Median & $\ddot{R}$ \\
\hline$t$ & Reticulofenestra pseudoumbilicus & 3.82 & 0.05 & 3.83 & 0.08 & 3.82 & 0.05 & Median & $\mathrm{N}$ \\
\hline b & Thalassiosira convexa f. convexa & 3.85 & 0.13 & 3.83 & 0.03 & 3.83 & 0.03 & Mid & D \\
\hline b & Amphirhopalum ypsilon & 3.88 & 0.14 & 3.82 & 0.36 & 3.88 & 0.14 & Median & $\mathrm{R}$ \\
\hline$t$ & Phormostichoartus dolium & 3.89 & 0.15 & 3.89 & 0.41 & 3.89 & 0.15 & Median & $\mathrm{R}$ \\
\hline b & Asteromphalus elegans & 4.07 & 0.70 & 4.01 & 0.04 & 4.01 & 0.04 & Mid & $\mathrm{D}$ \\
\hline bc & Discoaster asymmetricus & 4.13 & 0.09 & 4.20 & 0.54 & 4.13 & 0.09 & Median & $\mathrm{N}$ \\
\hline b & Spongaster tetras & 4.17 & 0.12 & 4.05 & 0.31 & 4.17 & 0.12 & Median & $\mathbf{R}$ \\
\hline$t$ & Didymocyrtis penultima & 4.20 & 0.14 & 4.45 & 0.59 & 4.20 & 0.14 & Median & $\mathrm{R}$ \\
\hline $\mathrm{t}$ & Pulleniatina spectabilis & 4.23 & 0.21 & 4.33 & 0.00 & 4.33 & 0.00 & 846 & $\mathrm{~F}$ \\
\hline $\mathrm{t}$ & Amaurolithus primus & 4.56 & 0.10 & 4.54 & 0.13 & 4.56 & 0.10 & Median & $\mathrm{N}$ \\
\hline b & Pterocanium prismatium & 4.76 & 0.07 & 4.34 & 0.99 & 4.76 & 0.07 & Median & $\mathrm{R}$ \\
\hline$t$ & Nitzschia cylindrica & 4.87 & 0.15 & 4.84 & 0.31 & 4.87 & 0.15 & Median & $\mathrm{D}$ \\
\hline$t$ & Ceratolithus acutus & 4.99 & 0.06 & 5.19 & 0.50 & 4.99 & 0.06 & Median & $\mathrm{N}$ \\
\hline b & Ceratolithus rugosus & 5.07 & 0.02 & 5.09 & 0.30 & 5.07 & 0.02 & Median & $\mathrm{N}$ \\
\hline b & Nitzschia jouseae & 5.12 & 0.25 & 5.05 & 0.34 & 5.12 & 0.25 & Median & D \\
\hline b & Ceratolithus acutus & 5.34 & 0.02 & 5.35 & 0.03 & 5.34 & 0.02 & Median & $\mathrm{N}$ \\
\hline $\mathrm{t}$ & Triquetrorhabdulus rugosus & 5.35 & 0.01 & 5.35 & -0.01 & 5.35 & -0.01 & & $\mathrm{~N}$ \\
\hline $\mathrm{t}$ & Solenosphaera omnitubus & 5.40 & 0.05 & 5.27 & 0.56 & 5.40 & 0.05 & Median & $\mathbf{R}$ \\
\hline $\mathrm{t}$ & Globoquadrina dehiscens & 5.49 & 0.00 & 5.49 & 0.00 & 5.49 & 0.00 & & $\mathrm{~F}$ \\
\hline $\mathrm{t}$ & Discoaster quinqueramus & 5.55 & 0.02 & 5.52 & 0.29 & 5.55 & 0.02 & Median & $\mathrm{N}$ \\
\hline b & Globorotalia tumida & 5.59 & 0.54 & 6.42 & 1.73 & 5.59 & 0.54 & Median & $\mathrm{F}$ \\
\hline b & Thalassiosira oestrupii & 5.63 & 0.04 & 5.65 & 0.31 & 5.63 & 0.04 & Median & D \\
\hline $\mathrm{t}$ & Siphostichartus corona & 5.76 & 0.01 & 6.28 & 1.56 & 5.76 & 0.01 & Median & $\mathrm{R}$ \\
\hline$t$ & Thalassiosira miocenica & 5.83 & 0.03 & 5.80 & 0.40 & 5.83 & 0.03 & Median & D \\
\hline $\mathrm{t}$ & Amaurolithus amplificus & 5.93 & 0.05 & 5.97 & 0.16 & 5.93 & 0.05 & Median & $\mathrm{N}$ \\
\hline $\mathrm{t}$ & Nitzschia miocenica & 6.07 & 0.04 & 5.97 & 0.27 & 6.07 & 0.04 & Median & D \\
\hline $\mathrm{t}$ & N. miocenica var. elongata & 6.08 & 0.05 & 6.10 & 0.19 & 6.08 & 0.05 & Median & D \\
\hline$t$ & Circular reticulofenestrids & 6.12 & 0.02 & 6.12 & 0.21 & 6.12 & 0.02 & Median & $\mathrm{N}$ \\
\hline$t$ & Thalassiosira praeconvexa & 6.17 & 0.19 & 6.20 & 0.25 & 6.17 & 0.19 & Median & D \\
\hline 1 & Stichocorys johnsoni & 6.34 & 0.07 & 6.35 & 0.16 & 6.34 & 0.07 & Median & $\mathbf{R}$ \\
\hline $\mathrm{t}$ & Calocycletta caepa & 6.42 & 0.21 & 6.61 & 0.75 & 6.42 & 0.21 & Median & $\mathrm{R}$ \\
\hline b & Amaurolithus amplificus & 6.50 & 0.02 & 6.37 & 0.49 & 6.50 & 0.02 & Median & $\mathrm{N}$ \\
\hline$t$ & Rossiella praepaleacea & 6.52 & 0.12 & 6.52 & -0.12 & 6.52 & -0.12 & Mid & D \\
\hline b & Thalassiosira miocenica & 6.54 & 0.08 & 6.53 & 0.10 & 6.54 & 0.08 & Median & D \\
\hline b & T. convexa var. aspinosa & 6.57 & 0.13 & 6.55 & 0.06 & 6.55 & 0.06 & Mid & D \\
\hline b & Circular reticulofenestrids & 6.62 & 0.05 & 6.63 & 0.33 & 6.62 & 0.05 & Median & $\mathrm{N}$ \\
\hline b & Stichocorys delmontensis to $S$, peregrina & 6.66 & 0.05 & 6.70 & 0.25 & 6.66 & 0.05 & Median & $\mathrm{R}$ \\
\hline b & Thalassiosira praeconvexa & 6.73 & 0.16 & 6.69 & 0.05 & 6.69 & 0.05 & Mid & D \\
\hline $\mathrm{t}$ & Absence Reticulofenestra pseudoumbilicus & 6.76 & 0.04 & 6.65 & 0.78 & 6.76 & 0.04 & Median & $\mathrm{N}$ \\
\hline
\end{tabular}


Table 6 (continued).

\begin{tabular}{|c|c|c|c|c|c|c|c|c|c|}
\hline & & Med. & Dif. & Mid. & Diac. & Best & Unc. & Choice & Type \\
\hline t & Nitzschia porteri & 7.14 & 0.02 & 7.14 & -0.02 & 7.14 & -0.02 & & D \\
\hline b & Amaurolithus primus & 7.17 & 0.12 & 7.10 & 0.44 & 7.17 & 0.12 & Median & $\mathrm{N}$ \\
\hline b & Solenosphaera omnitubus & 7.20 & 0.15 & 7.14 & 0.25 & 7.20 & 0.15 & Median & $\mathrm{R}$ \\
\hline b & Nitzschia miocenica & 7.27 & 0.11 & 7.09 & 0.49 & 7.27 & 0.11 & Median & D \\
\hline$t$ & Rossiella paleacea & 7.36 & 0.05 & 7.37 & 0.05 & 7.37 & 0.05 & Median & \\
\hline b & Nitzschia reinholdii & 7.64 & 0.23 & 7.61 & -0.08 & 7.61 & -0.08 & Mid & D \\
\hline t & Diartus hughesi & 7.65 & 0.09 & 7.67 & 0.08 & 7.67 & 0.08 & Mid & $\mathrm{R}$ \\
\hline 1 & Minylitha convallis & 7.73 & 0.05 & 7.74 & 1.01 & 7.73 & 0.05 & Median & $\mathrm{N}$ \\
\hline$t$ & A. ellipticus var. javanicus & 7.75 & 0.15 & 7.74 & 0.30 & 7.75 & 0.15 & Median & D \\
\hline $\mathbf{t}$ & Thalassiosira burckliana & 7.81 & 0.31 & 7.81 & -0.31 & 7.81 & -0.31 & Mid & D \\
\hline b & Nitzschia marina & 7.92 & 0.09 & 7.92 & -0.09 & 7.92 & -0.09 & & D \\
\hline b & Nitzschia cylindrica & 8.03 & 0.07 & 8.08 & 0.22 & 8.03 & 0.07 & Median & D \\
\hline$t$ & Thalassiosira yabei & 8.17 & 0.19 & 8.06 & 0.42 & 8.17 & 0.19 & Median & D \\
\hline$t$ & Botryostrobus miralestensis & 8.21 & 0.10 & 8.24 & 0.26 & 8.21 & 0.10 & Median & $\mathrm{R}$ \\
\hline 1 & Diartus pettersoni & 8.43 & 0.13 & 8.45 & 0.28 & 8.43 & 0.13 & Median & $\mathrm{R}$ \\
\hline b & Discoaster berggrenii & 8.07 & 0.15 & 7.94 & 1.04 & 8.45 & & Mag & $\mathrm{N}$ \\
\hline b & Discoaster loeblichii & 8.45 & 0.06 & 8.49 & 0.13 & 8.45 & 0.06 & Median & $N$ \\
\hline b & Discoaster pentaradiatus & 8.46 & 0.07 & 8.45 & 0.01 & 8.55 & & Mag & $\mathrm{N}$ \\
\hline b & Diartus pettersoni to D. hughesi & 8.70 & 0.17 & 8.76 & 0.27 & 8.70 & 0.17 & Median & $\mathrm{R}$ \\
\hline b & Absence $R$. pseudoumbilicus & 8.71 & 0.15 & 8.83 & 0.46 & 8.71 & 0.15 & Median & $\mathrm{N}$ \\
\hline$t$ & Coscinodiscus loeblichii & 8.79 & 0.29 & 8.79 & -0.29 & 8.79 & -0.29 & & D \\
\hline b & Thalassiosira burckliana & 8.84 & 0.29 & 8.84 & -0.19 & 8.84 & -0.19 & Mid & D \\
\hline b & Diartus hughesi & 8.89 & 0.10 & 8.77 & 0.83 & 8.89 & 0.10 & Median & $\mathrm{R}$ \\
\hline $\mathrm{t}$ & Stichocorys wolffi & 8.89 & 0.13 & 8.98 & 0.26 & 8.89 & 0.13 & Median & $\mathbf{R}$ \\
\hline$t$ & Denticulopsis simonsenii & 9.35 & 0.30 & 9.59 & 0.65 & 9.35 & 0.30 & Median & D \\
\hline b & Minylitha convallis & 9.37 & 0.06 & 9.31 & 0.38 & 9.37 & 0.06 & Median & $\mathrm{N}$ \\
\hline$t$ & Discoaster hamatus & 9.40 & 0.03 & 9.51 & 0.51 & 9.40 & 0.03 & Median & $N$ \\
\hline b & Discoaster neohamatus & 9.52 & 0.04 & 9.57 & 0.18 & 9.52 & 0.04 & Median & $\mathrm{N}$ \\
\hline b & Coscinodiscus loeblichii & 9.55 & 1.24 & 9.55 & -1.24 & 9.55 & -1.24 & & D \\
\hline $\mathrm{t}$ & Discoaster neohamatus & 9.60 & 0.12 & 9.60 & -0.12 & 9.60 & -0.12 & Mid & $\mathrm{N}$ \\
\hline$t$ & Actinocyclus moronensis & 9.66 & 0.19 & 9.84 & 0.87 & 9.66 & 0.19 & Median & D \\
\hline$t$ & Cyrtocapsella japonica & 10.09 & 0.12 & 10.09 & 0.07 & 10.09 & 0.07 & Mid & $\mathrm{R}$ \\
\hline$t$ & Lithoperta thornburgi & 10.09 & 0.17 & 10.54 & 1.74 & 10.09 & 0.17 & Median & $\mathbf{R}$ \\
\hline$t$ & A. ellipticus $\mathrm{f}$. lanceolata & 10.35 & 0.81 & 10.35 & -0.81 & 10.35 & -0.81 & & D \\
\hline b & Discoaster hamatus & 10.38 & 0.08 & 10.57 & 0.60 & 10.38 & 0.08 & Median* & $\mathrm{N}$ \\
\hline$t$ & Coccolithus miopelagicus & 10.48 & 0.04 & 10.60 & 0.56 & 10.48 & 0.04 & Median* & $\mathrm{N}$ \\
\hline$t$ & Carpocanopsis cristata & 10.68 & 0.07 & 10.65 & 0.26 & 10.68 & 0.07 & Median & $\mathrm{R}$ \\
\hline b & Catinaster coalinus & 10.73 & 0.04 & 10.79 & 0.13 & 10.73 & 0.04 & Median & $\mathrm{N}$ \\
\hline b & Globorotalia siakensis & 10.47 & 1.41 & 10.94 & -0.03 & 10.94 & -0.03 & Mid & $\mathrm{F}$ \\
\hline$t$ & Coscinodiscus gigas var. diorama & 11.10 & 0.15 & 11.13 & -0.07 & 11.13 & -0.07 & Mid & D \\
\hline b & R. paleacea var. elongata & 11.13 & 0.07 & 11.13 & -0.07 & 11.13 & -0.07 & Mid & D \\
\hline$t$ & Craspedodiscus coscinodiscus & 11.34 & 0.20 & 11.28 & 0.23 & 11.34 & 0.20 & Median & D \\
\hline tc & Discoaster kugleri & 11.36 & 0.03 & 11.47 & 0.27 & 11.34 & -0.02 & 845 & $\mathrm{~N}$ \\
\hline$t$ & Synedra jouseana & 11.41 & 0.32 & 11.41 & -0.32 & 11.41 & -0.32 & & D \\
\hline b & Sphaeroidinella subdehiscens & 11.74 & 0.33 & 11.74 & -0.33 & 11.74 & -0.33 & Mid & $\mathrm{F}$ \\
\hline bc & Discoaster kugleri & 11.81 & 0.06 & 12.06 & 0.67 & 11.74 & -0.02 & 845 & $\mathrm{~N}$ \\
\hline$t$ & Lithoperta renzae & 11.79 & 0.05 & 11.82 & 0.01 & 11.82 & 0.01 & Mid & $\mathrm{R}$ \\
\hline$t$ & Cyrtocapsella cornuta & 11.83 & 0.03 & 11.86 & 0.08 & 11.83 & 0.03 & Median & R \\
\hline $\mathrm{t}$ & Dorcadospyris alata & 11.86 & 0.05 & 11.86 & -0.03 & 11.86 & -0.03 & Mid & $\mathbf{R}$ \\
\hline b & Diartus pettersoni & 11.86 & 0.08 & 12.42 & 1.16 & 11.86 & 0.08 & Median & $\mathrm{R}$ \\
\hline $\mathrm{t}$ & Actinocyclus ingens & 12.10 & 0.10 & 12.17 & 0.10 & 12.10 & 0.10 & Median & D \\
\hline $\mathrm{t}$ & Coronocyclus nitescens & 12.43 & 0.03 & 12.73 & 1.20 & 12.12 & -0.02 & 845 & $\mathrm{~N}$ \\
\hline b & Calcidiscus macintyrei & 12.14 & 0.01 & 12.14 & -0.01 & 12.14 & -0.01 & & $\mathrm{~N}$ \\
\hline $\mathrm{t}$ & Cestodiscus pulchellus & 12.08 & 0.45 & 12.14 & 0.17 & 12.14 & 0.17 & Mid & D \\
\hline b & Thalassiosira brunii & 12.28 & 0.18 & 12.19 & 0.06 & 12.19 & 0.06 & Mid & D \\
\hline b & Discoaster kugleri & 12.40 & 0.02 & 12.71 & 1.14 & 12.20 & -0.02 & 845 & $\mathrm{~N}$ \\
\hline b & Nitzschia porteri & 12.23 & 0.16 & 12.23 & -0.16 & 12.23 & -0.16 & & D \\
\hline b & Cyrtocapsella japonica & 12.40 & 0.09 & 12.39 & 0.08 & 12.39 & 0.08 & Mid & $\mathbf{R}$ \\
\hline 12 & Annellus californicus & 12.45 & 0.24 & 12.45 & -0.24 & 12.45 & -0.24 & & D \\
\hline b & Triquetrorhabdulus rugosus & 12.81 & 0.03 & 12.82 & 0.27 & 12.62 & -0.03 & 845 & $\mathrm{~N}$ \\
\hline$t$ & Calcidiscus premacintyrei & 12.51 & 0.04 & 12.51 & 0.50 & 12.65 & -0.03 & 845 & $\mathrm{~N}$ \\
\hline $\mathrm{t}$ & Coscinodiscus lewisianus & 12.97 & 0.17 & 12.86 & 0.12 & 12.86 & 0.12 & Mid & D \\
\hline b & Globorotalia fohsi lobata & 12.94 & 0.23 & 12.94 & -0.23 & 12.94 & -0.23 & Mid & $\mathrm{F}$ \\
\hline b & Coscinodiscus gigas var. diorama & 13.00 & 0.05 & 13.00 & -0.05 & 13.00 & -0.05 & & D \\
\hline t & Discoaster signus & 13.08 & 0.07 & 13.08 & -0.07 & 13.08 & -0.07 & & $\mathrm{~N}$ \\
\hline $\mathrm{t}$ & Cyclicargolithus floridanus & 13.46 & 0.25 & 13.38 & 0.36 & 13.19 & -0.02 & 845 & $\mathrm{~N}$ \\
\hline $\mathrm{t}$ & Thalassiosira tappanae & 13.20 & 0.29 & 13.20 & -0.29 & 13.20 & -0.29 & & D \\
\hline b & Lithoperta thornburgi & 13.32 & 0.05 & 13.33 & 0.55 & 13.32 & 0.05 & Median & $\mathrm{R}$ \\
\hline b & Triceratium cinnamoneum & 13.32 & 0.27 & 13.32 & -0.27 & 13.32 & -0.27 & & D \\
\hline b & Calocycletta caepa & 13.35 & 0.08 & 13.35 & 0.32 & 13.35 & 0.08 & Median & $\mathrm{R}$ \\
\hline b & Denticulopsis simonsenii & 13.47 & 0.26 & 13.47 & $-0,26$ & 13.47 & -0.26 & Mid & D \\
\hline$t$ & Sphenolithus heteromorphus & 13.95 & 0.21 & 13.95 & 0.18 & 13.57 & -0.02 & 845 & $\mathrm{~N}$ \\
\hline $\mathrm{t}$ & Stichocorys armata & 13.74 & 0.09 & 13.72 & 0.09 & 13.72 & 0.09 & Median & $\mathrm{R}$ \\
\hline b & Reticulofenestra pseudoumbilicus & 13.95 & 0.21 & 13.95 & 0.18 & 13.95 & 0.18 & Mid & $\mathrm{N}$ \\
\hline $\mathrm{t}$ & Cestodiscus peplum & 14.32 & 0.87 & 14.03 & 0.26 & 14.03 & 0.26 & Mid & D \\
\hline b & Actinocyclus ellipticus & 14.04 & 0.27 & 14.04 & -0.27 & 14.04 & -0.27 & & D \\
\hline 1 & Globorotalia archaeomenardii & 14.04 & 0.27 & 14.04 & -0.27 & 14.04 & -0.27 & Mid & $\mathrm{F}$ \\
\hline b & Globorotalia fohsi group & 14.04 & 0.27 & 14.04 & -0.27 & 14.04 & -0.27 & Mid & $\mathrm{F}$ \\
\hline b & Coscinodiscus blysmos & 14.34 & 0.33 & 14.34 & -0.33 & 14.34 & -0.33 & & D \\
\hline $\mathrm{t}$ & Liriospyrys parkarae & 14.43 & 0.26 & 14.46 & -0.09 & 14.46 & -0.09 & Mid & $\mathbf{R}$ \\
\hline$t$ & Acrocubus octopyle & 14.47 & 0.27 & 14.55 & -0.10 & 14.55 & -0.10 & Mid & $\mathrm{R}$ \\
\hline $\mathrm{t}$ & Carpocanopsis bramlettei & 14.67 & 0.28 & 14.75 & 0.27 & 14.75 & 0.27 & Mid & $\mathrm{R}$ \\
\hline $\mathrm{tl}$ & Anellus californicus & 14.89 & 0.26 & 14.89 & -0.26 & 15.0 & & Lit & D \\
\hline b & Orbulina suturalis & 14.89 & 0.26 & 14.89 & -0.26 & 14.89 & -0.26 & & $\mathrm{~F}$ \\
\hline $\mathrm{t}$ & Calocycletta costata & 15.12 & 0.06 & 15.11 & 0.12 & 15.12 & 0.06 & Median & $\mathbf{R}$ \\
\hline b & Actinocyclus ingens & 15.36 & 0.23 & 15.36 & -0.23 & 15.5 & & Lit & D \\
\hline $\mathrm{t}$ & Coscinodiscus lewisianus var. similis & 15.57 & 0.19 & 15.57 & -0.19 & 15.7 & & Lit & D \\
\hline
\end{tabular}


Table 6 (continued).

\begin{tabular}{|c|c|c|c|c|c|c|c|c|c|}
\hline & & Med. & Dif. & Mid. & Diac. & Best & Unc. & Choice & Type \\
\hline b & Dorcadospyris dentata to $D$, alata & 15.69 & 0.05 & 15.71 & 0.28 & 15.69 & 0.05 & Median & $\mathbf{R}$ \\
\hline $\mathrm{t}$ & Liriospyris stauropora & $15.8 \mathrm{I}$ & 0.06 & 15.84 & 0.13 & 15.81 & 0.06 & Median & $\mathrm{R}$ \\
\hline b & Liriospyris parkerae & 15.82 & 0.06 & 15.85 & 0.15 & 15.82 & 0.06 & Median & $\mathbf{R}$ \\
\hline$t$ & Helicosphaera ampliaperta & 15.85 & 0.12 & 15.87 & 0.06 & 15.87 & 0.06 & Mid & $\mathrm{N}$ \\
\hline$t$ & Eucyrtidium diaphenes & 15.95 & 0.05 & 15.97 & 0.09 & 15.95 & 0.05 & Median & $\mathrm{R}$ \\
\hline b & Carpocanopsis bramlettei & 16.08 & 0.05 & 16.08 & -0.05 & 16.08 & -0.05 & Mid & $\mathbf{R}$ \\
\hline b & Discoaster signus & 16.21 & 0.03 & 16.20 & 0.00 & 16.20 & 0.00 & Midpoint & $\dddot{N}$ \\
\hline $\mathrm{t}$ & Acme Discoaster deflandrei & 16.22 & 0.03 & 16.22 & -0.03 & 16.22 & -0.03 & & $\mathrm{~N}$ \\
\hline b & Cestodiscus peplum & 16.43 & 0.20 & 16.41 & -0.08 & 16.4 & & Lit & D \\
\hline$t$ & Carpocanopsis cingulata & 16.44 & 0.04 & 16.42 & 0.12 & 16.44 & 0.04 & Median & $\mathrm{R}$ \\
\hline$t$ & Raphidodiscus marylandicus & 16.49 & 0.23 & 16.49 & -0.23 & 16.49 & -0.23 & & $\mathrm{D}$ \\
\hline $\mathrm{t}$ & Thalassiosira fraga & 16.49 & 0.23 & 16.49 & -0.23 & 16.49 & -0.23 & & D \\
\hline b & Praeorbulina sicana & 16.50 & 0.25 & 16.50 & -0.25 & 16.50 & -0.25 & & $\mathrm{~F}$ \\
\hline b & Giraffospyris toxaria & 16.55 & 0.07 & 16.59 & -0.07 & 16.59 & -0.07 & Mid & $\mathbf{R}$ \\
\hline $\mathrm{b}$ & Acrocubus octopyle & 16.59 & 0.13 & 16.54 & 0.17 & 16.59 & 0.13 & Median & $\ddot{\mathrm{R}}$ \\
\hline$t$ & Didymocyrtis prismatica & 16.68 & 0.09 & 16.65 & 0.43 & 16.68 & 0.09 & Median & $\ddot{R}$ \\
\hline
\end{tabular}

Notes: In Column $1, t=t o p: b=$ base; reent = reentry of the species; circ $=$ circular. Med. $=$ datum age based on the median of ages which define the upper and the low limits of the datum. Dif. = difference between these medians. Mid. $=$ age at the midpoint between the youngest estimate of the estimates of the lower limit and the oldest of the estimates of the upper limit of the datum. Diac. $=$ diachrony (i.e., the amount by which the oldest of the estimates of the upper limit exceeds the youngest of the estimates of the lower limit); if the figure in this column is negative, the data are fully consistent with a synchronous datum. Best $=$ our best estimate of the datum age. Unc. $=$ measure of the uncertainty in this estimate, generally from Diac. columns. Choice = whether the best estimate is based on the median (Median), on the midpoint (Mid), or if it is estimated on another basis (an asterisk indicates that a discrepant estimate was ignored; a blank implies that the two estimates are identical; a site number indicates that the estimate is based on that site only: Mag implies that the estimate is based on the sites with magnetostratigraphy; Lit implies that the best estimate is from the published literature). Type $=$ the microfossil type, with $\mathrm{D}=$ diatom, $\mathrm{F}=$ foraminifer, $\mathrm{N}=$ nannofossil, and $\mathrm{R}=$ radiolarian.

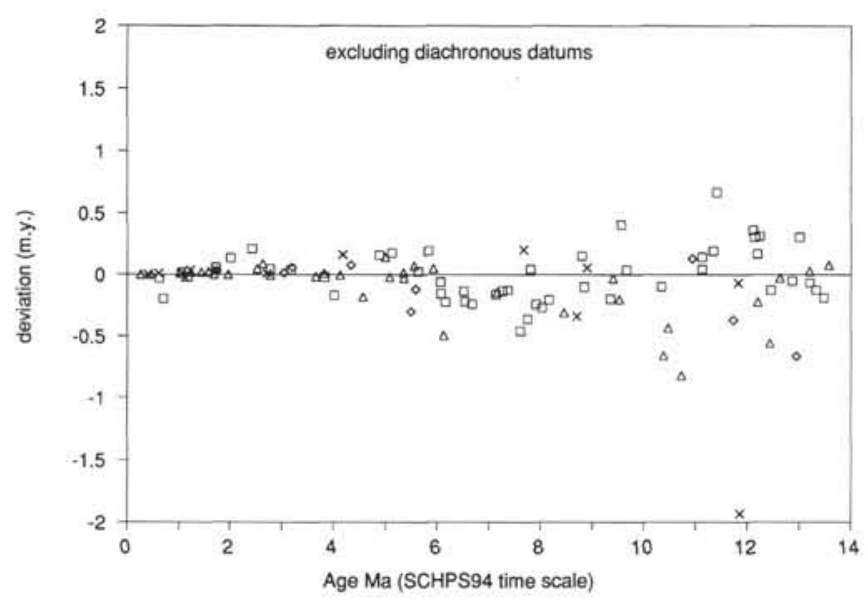

Figure 14. Differences between literature ages (Shipboard Scientific Party, 1992; largely based on, or intended to be consistent with, Berggren et al. $1985 \mathrm{~b})$ and ages estimated here but recalculated in terms of the magnetic polarity time scale used by Berggren et al. (1985a). Differences for datums shown in Table 7 as diachrons have not been plotted. Only the interval to 14 $\mathrm{Ma}$, in which we have primary magnetostratigraphic control, is shown. Symbols as in Figure 1.

In general, the reliability with which biostratigraphic datum planes are located improves disproportionately as they are examined in more detail. At a site with several holes, effort should be devoted to covering one hole carefully, rather than several holes in a cursory fashion. When time is a constraint, it is probably more valuable to determine a few datums carefully, instead of determining many with less attention.

\section{ACKNOWLEDGMENTS}

We thank the crew of the JOIDES Resolution for enabling Leg 138 to return with such a magnificent legacy of material, and our colleagues aboard ship for sharing nine weeks of exciting hard work for the benefit of a generation of Pacific-loving paleoceanographers. We thank Alan Mix and June Wilson for counting rare specimens of
Globigerinoides fistulosus at our request. Simon Crowhurst and Jenni Tokens devoted a great deal of effort to the completion of the manuscript. This work was supported by NERC under Grant GST/554. We are grateful to Jan Backman, John Barron, and Ken Miller for reviewing the manuscript and contributing a great deal to its improvement.

\section{REFERENCES ${ }^{*}$}

Backman, J., Schneider, D.A., Rio, D., and Okada, H., 1990. Neogene lowlatitude magnetostratigraphy from Site 710 and revised age estimates of Miocene nannofossil datum events. In Duncan, R.A., Backman, J., Peterson, L.C., et al., Proc. ODP, Sci. Results, 115: College Station, TX (Ocean Drilling Program), 271-276.

Backman, J., and Shackleton, N.J., 1983. Quantitative biochronology of Pliocene and early Pleistocene calcareous nannofossils from the Atlantic, Indian and Pacific oceans. Mar. Micropaleontol., 8:141-170.

Baksi, A.K., 1992. A ${ }^{40} \mathrm{Ar} /{ }^{39} \mathrm{Ar}$ age for the termination of Chron 5: a new calibration point for the Miocene section of the GPTS. Eos, 27 October 1992, 630. (Abstract)

Baksi, A.J., Hoffman, K.A., and Farrar, E., 1993. A new calibration point for the Late Miocene section of the geomagnetic polarity time scale: ${ }^{40} \mathrm{Ar}{ }^{39} \mathrm{Ar}$ dating of lava flows from Akaroa Volcano, New Zealand. Geophys. Res. Lett., 20:667-670.

Barron, J.A., Keller, G., and Dunn, D.A., 1985a. A multiple microfossil biochronology for the Miocene. In Kennett, J.P. (Ed.), The Miocene Ocean: Paleoceanography and Biogeography. Mem.-Geol. Soc. Am., 163:21-36.

Barron, J., Nigrini, C.A., Pujos, A., Saito, T., Theyer, F., Thomas, E., and Weinrich, N., 1985b. Synthesis of biostratigraphy, central Equatorial Pacific, Deep Sea Drilling Project Leg 85: refinement of Oligocene to Quaternary biochronology. In Mayer, L., Theyer, F., Thomas, E., et al., Init. Repts. DSDP, 85: Washington (U.S. Govt. Printing Office), 905-934.

Berggren, W.A., Kent, D.V., and Flynn, J.J., 1985a. Jurassic to Paleogene: Part 2. Paleogene geochronology and chronostratigraphy. In Snelling, N.J. (Ed.), The Chronology of the Geological Record. Geol. Soc. London Mem., 10:141-195.

Berggren, W.A., Kent, D.V., and Van Couvering, J.A., 1985b. The Neogene: Part 2. Neogene geochronology and chronostratigraphy. In Snelling, N.J. (Ed.), The Chronology of the Geological Record. Geol. Soc. London Mem., 10:211-260.

\footnotetext{
Abbreviations for names of organizations and publication titles in ODP reference lists follow the style given in Chemical Abstracts Service Source Index (published by American Chemical Society).
} 
Burckle, L.H., 1978. Early Miocene to Pliocene diatom datum level for the equatorial Pacific. Proc. Second Working Group Mtg. Biostratigraphic. Datum Planes Pacific Neogene, IGCP Proj. 114. Spec. Publ., Geol. Res. Dev. Ctr. 1:25-44.

Cande, S.C., and Kent, D.V., 1992. A new geomagnetic polarity time scale for the Late Cretaceous and Cenozoic. J. Geophys. Res., 97:13917-13951.

Hays, J.D., and Shackleton, N.J., 1976. Globally synchronous extinction of the radiolarian Stylatractus universus. Geology, 4:649-652.

Hilgen, F.J., 1991a. Astronomical calibration of Gauss to Matuyama sapropels in the Mediterranean and implication for the Geomagnetic Polarity Time Scale. Earth Planet. Sci. Lett., 104:226-244.

1991b. Extension of the astronomically calibrated (polarity) time scale to the Miocene/Pliocene boundary. Earth Planet. Sci. Lett., 107:349368.

Johnson, D.A., and Nigrini, C.A., 1985. Synchronous and time-transgressive Neogene radiolarian datum levels in the equatorial Indian and Pacific Oceans. Mar. Micropaleontol., 9:489-523.

Mayer, L.A., Pisias, N.G., Janecek, T.R., et al., 1992. Proc. ODP, Init. Repts., 138 (Pts. 1 and 2): College Station, TX (Ocean Drilling Program).

Moore, T.C., Jr., Shackleton, N.J., and Pisias, N.G., 1993. Paleoceanography and the diachrony of radiolarian events in the eastern equatorial Pacific. Paleoceanography, 8:567-586.

Morley, J.J., and Shackleton, N.J., 1979. Extension of the radiolarian Stylatractus universus as a biostratigraphic datum to the Atlantic Ocean. Geology, 6:309-311.
Olafsson, G., 1991. Quantitative calcareous nannofossil biostratigraphy and biochronology of early through late Miocene sediments from DSDP Hole 608. Medd. Stockholms Univ. Inst. Geol. Geochem., 285.

Pisias, N.G., Barron, J.A., Nigrini, C.A., and Dunn, D.A., 1985. Stratigraphic resolution of Leg 85 drill sites: an initial analysis. In Mayer, L., Theyer, F., Thomas, E., et al., Init. Repts. DSDP, 85: Washington (U.S. Govt. Printing Office), 695-708.

Rio, D., Fornaciari, E., and Raffi, I., 1990. Late Oligocene through early Pleistocene calcareous nannofossils from western equatorial Indian Ocean (Leg 115). In Duncan, R.A., Backman, J., Peterson, L.C., et al., Proc. ODP, Sci. Results, 115: College Station, TX (Ocean Drilling Program), 175-235. Shipboard Scientific Party, 1992. Explanatory notes. In Mayer, L., Pisias, N., Janecek, T., et al., Proc. ODP, Init. Repts., 138 (Pt. 1): College Station, TX (Ocean Drilling Program), 13-42.

Thierstein, H.R., Geitzenauer, K., Molfino, B., and Shackleton, N.J., 1977. Global synchroneity of late Quaternary coccolith datum levels: validation by oxygen isotopes. Geology, 5:400-404.

Date of initial receipt: 5 October 1993

Date of acceptance: 11 March 1994

Ms 138SR-127 
Table 7. Best estimates for ages of biostratigraphic datums determined in Leg 138 sites.

\begin{tabular}{|c|c|c|c|c|c|c|}
\hline & SCHPS94 & CK92 & BKF85 & SSP92 & $\begin{array}{l}\text { Raw } \\
\text { dif. }\end{array}$ & $\begin{array}{l}\text { Adj } \\
\text { dif. }\end{array}$ \\
\hline $\mathrm{t}$ Nitzschia reinholdii & 0.62 & 0.62 & 0.62 & 0.65 & -0.03 & -0.03 \\
\hline t Nitzschia fossilis & 0.70 & 0.70 & 0.66 & 0.85 & -0.15 & -0.19 \\
\hline t Rhizosolenia matuyama & 1.05 & 1.03 & 0.96 & 0.94 & 0.11 & 0.02 \\
\hline b Rhizosolenia matuyama & 1.18 & 1.16 & 1.08 & 1.10 & 0.08 & -0.02 \\
\hline t $R$. pracbergonii var. robusta & 1.72 & 1.70 & 1.61 & 1.55 & 0.17 & 0.06 \\
\hline b Pseudoetunotia doliolus & 2.01 & 2.04 & 1.93 & 1.80 & 0.21 & 0.13 \\
\hline t Thalassiosira convexa & 2.43 & 2.43 & 2.31 & 2.10 & 0.33 & 0.21 \\
\hline t Nitzschia jouseae & 2.78 & 2.78 & 2.65 & 2.60 & 0.18 & 0.05 \\
\hline b Rhizosolenia praebergonii & 3.18 & 3.18 & 3.04 & 3.00 & 0.18 & 0.04 \\
\hline b Thalassiosira convexa f. convexa & 3.83 & 3.73 & 3.58 & 3.60 & 0.23 & -0.02 \\
\hline b Asteromphalus elegans & 4.01 & 3.89 & 3.73 & 3.90 & 0.11 & -0.17 \\
\hline t Nitzschia cylindrica & 4.87 & 4.69 & 4.46 & 4.30 & 0.57 & 0.16 \\
\hline b Nitzschia jouseae & 5.12 & 4.94 & 4.68 & 4.50 & 0.62 & 0.18 \\
\hline b Thalassiosira oestrupii & 5.63 & 5.45 & 5.13 & 5.10 & 0.53 & 0.03 \\
\hline t Thalassiosira miocenica & 5.83 & 5.64 & 5.30 & 5.10 & 0.73 & 0.20 \\
\hline t Nitzschia miocenica & 6.07 & 5.89 & 5.49 & 5.55 & 0.52 & -0.06 \\
\hline t N. miocenica var. elongata & 6.08 & 5.90 & 5.49 & 5.65 & 0.43 & -0.16 \\
\hline t Thalassiosira praeconvexa & 6.17 & 5.99 & 5.58 & 5.80 & 0.37 & -0.22 \\
\hline I Rossiella praepaleacea & 6.52 & 6.34 & 5.87 & 6.00 & 0.52 & -0.13 \\
\hline b Thalassiosira miocenica & 6.54 & 6.36 & 5.88 & 6.10 & 0.44 & -0.22 \\
\hline b $T$, convexa var. aspinosa & 6.55 & 6.37 & 5.89 & NA & NA & NA \\
\hline b Thalassiosira praeconvexa & 6.69 & 6.51 & 6.06 & 6.30 & 0.39 & -0.24 \\
\hline I Nitzschia porteri & 7.14 & 6.97 & 6.54 & 6.70 & 0.44 & -0.16 \\
\hline b Nitzschia miocenica & 7.27 & 7.10 & 6.62 & 6.75 & 0.52 & -0.13 \\
\hline I Rossiella paleacea & 7.37 & 7.20 & 6.68 & 6.80 & 0.57 & -0.12 \\
\hline b Nitzschia reinholdii & 7.61 & 7.46 & 6.84 & 7.30 & 0.31 & -0.46 \\
\hline I A. ellipticus var, javanicus & 7.75 & 7.60 & 6.99 & 7.35 & 0.40 & -0.36 \\
\hline I Thalassiosira burckliana & 7.81 & 7.66 & 7.05 & 7.00 & 0.81 & 0.05 \\
\hline b Nitzschia marina & 7.92 & 7.77 & 7.16 & 7.40 & 0.52 & -0.24 \\
\hline b Nitzschia cylindrica & 8.03 & 7.89 & 7.28 & 7.55 & 0.48 & -0.27 \\
\hline I Thalassiosira yabei & 8.17 & 8.04 & 7.35 & 7.55 & 0.61 & -0.20 \\
\hline t Coscinodiscus loeblichii & 8.79 & 8.69 & 8.05 & 7.90 & 0.89 & 0.15 \\
\hline b Thalassiosira burckliana & 8.84 & 8.74 & 8.10 & 8.20 & 0.64 & -0.10 \\
\hline t Denticulopsis simonsenii & 9.35 & 9.29 & 8.61 & 8.80 & 0.55 & -0.20 \\
\hline b Coscinodiscus loeblichii & 9.55 & 9.50 & 8.81 & 8.40 & 1.15 & 0.41 \\
\hline t Actinocyclus moronensis & 9.66 & 9.61 & 8.94 & 8.90 & 0.75 & 0.04 \\
\hline b A. ellipticus f. lanceolata & 10.35 & 10.32 & 9.80 & 9.90 & 0.44 & -0.10 \\
\hline I Coscinodiscus gigas v. diorama & 11.13 & 11.13 & 10.74 & 10.70 & 0.43 & 0.04 \\
\hline b $R$. paleacea var. elongata & 11.13 & 11.13 & 10.74 & 10.60 & 0.53 & 0.14 \\
\hline t Craspedodiscus coscinodiscus & 11.34 & 11.35 & 10.99 & 10.80 & 0.54 & 0.19 \\
\hline t Synedra jouseana & 11.41 & 11.42 & 11.07 & 10.40 & 1.01 & 0.67 \\
\hline t Actinocyclus ingens & 12.10 & 12.11 & 11.86 & 11.50 & 0.60 & 0.36 \\
\hline t Cestodiscus pulchellus & 12.14 & 12.15 & 11.91 & 11.60 & 0.54 & 0.31 \\
\hline b Thalassiosira brunii & 12.19 & 12.20 & 11.97 & 11.80 & 0.39 & 0.17 \\
\hline t Nitzschia porteri & 12.23 & 12.24 & 12.02 & 11.70 & 0.53 & 0.32 \\
\hline t2 Annellus californicus & 12.45 & 12.46 & 12.28 & 12.40 & 0.05 & -0.12 \\
\hline t Coscinodiscus lewisianus & 12.86 & 12.87 & 12.75 & 12.80 & 0.06 & -0.05 \\
\hline b Coscinodiscus gigas v. diorama & 13.00 & 13.01 & 12.91 & 12.60 & 0.40 & 0.31 \\
\hline I Thalassiosira tappanae & 13.20 & 13.21 & 13.14 & 13.20 & -0.00 & -0.06 \\
\hline b Triceratium cinnamoneum & 13.32 & 13.33 & 13.28 & 13.40 & -0.09 & -0.12 \\
\hline b Denticulopsis simonsenii & 13.47 & 13.48 & 13.46 & 13.65 & -0.18 & -0.19 \\
\hline t Cestodiscus peplum & 14.03 & 14.04 & 14.06 & 14.20 & -0.17 & -0.14 \\
\hline b Actinocyclus ellipticus & 14.04 & 14.04 & 14.06 & 14.40 & -0.37 & -0.34 \\
\hline b Coscinodiscus blysmos & 14.34 & 14.34 & 14.38 & 14.60 & -0.26 & -0.22 \\
\hline tI Anellus californicus & 15.00 & 15.00 & 15.08 & 15.00 & 0.00 & 0.08 \\
\hline b Actinocyclus ingens & 15.50 & 15.50 & 15.64 & 15.50 & 0.00 & 0.14 \\
\hline t Coscinodiscus lewisianus var. similis & 15.70 & 15.70 & 15.85 & 15.70 & 0.00 & 0.15 \\
\hline b Cestodiscus peplum & 16.40 & 16.40 & 16.61 & 16.40 & 0.00 & 0.21 \\
\hline t Thalassiosira fraga & 16.49 & 16.49 & 16.70 & 16.20 & 0.29 & 0.50 \\
\hline I Raphidodiscus marylandicus & 16.49 & 16.49 & 16.70 & 16.75 & -0.27 & -0.05 \\
\hline b Crucidenticula nicobarica & 18.12 & 18.12 & 18.05 & 17.80 & 0.32 & 0.25 \\
\hline b Crasepedodiscus coscinodiscus ss. & 18.12 & 18.12 & 18.05 & 17.30 & 0.82 & 0.75 \\
\hline t Globorotalia tosaensis & 0.59 & 0.59 & 0.59 & NA & NA & NA \\
\hline t Pulleniatina left & 0.84 & 0.84 & 0.78 & NA & NA & NA \\
\hline t Globigerinoides fistulosus & 1.74 & 1.73 & 1.63 & 1.60 & 0.14 & 0.03 \\
\hline t Globorotalia limbata & 2.18 & 2.20 & 2.09 & NA & NA & NA \\
\hline b Globorotalia truncatulinoides & 2.39 & 2.40 & 2.28 & 1.90 & 0.49 & $0.38^{*}$ \\
\hline t Globigerinoides obliquus & 2.78 & 2.78 & 2.65 & 1.80 & 0.98 & $0.85^{\mu}$ \\
\hline t Globoquadrina altispira & 3.05 & 3.05 & 2.92 & 2.90 & 0.15 & 0.02 \\
\hline t Sphaeroidinellopsis seminulina & 3.20 & 3.20 & 3.06 & 3.00 & 0.20 & 0.06 \\
\hline t Pulleniatina spectabilis & 4.33 & 4.14 & 3.98 & 3.90 & 0.43 & 0.08 \\
\hline t Globoquadrina dehiscens & 5.49 & 5.31 & 5.00 & 5.30 & 0.19 & -0.30 \\
\hline b Globorotalia tumida & 5.59 & 5.40 & 5.08 & 5.20 & 0.39 & -0.12 \\
\hline t Globorotalia siakensis & 10.94 & 10.93 & 10.53 & 10.40 & 0.53 & 0.13 \\
\hline b Sphaeroidinella subdehiscens & 11.74 & 11.74 & 11.43 & 11.80 & -0.07 & -0.37 \\
\hline b Globorotalia fohsi lobata & 12.94 & 12.95 & 12.84 & 13.50 & -0.57 & -0.66 \\
\hline t Globorotalia archaeomenardii & 14.04 & 14.04 & 14.06 & NA & NA & NA \\
\hline b Globorotalia fohsi group & 14.04 & 14.04 & 14.06 & 14.00 & 0.04 & 0.06 \\
\hline b Orbulina suturalis & 14.89 & 14.89 & 14.96 & 15.20 & -0.31 & -0.24 \\
\hline b Praeorbulina sicana & 16.50 & 16.50 & 16.71 & 16.30 & 0.20 & 0.41 \\
\hline b Emiliania huxleyi & 0.26 & 0.26 & 0.26 & 0.26 & 0.00 & 0.00 \\
\hline t Pseudoemiliania lacunosa & 0.46 & 0.46 & 0.46 & 0.46 & 0.00 & 0.00 \\
\hline b Reentry medium Gephyrocapsa spp. & 1.02 & 1.00 & 0.93 & 0.92 & 0.09 & 0.01 \\
\hline t Large Gephyrocapsa spp. & 1.24 & 1.22 & 1.14 & 1.12 & 0.12 & 0.02 \\
\hline b Large Gephyrocapsa spp. & 1.44 & 1.42 & 1.34 & 1.32 & 0.12 & 0.02 \\
\hline t Calcidiscus macintyrei & 1.58 & 1.56 & 1.48 & 1.45 & 0.13 & 0.03 \\
\hline
\end{tabular}


Table 7 (continued).

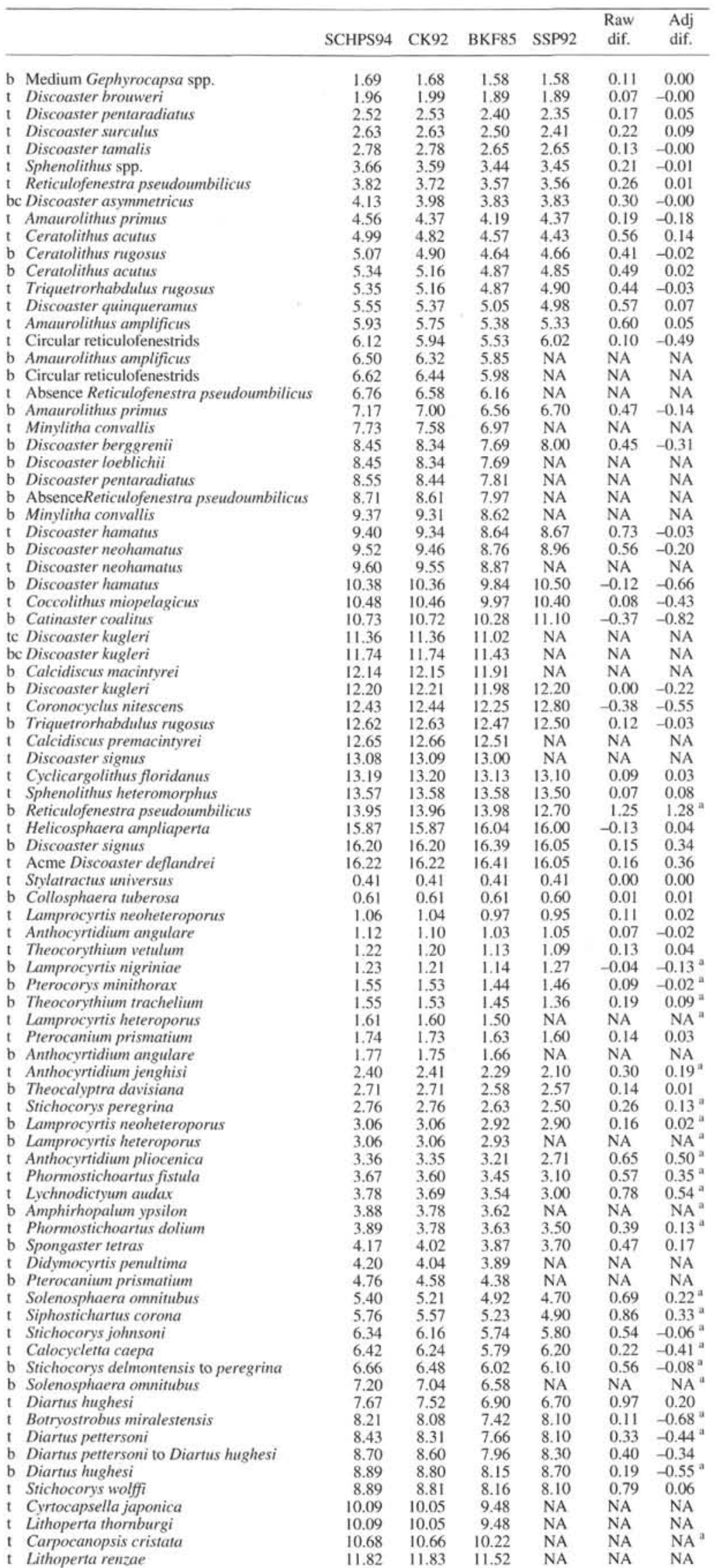


Table 7 (continued).

\begin{tabular}{llllllll}
\hline & SCHPS94 & CK92 & BKF85 & SSP92 & $\begin{array}{c}\text { Raw } \\
\text { dif. }\end{array}$ & $\begin{array}{c}\text { Adj } \\
\text { dif. }\end{array}$ \\
\hline t Cyrtocapsella cornuta & 11.83 & 11.84 & 11.53 & 11.60 & 0.23 & -0.07 \\
t Dorcadospyris alata & 11.86 & 11.87 & 11.57 & 13.50 & -1.65 & -1.93 \\
b Diartus pettersoni & 11.86 & 11.87 & 11.57 & 12.50 & -0.64 & -0.93 \\
b Cyrtocapsella japonica & 12.39 & 12.40 & 12.20 & NA & NA & NA \\
b Lithoperta thornburgi & 13.32 & 13.33 & 13.28 & NA & NA & NA \\
b Calocycletta caepa & 13.35 & 13.36 & 13.32 & NA & NA & NA \\
t Stichocorys armata & 13.72 & 13.72 & 13.74 & NA & NA & NA \\
t Liriospyrys parkarae & 14.46 & 14.46 & 14.50 & NA & NA & NA \\
t Acrocubus octopyle & 14.55 & 14.55 & 14.60 & NA & NA & NA \\
t Carpocanopsis bramlettei & 14.75 & 14.75 & 14.81 & NA & NA & NA \\
t Calocycletta costata & 15.12 & 15.12 & 15.22 & 15.00 & 0.12 & 0.22 \\
b Dorcadospyris dentata to D. alata & 15.69 & 15.69 & 15.84 & 16.70 & -1.01 & -0.86 \\
t Liriospyris stauropora & 15.81 & 15.81 & 15.97 & NA & NA & NA \\
b Liriospyris parkerae & 15.82 & 15.82 & 15.98 & NA & NA & NA \\
t Eucyrtidium diaphenes & 15.95 & 15.95 & 16.12 & NA & NA & NA \\
b Carpocanopsis bramlettei & 16.08 & 16.08 & 16.26 & NA & NA & NA \\
t Carpocanopsis cingulata & 16.44 & 16.44 & 16.65 & NA & NA & NA \\
b Giraffospyris toxaria & 16.59 & 16.59 & 16.81 & NA & NA & NA \\
b Acrocubus octopyle & 16.59 & 16.59 & 16.81 & NA & NA & NA \\
t Didymocyrtis prismatica & 16.68 & 16.68 & 16.90 & NA & NA & NA \\
\hline
\end{tabular}

Note; SCHPS94 = our estimate, based on the time scale of Shackleton et al. (this volume); CK92 = our estimate, calibrated back to the polarity time scale of Cande and Kent (1992): BKF85 = our estimate. calibrated back to the polarity time scale of Berggren et al. (1985a); SSP92 = age used by Shipboard Scientific Party (1992), based on Berggren et al. (1985b). Raw difference $=$ the difference between our estimate and that used by the Shipboard Scientific Party (1992). Adjusted difference $=$ the difference between our estimate recalibrated to BKF85, and that used by the Shipboard Scientific Party (1992). $t=$ top of range, and $b=$ bottom of range.

a This datum is probably significantly diachronous.

Table 8. Mean deviation of estimates from individual sites from calibration ages for those datums determined to $0.2 \mathrm{~m} . \mathrm{y}$. or better and for the remainder.

\begin{tabular}{lcc}
\hline \multicolumn{1}{c}{ Datum } & $\begin{array}{c}\text { Mean } \\
\text { deviation }\end{array}$ & $\begin{array}{c}\text { Mean } \\
\text { constraint }\end{array}$ \\
\hline Radiolarians & 0.15 & 0.08 \\
Nannofossils & 0.10 & 0.05 \\
Diatoms & 0.10 & 0.09 \\
All groups ${ }^{\mathrm{a}}$ & 0.39 & 0.25 \\
All groups $^{\mathrm{b}}$ & 0.50 & 0.55 \\
\hline
\end{tabular}

Notes: An insufficient number of foraminifer datums was determined for this comparison. The radiolarian, nannofossil, and diatom datums were constrained within 0.2 m.y. or better.

all groups, all data,

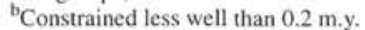

